\author{
UNIVERSIDADE DE SÃO PAULO \\ INSTITUTO DE RELAÇÕES INTERNACIONAIS
}

DANIELE OLIVEIRA GAVE

A RELAÇÃO ENTRE O FEDERAL RESERVE E O TESOURO ENTRE O AUGE DA CRISE FINANCEIRA GLOBAL E O IMPASSE EM TORNO DA ELEVAÇÃO DO TETO DA DÍVIDA, 2008-2011 


\section{A RELAÇÃO ENTRE O FEDERAL RESERVE E O TESOURO ENTRE O AUGE DA CRISE FINANCEIRA GLOBAL E $O$ IMPASSE EM TORNO DA ELEVAÇÃO DO TETO DA DÍVIDA, 2008-2011}

Dissertação apresentada ao Programa de Pós-Graduação em Relações Internacionais do Instituto de Relações Internacionais da Universidade de São Paulo, para a obtenção do título de Mestre em Ciências

Orientador(a): Profa. Dra. Maria Antonieta Del Tedesco Lins

Versão corrigida.

A versão original se encontra disponível na Biblioteca do Instituto de Relações Internacionais e na Biblioteca Digital de Teses e Dissertações da USP, documentos impresso e eletrônico. 
Autorizo a reprodução e divulgação total ou parcial deste trabalho, por qualquer meio convencional ou eletrônico, para fins de estudo e pesquisa, desde que citada a fonte.

Catalogação da Publicação

Instituto de Relações Internacionais da Universidade de São Paulo

Gave, Daniele Oliveira.

A Relação entre o Federal Reserve e o Tesouro entre o auge da Crise Financeira Global e o impasse em torno da elevação do teto da dívida, 2008-2011. / Daniele Oliveira Gave.; orientadora Profa. Dra. Maria Antonieta Del Tedesco Lins. - São Paulo, 2015.

105. p.

Dissertação (Mestrado) --Universidade de São Paulo, 2015.

1. Sistema Monetário Internacional. 2. Crise Financeira Global. 3. Federal Reserve. I. Lins, Maria Antonieta Del Tedesco. II. A Relação entre o Federal Reserve e o Tesouro entre o auge da Crise Financeira Global e o impasse em torno da elevação do teto da dívida, 2008-2011. 
Dedico este trabalho a Luís Fernando, pela ternura de sempre. 


\section{AGRADECIMENTOS}

A minha família e aos meus amigos Bruna Dinardi, Giovana Caldeira, Michelle Possenti, Juliana Costa e Rafael Terada, pela paciência e entusiasmo.

Aos colegas do GACINT e da pós-graduação, especialmente a Patrícia Tambourgi, Mariana Chaimovich, Mônica Sodré, Tamya Rebelo e Daniela Sampaio, por tornar essa jornada ainda mais interessante.

A minha orientadora, Tuca, pela atenção, colaboração e confiança.

Ao Instituto de Relações Internacionais, pela oportunidade de realizar este curso de mestrado.

À Fundação de Amparo à Pesquisa do Estado de São Paulo, pela concessão da bolsa de mestrado e pelo apoio financeiro para a realização desta pesquisa. 
Success is the ability to go from one failure to another with no loss of enthusiasm.

Winston Churchill 


\section{Resumo}

Esta pesquisa tem como objetivo analisar a mecânica dos processos políticos internos do Federal Reserve System e sua interação com o Departamento do Tesouro dos Estados Unidos no período entre o auge da crise financeira global no final de 2008 e o impasse sobre a elevação do teto da dívida pública em 2011. Foram analisados documentos oficias das duas instituições, bem como pronunciamentos de seus dirigentes. O estudo mostra que as estratégias desenhadas pelos formuladores de política monetária e fiscal convergiram durante a maior parte do período considerado, com a criação e implementação de variados instrumentos e programas de grande impacto. Nesse processo, o papel internacional do dólar foi reforçado.

Palavras-chave: Sistema Monetário Internacional, Crise Financeira Global, Federal Reserve, Departamento do Tesouro.

\section{Abstract}

This research aims at analyzing the mechanics of the internal political processes of the Federal Reserve System and its interaction with the U.S. Department of Treasury between the height of global financial crisis, late 2008, and the deadlock around the debt ceiling raise in 2011. To this end, the study was based on official documents issued by the two agencies and statements made by their representatives. The analysis indicates that the strategies designed by monetary and fiscal policymakers were complementary during most of the period in focus, through the creation and implementation of different policy tools and programs of great impact. In this process, the international role of the dollar was reinforced.

Keywords: International Monetary System, Global Financial Crisis, Federal Reserve, U.S. Department of the Treasury. 


\section{Lista de Tabelas}

Tabela 1 - Condição \& Posição Financeira do Governo dos Estados Unidos entre 2007-2011,

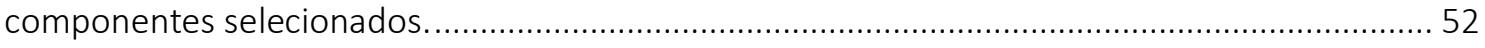

Tabela 2 - Dívida Bruta Federal do Governo dos Estados Unidos entre 2007-2011 ................... 69 Tabela 3 - Balanço do Federal Reserve System (FED) entre 2007-2011, componentes selecionados. 77

\section{Lista de Quadros}

Quadro 1 - Participantes do Federal Open Market Committee (FOMC), membros do Board e presidentes dos Federal Reserve Banks (FRBs)

Quadro 2 - Datas das reuniões oficiais e extraordinárias do Federal Open Market Committee (FOMC) 41

Quadro A-1 - Ações e decisões do Federal Reserve System (FED). 96

Quadro A-2 - Ações e decisões do Departamento do Tesouro dos Estados Unidos. 100

Quadro B-1 - Principais fatos e eventos entre o segundo semestre de 2008 e primeiro semestre de 2011. 105

\section{Lista de Abreviaturas e Siglas}

ABS Asset-backed securities ou títulos lastreados por ativos

ABCP Asset-backed commercial paper ou títulos lastreados por papéis comerciais

AIG American Insurance Group, Inc.

AIA AIA Group Limited

ALICO American Life Insurance Company

AMLF Asset-backed Commercial Paper Money Market Mutual Fund Liquidity Facility

ARRA American Recovery and Reinvestment Act

BHC Banking holding companies 
BOJ Bank of Japan ou Banco Central Japonês

Board Federal Reserve Board of Governors

CEO Chief Executive Officer

CDS Credit default swap

$\mathrm{CDCl}$ Community Development Capital Initiative

CMBS Commercial mortgage-backed securities ou títulos comerciais lastreados por hipotecas

CPFF Commercial Paper Funding Facility

Credit Card Act Credit Card Accountability Responsibility and Disclosure Act

ECB European Central Bank ou BCE, Banco Central Europeu

EESA Emergency Economic Stabilization Act

FAS Financial and Accounting Standards ou padrões financeiros e de contabilidade

FED Federal Reserve System

FDIC Federal Deposit Insurance Corporation

FHA Federal House Administration

FHFA Federal Housing Finance Agency

FRB Federal Reserve Bank

FRBNY Federal Reserve Bank of New York

FOMC Federal Open Market Committee ou Comitê

FY Fiscal Year ou ano fiscal

GDP Gross domestic product ou PIB, produto interno bruto

GAO Governmental Accountability Office

GSE Government-sponsored enterprise

Fannie Mae Federal National Mortgage Association

Freddie Mac Federal Home Loan Mortgage Corporation

FHLBs Federal Home Loan Banks 
HERA Housing and Economic Recovery Act

$\mathrm{H} 4 \mathrm{H} \quad$ Program HOPE for Homeowners

IORR Interest on required reserves rates ou juros pagos sobre reservas obrigatórias

IOER Interest on excess reserves rates ou juros pagos sobre reservas excedentes

Libor London interbank offered rate

LLC Limited liability company ou sociedade de responsabilidade limitada

MBS Mortgage-backed securities ou títulos lastreados por hipotecas

OIS Overnight index swap rate

OCC Office of the Comptroller of the Currency

OTS Office of Thrift Supervision

PCDF Primary Dealer Credit Facility

PWG President's Working Group on Financial Markets

repo Repurchase agreement ou acordo de recompra

RRP Reverse repurchase agreement

SCAP Supervisory Capital Assessment Program

SEP Summary of Economic Projections

SFP Supplementary Financing Program

SOMA System Open Market Account

SPV Special purpose vehicles ou veículos de propósito especial

TAF Term Auction Facility

TALF Term Asset-backed Securities Loan Facility

TARP Troubled Asset Relief Program

TLGP Temporary Liquidity Guarantee Program

TSLF Term Securities Lending Facility 


\section{Sumário}

Introdução

Primeira Parte: A recente crise financeira internacional global, os objetivos e o papel

desempenhado pelas autoridades monetária e fiscal dos Estados Unidos

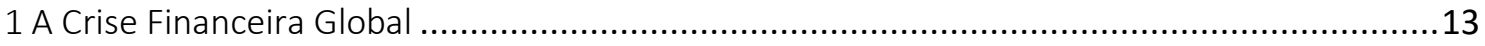

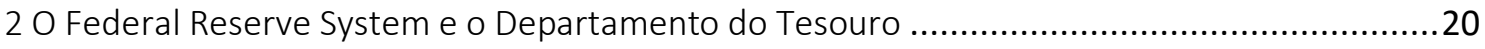

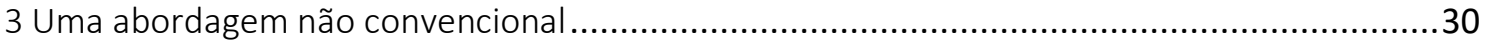

Segunda Parte: A convergência entre as políticas adotadas pelo FED e o Tesouro entre 2008 e 2011.

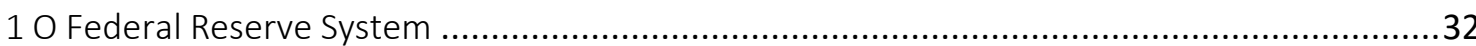

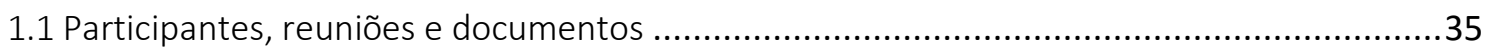

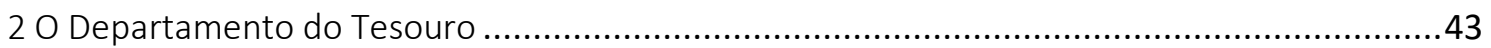

2.1 Documentos emitidos pelo Departamento do Tesouro........................................................45

3 A interação entre as políticas monetária e fiscal .................................................................. 48

3.1 Empréstimos de curto-prazo a instituições financeiras ......................................................49

3.2 Provisão de liquidez, garantia e capital a mercados específicos ..........................................53

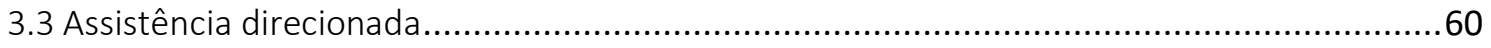

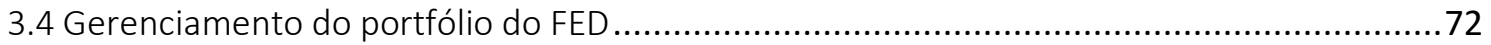

4 Convergência das políticas anti-crise.............................................................................. 79

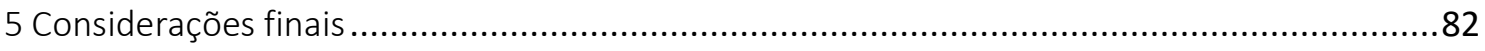

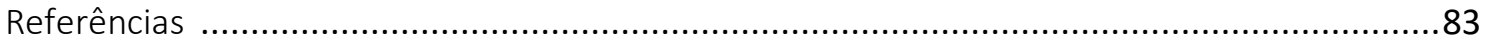

APÊNDICE A - Principais ações e decisões do Federal Reserve System (FED) e do Departamento

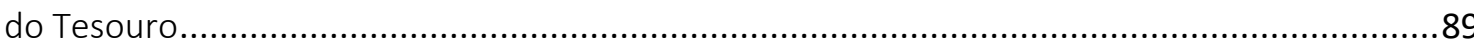

APÊNDICE B - Principais fatos e eventos entre o segundo semestre de 2008 e primeiro semestre de 2011. 101 


\section{Introdução}

O Federal Reserve System (FED) e o Departamento do Tesouro dos Estados Unidos (Tesouro) desempenham importante papel na manutenção da estabilidade macroeconômica norte-americana, sendo responsáveis pela política monetária e fiscal doméstica, respectivamente. Contudo, a relação entre os dois organismos nem sempre é simples, principalmente em períodos de recessão e de instabilidade, quando as pressões políticas são mais intensas.

Um desses momentos surgiu a partir de setembro de 2008, quando a escassez de crédito no mercado interbancário e a espiral de queda no preço de ativos, dos quais dependiam instituições bancárias e não-bancárias, levaram a crise se alastrar pelos mercados extremamente interconectados e desregulados ao redor do globo.

Situação só comparável à Grande Crise de 1929, a recente turbulência financeira chocou autoridades e especialistas que até então reafirmavam a resiliência da avançada economia norte-americana, a capacidade de os mercados se auto-regularem e de bancos e agências avaliarem apropriadamente os riscos de suas operações.

Assim, na primeira parte, este trabalho procura explicitar de forma sucinta como surgiram as bolhas nos mercados imobiliário e de crédito, além de apresentar os objetivos e o papel das instituições que lideraram as respostas do governo a essas ameaças, o FED e o Tesouro.

$\mathrm{Na}$ segunda parte, procurou-se detalhar como essas entidades trabalham, suas estruturas e seu funcionamento interno, servindo como base para expor as ações elaboradas e implementadas no período entre 2008-2011. A pesquisa usou como fontes atas de reuniões do comitê de política monetária, relatórios de desempenho anuais do FED, do Tesouro, da saúde financeira do governo dos Estados Unidos, bem como, discursos e depoimentos das suas principais autoridades.

Reunindo essas medidas e programas em quatro grandes grupos, buscou-se esclarecer quais foram as estratégias adotadas pelos formuladores de política monetária e fiscal, e de como elas interagiram, contando com uma breve análise do ativismo dessas duas entidades. 
Por fim, nas considerações finais, o estudo pretende demonstrar que as políticas desenvolvidas pelo FED e o Tesouro convergiram na maior parte do tempo, a despeito dos custos fiscais e políticos envolvidos.

Primeira Parte: A recente crise financeira internacional global, os objetivos e o papel desempenhado pelas autoridades monetária e fiscal dos Estados Unidos.

A restrição de liquidez e crédito originada pela crise desde 2008 e seus efeitos a economia real levaram o FED e o Tesouro a atuar. As políticas emergenciais assumiram uma importância crescente a partir da aprovação, pelo Congresso, de pacotes fiscais de bilhões de dólares.

Nesse processo, a fé na eficiência dos mercados perdeu espaço para o ativismo governamental. A fragilidade dos mercados colocou em dúvida a capacidade do sistema monetário e financeiro internacional prover a estrutura e regulação adequadas para evitar o risco sistêmico.

Desse modo, a primeira parte desse trabalho procura contemplar algumas abordagens da literatura sobre crises e recessões, o movimento de desregulamentação financeira da década de 90 e sua relação com a maior instabilidade global entre 2008-2011.

Em seguida, investiga como atuam e interagem as instituições responsáveis pela política econômica do governo dos Estados Unidos. Compreender essa relação passa pela consideração de questões importantes como, a credibilidade e independência do banco central, o equilíbrio das finanças públicas e a centralidade do papel desempenhado pelo dólar.

\section{A Crise Financeira Global}

Uma crise financeira pode ser definida como uma interrupção significativa das atividades dos mercados financeiros, das instituições, com efeitos nas atividades econômicas, 
tipicamente precedida por uma expansão rápida da dívida pública e privada, ou aumento de disponibilidade de dinheiro (THOMAS, 2011).

Uns avaliam as turbulências financeiras como eventos extraordinários ou circunstâncias únicas, enquanto alguns autores as consideram parte do sistema capitalista moderno, que segue um curso claro e previsível, com recorrentes episódios de crise na história econômica mundial. Outros entendem que essa é uma consequência inevitável da atividade financeira que é lidar com o risco, o resultado da incapacidade do mercado em mensurar adequadamente esses riscos, ou mesmo, das práticas imprudentes e instituições fracas de determinados países (GILPIN, 2001; WYPLOSZ, 1999, HAUSMANN; VELASCO, 2004).

Entre todas essas abordagens, certas características são comuns, o forte avanço no preço de ativos e posterior declínio, decorrente de um choque, uma incerteza grave ou da aversão ao risco. Com isso, a disponibilidade de crédito é radicalmente reduzida, comprometendo o desempenho da atividade econômica.

Em geral, as crises bancárias e monetárias da década de 1990, caracterizaram-se pela perda de confiança na capacidade de Estados honrarem seus compromissos, acarretando na dificuldade em renovar empréstimos, na perda de reservas internacionais e por fim, na desvalorização das moedas.

A recente crise financeira global, todavia, seguiu um curso distinto. Precedida por um período de inflação baixa, crescimento alto e recessões moderadas, conhecido como $\mathrm{A}$ Grande Moderação (ROUBINI; MIHN, 2010). A crença em uma nova era de estabilidade levou muitos agentes privados a assumirem maiores riscos, movidos também pelo sucesso da política macroeconômica do FED e pela convicção de que o banco central garantiria um nível mínimo nos preços dos ativos. ${ }^{1}$

Isso significou uma época de crescimento prolongado nos Estados Unidos, brevemente interrompida em 2001 pelo estouro da bolha das empresas de tecnologia e internet. 0 boom econômico foi então sustentado por novos estímulos ao consumo, com a

\footnotetext{
${ }^{1}$ A ideia também ficou conhecida pela expressão "Greenspan put" (opção de venda Greenspan), em referência a Alan Greenspan, o presidente do banco central norte-americano entre 1987-2006 (EICHENGREEN, 2011).
} 
disponibilidade contínua de crédito e, em seguida, por uma política monetária frouxa. 0 efeito riqueza era ainda maximizado pela reciclagem dos excedentes de exportação asiáticos por meio da compra de títulos nacionais, "[...] barateando os custos de endividamento ao expandir a liquidez dentro do sistema financeiro". ${ }^{2}$

Os Estados Unidos tornaram-se tão dependentes desse fluxo externo de recursos e os negócios de suas instituições financeiras estavam tão integrados aos de outras entidades estrangeiras, que o ex-presidente do banco central “[...], Ben Bernanke, não tinha o luxo de aguardar até que o sol nascesse em Washington para realizar decisões e fazer pronunciamentos". ${ }^{3}$

As transformações no sistema bancário norte-americano foram imensas. De acordo com Gowan (2009), a estrutura e a dinâmica desse novo sistema podem ser divididas em seis categorias inter-relacionadas, apresentadas a seguir.

A primeira mudança verificou-se nos próprios bancos comerciais e de investimentos, que passaram a realizar (i) aplicações diretas em títulos financeiros e outros ativos, além de realizar empréstimos a fundos e demais instituições financeiras. ${ }^{4}$

Essas operações eram coordenadas por alguns poucos agentes econômicos, cujo alto grau de alavancagem permitia a realização de uma (ii) "arbitragem especulativa", caracterizada pelo desenvolvimento de bolhas nos preços dos ativos, proporcionando grandes lucros até estourarem a bolha, ao se retirarem do mercado. ${ }^{5}$

A necessidade de (iii) expandir o balanço patrimonial e de maximizar a alavancagem levou, por sua vez, à ascensão de um (iv) setor bancário paralelo, composto por fundos de hedge, grupos de private equity, veículos de investimento especial ou special purpose

\footnotetext{
2 (GOWAN, 2009, p.66).

3 (WESSEL, 2010, p.2, tradução nossa)

${ }^{4}$ Gowan (2009, p.52) esclarece que a volatilidade dos mercados de câmbio e a remoção de controles de capital e abertura de outros sistemas financeiros a operadores norte-americanos propiciaram a oportunidade de expansão das atividades de Wall Street, através de proprietary trading e de corretagem prime, investimentos especulativos e de curto prazo.

${ }^{5}$ A alavancagem representa a proporção entre o capital de terceiros e o capital próprio. São dois os motivos para os bancos operarem sempre no limite máximo de alavancagem: a pressão dos acionistas, para gerar maiores lucros, e necessidade de escala operacional financeira, para estabelecer preços para mover os mercados segundo seus interesses (GOWAN, 2009, p.54).
} 
vehicles (SPV), conduits e outras estruturas financeiras sem qualquer capital próprio ou controle regulatório.

A importância dos recém-criados mercados de balcão para a negociação de derivativos, como obrigações de dívida colateralizada (CDOs, em inglês) e credit default swaps (CDS), também é notada por Braga (2009, p.97).

Por um lado, essas inovações financeiras não exigiam dos bancos o compromisso de parcelas de capital como garantia, mas por outro, "[...] vinham de centenas de milhares de fontes, cuja solvência e capacidade de fluxo de caixa não eram consideradas [...]", seus preços não poderiam ser determinados por um mercado secundário e seu risco de contraparte não poderia ser minimizado, como em um mercado organizado. ${ }^{6}$

De todo modo, Gowan (2009) ressalta a construção de um Novo Sistema de Wall Street, arquitetado por grandes bancos norte-americanos cujas operações com produtos securitizados foram concentradas em Londres, onde poderiam ser autorregulados. Legitimado por reguladores crentes no livre funcionamento dos mercados, o novo sistema promoveu alterações no ambiente regulatório em geral, inspiradas nos

[...] Acordos de Basiléia, compostos por índices de capital em relação aos ativos, segundo tipos de riscos, por agências de classificação de risco, por modelos de autogestão armados pelos grandes players bancários, pela supervisão à distância de mercado na prática da transparência das informações, etc. (BRAGA, 2009, p.96). ${ }^{7}$

Com a expansão desse novo sistema, as atividades dessas instituições passaram a depender do financiamento proveniente dos (v) mercados monetários, interbancário e de papéis comerciais; usados tradicionalmente para assegurar o fechamento das posições diárias de bancos e facilitar as operações de curto prazo de grandes corporações; respectivamente.

Na outra ponta, (vi) fundos de pensão e fundos mútuos com uma quantidade enorme de recursos disponíveis em todo o globo tornaram-se os principais investidores de títulos

\footnotetext{
${ }^{6}$ (GOWAN, 2009, p. 56).

${ }^{7}$ Nos Estados Unidos, o setor conseguiu que fosse aprovado o relaxamento da "regra de capital líquido" pela Securities and Exchange Commission (SEC) em 2004, permitindo que os bancos pudessem determinar sua própria alavancagem tendo como base seus próprios modelos de risco. Além disso, a emenda $401 \mathrm{~K}$ de 1980 já havia reformado a legislação tributária, concedendo isenção de impostos a empregados e empregadores que investissem em planos de pensão (GOWAN, 2009, p.57\&58).
} 
lastreados em hipoteca subprime, considerados super seguros (AAA) por agências de classificação de risco.

Assim, em 2007, quando atingiu o mercado de imóveis residenciais, a crise logo se espalhou para os fundos de investimento especializados em securitização de títulos, e mais tarde, transformou-se em uma grande liquidação de títulos mobiliários (EICHENGREEN, 2011).

Ao perceberem a grande instabilidade do mercado imobiliário norte-americano, muitos operadores dentro do sistema financeiro passaram a reavaliar as dívidas acumuladas, descobrindo que grande parte dela havia sido securitizada.

Distribuídos pelos bancos para disseminar o risco, esses produtos deixaram de ter preço de mercado determinado ou mecanismos de precificação. Financiadores interromperam os empréstimos de curto prazo necessários para manter o mercado de CDOs ativo, e os bancos, ao tentarem repassá-los, não encontraram nenhum mercado para essas inovações financeiras. Já as companhias de seguro viram seu negócio entrar em colapso - pois eram responsáveis pelas emissões de CDS, seguros para CDOs.

A incerteza se alastrou pelos mercados monetários. Ninguém sabia ao certo quais bancos mantinham esses produtos em seu balanço patrimonial, se essas instituições estavam ilíquidas ou insolventes. A criativa contabilidade financeira que tinha se difundido anos antes em Wall Street fez com que investidores reagissem de forma a procurar ativos mais confiáveis, como os títulos públicos norte-americanos. Na visão de Braga (2009, p.94);

A surpresa não foi a sua ocorrência, mas a extensão com que ela [a crise] penetrou os sistemas financeiros nacionais e os mais distintos atores, e a forma insinuante e insidiosa de inovações financeiras. Viu-se a omissão das autoridades monetárias, supervisoras, fiscalizadores, etc.

Na visão de Cukierman (2012), para explicar a formação da bolha imobiliária e a definição de repostas políticas governamentais deve-se abordar quatro fatores primordiais e a interação entre eles: a ideologia, a política, as instituições e o conhecimento econômico. Primeiro, o autor destaca que a filosofia econômica predominante nos Estados Unidos é que mercados privados devem operar livremente sempre que possível. 
Esse discurso, reforçado pelas próprias instituições financeiras, implicava que o Estado deveria limitar suas ações sobre a economia para permitir a maximização dos lucros, o que se refletia no pouco empenho de congressistas na produção de uma regulação e supervisão séria, como também, na natureza descentralizada das entidades regulatórias do país. ${ }^{8}$

Mais interessante, na tentativa de garantir moradia a pessoas de baixa renda, parlamentares incentivaram agências governamentais ou government sponsored enterprises (GSEs) a ampliar financiamentos a taxas menores que as cobradas pelo mercado. Dessa forma, a qualidade do risco de crédito da Fannie Mae e Freddie Mac foi se deteriorando.

Último ponto de destaque, mas não menos relevante, foi a política monetária fundamentada na redução das taxas de juros de forma rápida para evitar uma recessão, seguida por um aumento para combater a inflação em decorrência da expansão já esperada. Dessa forma, criou-se um viés para a prática de taxas de juros baixas, facilitando exatamente a formação de bolhas (CUKIERMAN, 2012).

Em síntese, Thomas (2011) coloca que os seis primeiros anos do século XXI foram marcados pelo desenvolvimento de duas bolhas, uma de crédito e outra imobiliária. De um lado atuava o "espírito animal" e a noção de que os preços das casas nunca poderiam cair, e de outro, entidades financeiras e bancos de Wall Street convencidos de sua capacidade em medir acertadamente os riscos e em tomar as medidas necessárias para praticamente eliminá-los.

Ademais, o padrão de concessão de crédito se degradou continuamente, enquanto que o arcabouço regulatório pouco conseguiu avançar no sentido de abarcar os rápidos desenvolvimentos financeiros.

Esse panorama caótico exigiu ações emergenciais, e as respostas a crise financeira global foram certamente influenciadas pela experiência da Grande Depressão, tendo as autoridades colocado em prática muitas das lições de Keynes para estimular a demanda

\footnotetext{
${ }^{8}$ Apesar de ser uma tentativa dos reguladores prevenir as crises, na maioria das economias ocidentais qualquer atitude nesse sentido é bastante criticada por políticos e pelo público em geral. Cukierman (2012, p. 579) lembra que crises são muito difíceis de prever e que se criou uma estrutura que não permite a mobilização de apoio para medidas preemptivas e favorece a leniência excessiva das autoridades.
} 
agregada. Em todo o mundo, as taxas de juros despencaram e os bancos centrais disponibilizaram volumes astronômicos para financiar importantes setores da economia. As taxas de juros praticadas pelo FED passaram de 5,25\% no verão de 2007 para o chamado zero lower bound no final de 2008. Wessel lembra que nos Estados Unidos, o banco central foi o primeiro a responder, como "[...] uma quarta entidade governamental, com poder quase igual ao do Executivo, Legislativo e Judiciário, [...]". ${ }^{9}$

Com a nacionalização das GSEs, a falência do Lehman Brothers e o resgate à AIG, o Congresso teve apenas duas semanas para avaliar informações, debater e analisar o projeto do primeiro pacote fiscal (CUKIERMAN, 2012).

Sob forte pressão, os parlamentares estavam relutantes em comprometer um grande montante de dinheiro público a menos que tivessem garantias que o contribuinte seria reembolsado. O Troubled Asset Relief Program (TARP), medida emergencial que previa o uso de até USD 700 bilhões para a compra de ativos tóxicos, foi aprovado apenas quando a administração Bush revisou a proposta, consentindo com a aquisição de posições acionárias em bancos.

Às vésperas das eleições, os congressistas também incluíram mecanismos mais rigorosos de supervisão, ampliaram os objetivos do programa e a procuraram limitar a remuneração dos principais executivos das instituições financeiras favorecidas pela assistência estatal. Efetivamente, o Congresso tinha pouco controle sobre o TARP, sendo a maior parte da responsabilidade delegada ao Tesouro e demais agências do Executivo. A administração Obama, ao contrário da anterior, desenvolveu um segundo pacote fiscal que privilegiou o corte em impostos federais, a expansão de benefícios para desempregados e outros gastos na área social.

De todo modo, ambos os governos empreenderam enormes esforços para evitar uma estatização geral do sistema bancário e minimizar a visibilidade da nacionalização parcial realizada pelo primeiro programa (CUKIERMAN, 2012).

\footnotetext{
${ }^{9}$ (WESSEL, 2010, p. 3, tradução nossa).
} 
Ainda assim, houve intensa discussão sobre a necessidade de uma maior regulação dos mercados financeiros, na esfera doméstica e internacional, muito diferente do que fora visto dez anos antes no Sudeste Asiático.

Nesse sentido, a legitimidade das políticas neoliberais e das lideranças financeiras norteamericana e britânica foram profundamente abaladas. A origem do pânico se deu nos mesmos mercados que serviam de modelo para os padrões internacionais de regulamentação, e cujas autoridades empreenderam massivos resgates a entidades financeiras privadas com o dinheiro público (HELLEINER, 2010).

Em uma das maiores intervenções estatais da história do capitalismo, o FED, o Tesouro e o Congresso superaram divergências e trabalharam bem próximos, estabelecendo uma coordenação razoável. O banco central colocou seus interesses institucionais em segundo plano, ao defender o uso de todas as ferramentas à sua disposição.

Essa cooperação pode ser percebida através das políticas implementadas e do comportamento dessas entidades (BORDO, 2010), consistentes com um foco na "preservação da normalidade e funcionalidade do sistema financeiro como a primeira prioridade da política pública dos Estados Unidos". ${ }^{10}$

Por isso, é fundamental compreender a estrutura e modo de funcionamento das instituições responsáveis pelas políticas monetária e fiscal do governo dos Estados Unidos, bem como discutir as grandes questões que permeiam sua inter-relação, em particular após a eclosão da crise de 2008.

\section{Federal Reserve System e o Departamento do Tesouro}

Apesar de o FED estar entre as mais poderosas instituições governamentais, ela é pouco estudada por estudiosos da ciência política de forma sistemática. Contudo, a entidade gera um grande impacto sobre outros órgãos estatais ao definir, elaborar e implementar

\footnotetext{
${ }^{10}$ (CUKIERMAN, 2012, p. 584, tradução nossa).
} 
políticas públicas em um campo permeado por conflito de interesses. (WOOLEY, 1984, p.1).

Encarregado de elaborar e conduzir a política monetária, o banco central norteamericano possui o duplo mandato de promover a estabilidade macroeconômica e financeira do país. Seus objetivos incluem a manutenção da inflação em um patamar baixo e estável e de um crescimento sustentável do produto interno e do emprego.

Já para assegurar o funcionamento adequado do sistema financeiro nacional, a instituição atua como supervisor e emprestador de última instância, para evitar crises ou promover a liquidez de curto prazo em períodos de instabilidade.

De todo modo, os efeitos produzidos pela política monetária sobre a performance da economia do país são bastante poderosos. A adoção de medidas expansionistas ou contracionistas baseadas em critérios técnicos seria suficiente para manter o controle da inflação e do crescimento. Isso, claro, se não fosse a dificuldade em estabelecer a dose correta de qual remédio a ser aplicado, parafraseando Wooley (1984).

A decisão de acomodar ou de combater a inflação tanto afeta a economia e a sociedade, como também tem implicações sobre a popularidade e o sucesso eleitoral do governo. Em última instância, as escolhas de política monetária seriam fenômenos políticos.

O discurso característico do seu principal órgão deliberativo, Federal Open Market Committee (FOMC) encontra-se no campo técnico da análise econômica padronizada governada pela linguagem precisa, consistência lógica, rigor matemático, validação empírica e teoria inclusiva parcimoniosa. Já o presidente da República e o Congresso desenvolvem um discurso político comum, direcionado para a sua base eleitoral e, muitas vezes, preocupado com a designação de um culpado (WOOLEY, 1984, p.9).

Essa divisão é importante pois determinaria a habilidade para influenciar escolhas políticas e, por conseguinte, o curso dessas próprias políticas. Nesse caso, aspectos técnicos acabam por excluir e limitar o número de participantes; e, como em qualquer outra agência do governo, o FED permite acesso a determinados interesses especializados e bloqueia outros. 
No entanto, "[...] o público não pode aplicar sanções ao FED. Ele culpa seus representantes políticos [...]" ao invés disso (MELTZER, 2010, p.305). Portanto, não é raro que a autoridade monetária sofra alguma pressão do Congresso ou do Tesouro, parte do Executivo.

O Departamento do Tesouro foi uma das primeiras agências a serem criadas pelo governo dos Estados Unidos, com a responsabilidade de gerenciar as finanças e os recursos, incluindo a elaboração do orçamento e a organização da dívida pública.

Sua missão inclui prezar pela manutenção de uma economia forte e pelo nível de emprego, e ainda, por fortalecer a segurança nacional, combatendo ameaças e protegendo a integridade do sistema financeiro nacional.

Cabe ressaltar que as questões fiscais seguem as estratégias e prioridades delineadas pela própria administração, sendo o principal instrumento de política econômica do setor público (MENDONÇA, 2011).

Em geral, congressistas tendem a incentivar maiores taxas de emprego e de crescimento para obter ganhos em época de eleição, ignorando consequências futuras como efeitos decorrentes de maiores taxas de inflação e de juros. Ainda, partidos procuram retardar decisões importantes, em meio a guerras de interesses e posições conflitantes em relação à forma de solucionar problemas orçamentários, por exemplo.

Os custos de promover ações econômicas restritivas são grandes. Envolvem necessariamente cortes nos gastos governamentais e/ou aumento de impostos, medidas que são preteridas em favor de um maior endividamento público.

No caso norte-americano, o financiamento da dívida interna do Tesouro também está atrelado a um déficit externo, dada a reduzida taxa de poupança interna e a crescente despesa com programas sociais. Aliada a esse fato, a absorção doméstica tem sido maior do que o produto da economia por anos, acarretando igualmente em um persistente desequilíbrio em transações correntes.

Para Bernanke (2005), uma combinação de forças diversas criou um aumento significativo na capacidade global de poupança, ajudando a explicar a evolução do déficit 
em transações correntes norte-americano e o baixo nível relativo das taxas de juros de longo-prazo no mundo.

Essas forças englobam os fluxos de capitais internacionais, os recursos poupados para a aposentadoria em países desenvolvidos e, a política de acumulação de países emergentes. A série de crises da década de 90 e o aumento no valor do petróleo levaram economias em desenvolvimento a canalizar recursos domésticos para a compra de títulos do Tesouro norte-americano. De fato, a mudança no padrão de conta corrente ajudou a colocar os Estados Unidos, a opção mais atrativa para investidores, na condição de maior devedor do mundo.

Essa perspectiva é contestada por Eichengreen (2011), que argumenta que a crise asiática levou à implementação de reformas recessivas, fazendo efetivamente com que a taxa de poupança nessas economias diminuísse. Mas, ao buscarem alternativas à carência de investimentos internos, os fluxos financeiros da Ásia encontraram nos bônus do governo dos Estados Unidos e nos títulos das GSEs um destino "natural".

Segundo De Cecco (2012), o fenômeno formulado por Bernanke teve suas raízes na frouxa política monetária do FED, cujo objetivo era impulsionar bancos a conceder hipotecas e empréstimos a consumidores. O "global savings glut", dessa forma, pretendia justificar a ausência de poupança interna do país e compartilhar o ônus pelo desequilíbrio global com os poupadores compulsivos, principalmente de origem chinesa. ${ }^{11}$

Nesse sentido, para garantir que o governo assuma os custos de uma contração fiscal e reduzir as distorções políticas é compreensível que (i) sejam instituídas regras para equilibrar o orçamento e, que (ii) as políticas fiscal e monetária sejam autônomas. A determinação de um teto para a dívida bruta federal foi um dos mecanismos criados para limitar o crescimento indiscriminado da dívida, e a constituição de uma autoridade monetária foi a resposta à segunda demanda.

\footnotetext{
${ }^{11}$ Nessa mesma linha, Cukierman (2012, p.579) esclarece que a ideologia do livre mercado também contribuiu para a "negligência benigna" dos políticos norte-americanos em relação ao alto e persistente desequilíbrio da conta corrente do país com a China. Ao produzir uma simbiose entre os dois países, esses investidores puderam prosseguir com a sua política de crescimento baseada em exportações e de formação de uma grande poupança interna.
} 
Dois bancos centrais "temporários" foram criados nos Estados Unidos durante o século XIX, entretanto, nessas duas tentativas, os esforços foram anulados devido a batalhas políticas em torno da distribuição de poder entre as diversas regiões e classes (DURAN, 2012).

Em razão das frequentes crises financeiras (1893-94, 1895-97, 1899-1900, 1902-04, 1907-08 e 1910-12), o Congresso passou a discutir seriamente o tema. A nação não poderia depender somente de um indivíduo para desempenhar o papel de emprestador de última instância, a exemplo do que J. Pierpont Morgan fez ao reunir colegas banqueiros e oficiais do Tesouro para mitigar o pânico de 1907 (THOMAS, 2011).

A Comissão Monetária Nacional, instituída conforme disposto pelo Aldrich-Vreeland Act, foi responsável pela apresentação de relatório final que recomendava a criação de um Federal Reserve System (FED).

O plano inicial colocava a necessidade de uma associação nacional que cuidasse de parte das reservas bancárias de seus membros, determinasse as taxas de redesconto, comprasse e vendesse instrumentos financeiros no mercado aberto e cunhasse moeda. Esse projeto foi resgatado anos mais tarde e estruturado de forma a permitir um maior espaço para a influência política.

Assim que o Legislativo conseguiu resolver divergências em torno do funcionamento do organismo conforme disposto nos planos Aldrich e Glass, foi possível alcançar um grande consenso que culminou com o Federal Reserve Act de 1913 (WOLLEY,1984, p.39).

A responsabilidade fundamental dessa instituição seria a suavização dos efeitos das demandas cíclicas e sazonais por liquidez, fornecendo para toda a nação "reservas mais elásticas via seus novos mecanismos" (CALOMIRIS, 2010, p. 12, tradução nossa). Ou seja, garantiria a provisão de um bem público para toda a economia, a estabilidade da moeda.

Sem status constitucional e vulnerável à interferência do Congresso, o FED combinou uma estrutura descentralizada, dependendo sua existência da influência exercida por interesses opostos. Para Calomiris (2010, p. 13, tradução nossa), "o FED era uma barganha estável", cujo arcabouço conduziu a uma maior independência do órgão, reduzindo as interferências tanto de Wall Street como do governo central. 
Mas essa estrutura descentralizada não conseguiu atender a demanda por maior flexibilidade na expansão da base monetária em seu primeiro grande teste, a Grande Depressão de 1929 (DURAN, 2012). O ex-presidente do FED entre 2006-2014, Ben Bernanke, responsabilizou a própria entidade pelo episódio em razão da interação entre instituições falhas, decisões políticas míopes e condições políticas e econômicas desfavoráveis (WESSEL, 2010).

Até a década de 1930 algumas reformas foram realizadas a fim de consolidar os poderes do comitê responsável pela tomada das decisões em política monetária. O mandato de seus diretores foi estendido, o orçamento da instituição passou a ser independente, e o Secretário do Tesouro e o Comptroller of the Currency foram removidos da instituição; que passou a prestar contas diretamente ao Congresso, através de um relatório anual. ${ }^{12}$ De fato, essas mudanças não foram suficientes para evitar que o FED se comportasse de forma passiva ou mesmo subserviente à autoridade fiscal durante os anos seguintes (CALOMIRIS, 2010; BORDO, 2010). Existia um compromisso tácito para a manutenção de juros baixos com o intuito de não comprometer a capacidade de refinanciamento do Tesouro. Durante a II Guerra Mundial, novamente, a instituição precisou seguir os requisitos de financiamento de guerra (WOOLEY, 1984).

Findo o conflito internacional, o banco central obteve autonomia efetiva com o massivo crescimento de seu balanço. Ao longo do padrão ouro, o FED adquiriu

[...] independência operacional sobre o seu balanço e independência financeira para se financiar com a renda líquida dos juros, de forma a libertar o seu poder de criação de dinheiro da política orçamentária, potencialmente inflacionária (GOODFRIEND, 2012, p.6, tradução nossa).

O U.S. Treasury-FED Accord de 1951 tratou de assegurar o fim da pressão governamental, e o Federal Reserve Reform Act of 1977 conferiu ao banco central propósitos explícitos, estabilidade de preços e o pleno emprego (GOODFRIEND, 2010, p.2; DURAN, 2012, p.170). Essas medidas atribuíram grande credibilidade a entidade. Ao determinar as taxas de juros pagas aos investidores como remuneração pelos investimentos em títulos

\footnotetext{
${ }^{12}$ Essas reformas incluíram o Banking Act de 1933 (Glass-Steagall Act) e o Banking Act de 1935 (DURAN, 2012, p.170).
} 
públicos nacionais, o FED poderia finalmente perseguir uma meta inflacionária de longo prazo. ${ }^{13}$

Apesar disso, a instituição evitou aumentar as taxas de juros e contrair a economia até a década de 1980, quando Volcker assumiu a presidência. Finalmente, o FED exercia a sua autoridade e utilizava os instrumentos à sua disposição para reduzir o perigo de inflação. (CALOMIRIS, 2010). Isso se deveu, de um lado, ao fato de que a opinião pública considerava a inflação como o mais importante problema econômico e, de outro, o suporte do Congresso (MELTZER, 2010).

No período da Grande Moderação, entre 1984 e 2006, o banco central também demonstrou grande compromisso com a manutenção de uma inflação baixa (BORDO, 2010). Mas, enquanto a maioria dos bancos centrais passou a definir metas de inflação para garantir sua credibilidade, a entidade não adotou esse tipo de política, o que não impediu que ela fosse bem-sucedida (BLANCHARD, 2011).

Dessa forma, "[...] o FED aprendeu que a política monetária independente efetiva precisa da disciplina de um compromisso crível com a inflação baixa" (GOODFRIEND, 2010, p.2). Essa independência é reconhecida, atualmente, como o elemento central para a fundação institucional de uma política monetária eficaz. O banco central deve manter distanciamento em relação aos assuntos políticos do momento, estando preparado para elevar as taxas de juros de forma preemptiva ou até agressiva, permitir a variação dessa taxa conforme os ciclos econômicos ou ancorar a própria inflação ou as expectativas de inflação.

Para Wooley (1984, p. 43, tradução nossa), “o FED tem considerável autoridade e poucas orientações políticas significativas". A regra de Bagehot, por exemplo, nunca foi seguida pelo banco central norte-americano. Ainda, o Congresso retirou a maior parte das limitações impostas à política de crédito emergencial do FED. ${ }^{14}$

\footnotetext{
${ }^{13} \mathrm{Na}$ década de 1970, também foram promulgados o Full Employment Act e o Federal Banking Agency Audit Act, determinando provisões de accountability mais claras ao FED (DURAN, 2012, p.171).

${ }^{14}$ Para estabilizar os mercados financeiros durante um pânico, Walter Bagehot defendia que o banco central deveria empestar livremente, exigindo, em troca, altas taxas de retorno e boas garantias (GOODFRIEND, 2012, p.1).
} 
Em 1932, a seção 13(3) do Federal Reserve Act foi alterada, retirando a proibição de emprestar a outras entidades que não instituições depositárias. Na prática, a exigência de garantias tornou a medida restritiva, apesar da nova revisão realizada em 1935.

Com a aprovação do Federal Deposit Insurance Corporation Improvement Act (FDICIA), de 1991, o Congresso garantiu autoridade ilimitada ao FED para emprestar em circunstâncias consideradas "unusual and exigent". Produziu-se, então, uma ambiguidade em relação aos limites das responsabilidades do banco central, os poderes fiscais relacionados à política monetária e à política de crédito.

Essa última envolve emprestar a instituições privadas, ou adquirir títulos outros que não do Tesouro, por meio de recém criadas reservas bancárias ou a partir proventos com a venda de ouro e títulos do governo. Na sua história, o FED praticou dois tipos de política de crédito independente.

O "borrowed reserve targeting" surgiu em 1923 com a proibição administrativa de conceder empréstimos continuamente através da janela de redesconto. Assim, a taxa de redesconto passou a servir de piso e não mais de teto para as demais taxas do mercado monetário de curto-prazo. E, ao determinar a quantidade de reservas bancárias, o FED passou a influenciar ambas as taxas e os empréstimos. ${ }^{15}$

Essa estratégia foi aplicada entre os anos 1920 e 1980 para ocultar as ações de política de taxa de juros do banco central, mas sob um custo muito alto, que o banco central repassava às autoridades fiscais na forma de receitas menores.

Já a segunda política, de assistência de crédito emergencial, foi empregada com o advento da recente crise financeira, e marcou "uma mudança de comportamento institucional do FED" (DURAN, 2012, p.174). Foram desenhados novos mecanismos de controle monetário, com a expansão radical dos empréstimos do banco central, em termos de escala, prazo e garantias aceitas.

Pela primeira vez na história, a entidade passou a trabalhar com ativos tóxicos, introduzindo uma grande quantidade de instrumentos ilíquidos e de longo-prazo em seu

\footnotetext{
15 Esse mecanismo permitiu ao FED criar a ilusão de que as taxas do mercado monetário eram determinadas por forças do mercado (GOODFRIEND, 2012, p.12).
} 
balanço. Ao alocar crédito para ajudar o setor imobiliário e ao mesclar a política de crédito e a política monetária, o FED anula a sua independência, prejudicando também, a sua capacidade em reduzir o volume de reservas excedentes (MELTZER, 2010, p.305).

Ampliar o financiamento a empresas financeiras não bancárias está relacionado ao fato de que a alocação de crédito é uma prerrogativa política, com potencial para degradar a independência financeira da autoridade monetária (GOODFRIEND, 2010, p.13).

A ausência de regras, por conseguinte, encorajaria empresas a pressionarem parlamentares que, por sua vez, tentariam influenciar as ações do banco central. Um exemplo emblemático foi o ressurgimento do tema da nomeação de presidentes dos FRBs no Congresso. Escolhidos diretamente por participantes do mercado, esses presidentes são menos influenciados por pressões políticas. ${ }^{16}$

Outro problema indicado por Meltzer (2010) é que, ao invés de seguir o seu duplo mandato, o FED lida com apenas um problema de cada vez. A instituição negligencia as implicações de longo prazo de suas ações políticas, destacando que a história não mostra exemplos de países que conseguiram fugir da inflação ao enfrentar um alto crescimento de moeda, grandes e recorrentes déficits orçamentários e a depreciação da moeda.

Além disso, "[o] governo não responde como [eles] pretendem financiar seus déficits ou reduzi-los [...]" (MELTZER, 2010, p.303\&304). E em períodos de instabilidade econômica e financeira, o endividamento externo pode representar uma limitação à ação do governo na economia (CECCHETTI, 2009).

Contudo, ainda em setembro de 2008, o presidente dos Estados Unidos afirmava que "[...] o governo [era] a única instituição com paciência e recursos para comprar esses ativos [tóxicos] pelo preço baixo atual e mantê-los até que o mercado volte ao normal" (BUSH, 2008).

É amplamente aceito que os déficits do governo aumentem durante um período recessivo, desde que sejam compensados por superávits em momentos de expansão econômica, segundo o princípio do relaxamento de impostos. Os políticos, em geral, não

\footnotetext{
${ }^{16} \mathrm{~A}$ possibilidade de alterar esse padrão de nomeação suscitou uma forte resposta de acadêmicos e de figuras importantes do setor financeiro, produzindo uma petição com 200 assinaturas em apoio à virtual independência incondicional dos poderes monetários e de crédito do FED (GOODFRIEND, 2012 p. 1).
} 
veem problema em permitir a elevação desses déficits, mas em reduzi-los durante o próximo ciclo de crescimento (ALESINA, 2012).

Por um lado, Helleiner (2010) assinala que a crise demonstrou que o poder econômico está se difundindo entre as regiões do globo, ao expor a dependência financeira dos Estados Unidos em relação aos investimentos chineses e demais países superavitários, cada vez mais preocupados com a situação fiscal do governo e com o futuro do dólar como moeda global.

Ao final, muitos investidores poderiam perder a confiança em um país cada vez mais endividado e até parar de financiar sua economia, o que poderia culminar com "a erosão de um dos pilares do sistema internacional: a supremacia financeira dos Estados Unidos e a hegemonia do dólar" (MENDONÇA, 2011). Por outro lado, à medida que a crise atingia novos picos - com a liquidação de fundos de hedge, a venda do Bear Stearns, a falência do Lehman Brothers, "o dólar se fortalecia em comparação com o euro e com outras moedas" (EICHENGREEN, 2011).

Nesse sentido, o tamanho, a liquidez, a eficácia e a transparência dos mercados norteamericanos continuavam a atrair os investidores, que não encontravam a segurança necessária nos seus mercados domésticos ou alternativas interessantes no mercado internacional.

O expressivo investimento à época evidenciou dois aspectos significativos. Primeiro, uma clara demonstração de fuga para a segurança e da credibilidade de suas instituições. Segundo, contribuiu para levar para níveis mínimos os juros pagos por esses títulos, o que pode ser traduzido em custos cada vez mais baixos para os empréstimos do governo e das famílias norte-americanas.

Contraditoriamente às expectativas de colapso da moeda, o dólar experimentou uma valorização, ainda que a crise financeira global tenha se originado nesse país, em seu sistema financeiro, e exigido medidas expansionistas drásticas de suas autoridades monetária e fiscal. ${ }^{17}$

\footnotetext{
${ }^{17}$ De Cecco (2012, p.46, tradução nossa) ressalta que "A conta corrente dos Estados Unidos melhorou significativamente $[. .$.$] ", apontando o que alguns economistas chamam de efeito de "safe heaven" - que$ beneficia o dólar quando o mundo enfrenta uma turbulência econômica e política séria. Uma outra
} 


\section{Uma abordagem não convencional}

A crise financeira global trouxe novas e interessantes questões ao debate da Economia Política Internacional. Mudanças significativas no sistema bancário e regulatório, o livre fluxo de capitais internacionais e as inovações financeiras impulsionaram grande parte dos episódios de instabilidade verificados, principalmente, na década de 1990.

Contudo, mesmo antes de 2008, alguns indícios já apontavam para a formação de uma gigantesca bolha imobiliária nos Estados Unidos. Com instituições sólidas, mercados extremamente avançados e produtos financeiros cada vez mais sofisticados, poucos pensavam na possibilidade de uma turbulência financeira se originar nesse contexto.

Quando a crise atingiu seu auge e a confiança do investidor esvaneceu, o mercado interbancário, o crédito, o financiamento de empresas e famílias, os preços dos ativos, os investimentos, e a taxa de desemprego foram afetados. A complexidade e a interconectividade dessas operações e atividades também ajudam a explicar como, em pouco tempo, a turbulência financeira contaminou o desempenho e o crescimento da economia, nacional e internacional.

Diferentemente do modelo pós-crise empregado em países emergentes, as respostas do governo norte-americano não seguiram regras claras e pré-estabelecidas. Ao contrário, muitas medidas implementadas para estabilizar os mercados foram inovadoras, testadas conforme os episódios de pânico se acumulavam.

O FED passou a reafirmar seu compromisso em empregar todas as ferramentas a sua disposição para reduzir os riscos negativos para o emprego, o consumo e a produção. Sob a maior ameaça econômica vista em uma geração, o Tesouro obteve autorização do Congresso para despender dinheiro de contribuintes da maneira que julgasse apropriado.

explicação coloca as instituições financeiras dos Estados Unidos lutando pela sua sobrevivência, liquidando seus ativos estrangeiros e repatriando todos os seus investimentos, da mesma maneira que investidores externos tiveram de buscar mais dólares para garantir suas operações no mercado. Além disso, as importações do país diminuíram significativamente. 
A ausência de maiores limitações para a atuação dessas duas entidades, definidas pelo Congresso, levou a desconfiança em relação à independência do banco central, à sustentabilidade da posição fiscal do governo central e à posição internacional do dólar. Nesse sentido, a este trabalho interessa especificamente a inter-relação entre o FED e o Tesouro na mais importante economia do planeta. Esclarecer como foram formuladas, coordenadas e colocadas em prática essas estratégias podem auxiliar na compreensão das políticas desenvolvidas a partir do auge da crise até o impasse sobre a elevação do teto da dívida.

Mais importante, podem exemplificar como a flexibilidade dessas duas entidades gerou pontos de convergência entre as políticas adotadas, sem minar a credibilidade ou a legitimidade dos esforços empregados pelo governo norte-americano diante da crise.

\section{Segunda Parte: A convergência entre as políticas adotadas pelo FED e o Tesouro entre 2008 e 2011.}

As autoridades monetária e fiscal foram protagonistas no desenvolvimento de uma reação do governo norte-americano frente à ameaça de total colapso dos mercados monetário e financeiro internacional.

As duas instituições foram responsáveis por criar e implementar várias medidas sem precedentes na história recente do país, mas a articulação entre o FED e o Tesouro suscitou sérios questionamentos, por vezes, de reagirem de forma exagerada, tímida ou até confusa.

Assim, nessa segunda parte, a análise se concentra nas decisões de política monetária e fiscal entre o auge da crise financeira global, em setembro de 2008, até a resolução o impasse da elevação do teto da dívida, em agosto de 2011.

Antes de avaliar programas, comunicados e depoimentos, contudo, este trabalho expõe como cada uma dessas entidades é constituída, atentando para o modo como elas podem sofrer interferências de políticos, de Wall Street e do público em geral. 
Ao compreender os processos políticos internos, do banco central e do Tesouro, este estudo espera contribuir para iluminar as estratégias defendidas pelo governo norteamericano no sentido de superar a instabilidade financeira, o fraco desempenho econômico e reafirmar a disposição do país em garantir o funcionamento e estabilidade do sistema monetário internacional vigente.

\section{Federal Reserve System}

O Federal Reserve System é uma rede que foi designada pelo Congresso a exercer uma função pública, mas combina elementos públicos e privados em seu funcionamento e organização. Foi configurado como um sistema com um Conselho de Diretores ou Board of Governors (Board) e 12 Federal Reserve Banks (FRBs), ou seja, um banco central regional para cada jurisdição geográfica específica (DURAN, 2012).

Em que pese o amplo debate político e na literatura sobre independência do banco central, o FED é considerado um banco central independente, já que suas decisões não precisam ser ratificadas pelo presidente ou qualquer outro membro do Executivo. ${ }^{18}$

Seu principal órgão decisório, o Comitê de Política Monetária ou Federal Open Market Committee (FOMC), é formado pelos membros do Board e mais cinco presidentes de FRBs. A estrutura desse grupo é determinada por sua própria organização interna e, por tradição, as decisões do Comitê são tomadas por consenso em reuniões formais, realizadas oito vezes por ano em Washington, D.C.

A principal finalidade dessas reuniões é definir a taxa de juros nominal de curto prazo da economia, chamada de federal funds rate (fed funds). Essa taxa afeta as taxas de juros efetivas da economia no curto prazo, longo prazo, o valor de câmbio do dólar e os preços dos ativos, além de servir como importante referência para os mercados financeiros.

\footnotetext{
${ }^{18} \mathrm{~A}$ independência do FED não é consenso. A definição apresentada por Meltzer indica que o banco central é "independente dentro do governo, não independente do governo" (Martin apud MELTZER, 2010, p. 281, tradução nossa), reconhecendo que existe uma pressão política. O Congresso pode mudar as regras sob as quais o FED trabalha, e frequentemente se propõe a fazê-lo.
} 
Paralelamente, qualquer alteração nessas variáveis também interfere nos gastos de empresas e cidadãos.

Tradicionalmente, o FOMC procura controlar essa taxa por meio das seguintes ferramentas: operações no mercado aberto, depósitos compulsórios, saldos contratuais de compensação e a janela de redesconto. As operações no mercado aberto correspondem à compra e venda de títulos públicos, e são conduzidas exclusivamente pelo Open Market Trading Desk (Desk ou Mesa) do Federal Reserve Bank of New York (FRBNY). Os títulos do Tesouro norte-americano representam a maior parte dessas negociações, entre a Mesa de operações e os negociadores primários, por meio de leilões regulares. ${ }^{19}$

Os depósitos compulsórios correspondem a uma porcentagem mínima que instituições depositárias devem manter em dinheiro ou em sua conta junto ao FED, enquanto os saldos contratuais consistem em valores utilizados para realizar a compensação de operações financeiras e auferem juros implícitos - na forma de créditos para o pagamento de serviços cobrados pelo banco central.

A janela de redesconto, por sua vez, é um mecanismo do banco central para oferecer extensão de crédito a instituições depositárias através de programas de empréstimo primário, secundário ou sazonal, de acordo com uma determinada taxa de redesconto. ${ }^{20}$ Todavia, somente o Board possui autoridade para mudar a quantidade de reservas obrigatórias depositadas nos FRBs e aprovar qualquer alteração na taxa de redesconto.

\footnotetext{
${ }^{19}$ As instituições depositárias são de três tipos: bancos nacionais, bancos comerciais membros e não membros do FED. Os bancos nacionais respondem ao Office of the Comptroller of the Currency (OCC) do Tesouro e são obrigatoriamente membros do FED, já os bancos comerciais estão sob a responsabilidade dos Estados. Todas as instituições-membro devem manter junto ao FED reservas bancárias em forma de depósito compulsório, saldos contratuais e reservas excedentes. Já os negociadores primários são aquelas instituições depositárias habilitadas a negociar diretamente com a mesa de operações do FRBNY.

${ }^{20}$ Estabelecido pelo Conselho de Diretores dos FRBs a cada duas semanas, os programas de crédito devem ser garantidos por um título com grau de investimento e estão sujeitos a revisão pelo Board. O FED também possui autoridade para estender esse crédito a outras instituições em casos específicos e emergenciais. O crédito primário está disponível a instituições depositárias por um curto período, overnight, por uma taxa de $1 \%$ acima do feds funds. 0 crédito secundário está disponível a mais instituições por uma taxa de $1,5 \%$ acima do feds funds e o crédito sazonal é desenhado para ajudar instituições com problemas de liquidez. Desde 2003, a taxa de redesconto é definida como aquela acima das taxas de mercado, para que a janela seja usada com pouca frequência como recurso de liquidez.
} 
Todos esses instrumentos influenciam diretamente a taxa de juros e, por conseguinte, a demanda e a oferta de moeda e crédito. Entretanto, o banco central enfrenta certos desafios ao seguir o mandato estabelecido pelo Congresso, a saber: promover o pleno emprego, a estabilidade de preços e uma taxa de juros de longo prazo moderada. As tensões entre os seus objetivos de curto prazo e os problemas relacionados à disponibilidade de informação são o principal destaque.

Em primeiro lugar, ao formular a política monetária, os integrantes do FOMC precisam decidir sobre qual aspecto focar no caso de pressões sobre os preços ou sobre o emprego e o crescimento econômico. Por exemplo, um aumento na taxa de juros poderá produzir o efeito desejado sobre a inflação, mas não sobre o emprego e o crescimento.

A segunda dificuldade se refere ao fato de que, no momento da tomada de decisão, informações relacionadas a variáveis econômicas podem estar defasadas ou imperfeitas. A posição da economia e do crescimento da demanda agregada só são conhecidos parcialmente, pois dados relevantes sobre o consumo, a produção e os preços estão sempre atrasados e sujeitos a revisão posterior.

Assim, os modelos econômicos são os recursos mais utilizados pelo Comitê para projetar a resposta da economia a uma política expansionista ou contracionista. Contudo, o impacto exato sobre o crescimento da demanda agregada nunca é certo, sendo o mesmo válido para a oferta agregada, a força de trabalho e o crescimento da produtividade.

Em síntese, os responsáveis pela política monetária tomam as suas decisões com base em dados estimados e relatos de contatos e participantes de diversos mercados. Mas não só essa política atua sobre a renda, o emprego, os preços, como também outras forças. Algumas podem ser antecipadas pelo Comitê, como um aumento de impostos ou a expansão de programas governamentais, enquanto outras são resultado de choques que alteram padrões de consumo de pessoas e empresas; e não podem ser previstos.

Por isso, aqueles que exercem o poder de voto no FOMC levam em consideração essas limitações, já que mudanças na taxa de juros só afeta a economia e os preços depois de certo tempo, e nem é simples determinar com exatidão qual o nível ou a trajetória ideal da taxa de juros que servirá aos objetivos de determinada política monetária. 
Desse modo, ao especificar uma meta para as taxas de juros, os membros do Comitê tendem a usar uma vasta gama de indicadores para verificar as tendências em vigor na economia doméstica, e internacional, a fim de melhor avaliar as alternativas disponíveis em política monetária. ${ }^{21}$

\subsection{Participantes, reuniões e documentos}

O Comitê de política monetária é formado pelos diretores do Board, pelo presidente do FRBNY e mais quatro presidentes de FRBs, que servem em caráter rotativo.

O Board é uma agência do governo federal que conta com sete membros indicados pelo presidente dos Estados Unidos e confirmados pelo Senado. Cada diretor serve por 14 anos, mas o início de cada período é escalonado, expirando sempre em 31 de Janeiro de cada ano ímpar. Um diretor não pode exercer o cargo por mais de um período, mas um membro escolhido para substituir um diretor que saiu antes do tempo determinado pode ser indicado novamente.

O presidente e vice-presidente do Board servem por quatro anos e também são escolhidos pelo chefe do Executivo e sabatinados pelo Senado. No entanto, os candidatos a essas duas funções devem fazer parte do Board. E por tradição, o presidente do Board é designado o presidente do FOMC, e o presidente do FRBNY, seu vice.

Os diretores do Board se reúnem duas vezes por mês e contam com uma equipe de aproximadamente 1.800 analistas e três comitês para auxiliar na supervisão e regulação das operações dos 12 FRBs, assegurar o funcionamento do sistema nacional de pagamentos e administrar as leis de proteção de crédito ao consumidor. Ademais, o

\footnotetext{
${ }^{21}$ Os principais instrumentos usados na formulação de política monetária são a regra de Taylor e as taxas de câmbio, já que a abordagem que usa agregados monetários perdeu bastante espaço desde 1982. A primeira, e mais importante, relaciona a taxa de juros a quanto a inflação está se distanciando de um nível de preços desejado, assim como, a quanto o produto da economia e o emprego estão se distanciando de um nível sustentável, ou do produto potencial.
} 
Board tem o papel de supervisionar e regular o sistema bancário norte-americano, junto com outras agências federais. ${ }^{22}$

Entre os demais formuladores de política, os diretores do Board estão em constante contato com membros do Council of Economic Advisers (CEA) e outros oficiais da área econômica do governo, o presidente dos Estados Unidos, o secretário do Tesouro, e também, com parlamentares - ao participarem em diversos comitês do Congresso.

O presidente do Board deve comparecer aos Comitês Bancário e de Serviços Financeiros, do Senado, pelo menos duas vezes ao ano, sempre por volta do dia 20 de fevereiro e do dia 20 de julho. O relatório Monetary Policy Report to the Congress é então apresentado, esclarecendo os esforços, atividades, objetivos e planos do Board e do FOMC a respeito de como a política monetária tem sido conduzida, os desenvolvimentos econômicos recentes do país e perspectivas para o futuro.

Este relatório é parte do Board's Annual Report, documento que reúne também as operações do FED, os registros com as ações políticas tomadas pelo Board e as atas das reuniões do FOMC. Além disso, inclui notas sobre a organização do sistema, tabelas estatísticas e auditorias realizadas.

Excetuando-se a política monetária, que é monitorada diretamente pelo Congresso através desses documentos, outros aspectos específicos das atividades do FED são revisados regularmente pelo Governamental Accountability Office (GAO), órgão independente do Executivo com mandato para auditar as contas do governo.

Já os FRBs são considerados os operadores do banco central, responsáveis por incluir operações no sistema de pagamentos nacional, distribuir notas e moedas, supervisionar e regular bancos membros e organizações bancárias, além de atuar como agentes fiscais do Tesouro norte-americano. ${ }^{23}$

\footnotetext{
22 Os diretores são assessorados, três ou quatro vezes por ano, pelo: Comitê Federal, com representantes da indústria bancária escolhidos por cada FRB, o Comitê de Consumo que reúne membros indicados pelo próprio Board e, o Comitê de Instituições de Poupança, composto por representantes de entidades de poupança, indicados também pelo Board.

${ }^{23}$ Os FRBs funcionam como o banco do governo dos Estados Unidos e realizam vários serviços para o Tesouro, demais agências públicas e government-sponsored enterprises ou GSEs. São devidamente reembolsados pelos custos dos serviços prestados. Os serviços para o Tesouro abrangem a manutenção de uma conta bancária para organizar recebimentos (impostos e empréstimos), processar pagamentos, emitir, guardar e transferir títulos (toda semana, mês e trimestre são realizados leilões para financiar e
} 
Cada FRB possui seu próprio Conselho com nove diretores, que representam os seguintes setores: bancário, comercial, agrícola, industrial e interesses públicos relacionados a cada Distrito. Três diretores representam exclusivamente os bancos comerciais membros do FED, sendo denominados Classe A. Os demais diretores representam os outros setores e o público, considerados então, Classes B e C.

Os bancos comerciais membros de FRBs elegem os diretores de Classe A e B, que não podem fazer parte de nenhum banco ou organização bancária. A Classe C é formada por diretores indicados pelo Board, e não podem possuir qualquer vínculo acionário com bancos ou organizações bancárias. O presidente e o vice-presidente devem ser selecionados entre aqueles que pertencem à Classe $C$, necessariamente, e uma vez nomeados pelos diretores do conselho regional, devem ser aprovados pelo Board.

Comitês agregam preferências individuais, devem ser liderados e tendem a adotar posições comprometedoras em questões difíceis o que explica em boa parte seu comportamento inercial. No caso do FOMC, cada um dos seus membros possui um voto, mas o presidente costuma exercer um poder significativo sobre o Comitê, que possui a tradição de decidir por consenso (BLINDER, 1999, p.20).

\begin{tabular}{|c|c|c|c|c|}
\hline \multicolumn{5}{|c|}{ Membros do FOMC: por ano (em 31 de Dezembro) } \\
\hline & 2008 & 2009 & 2010 & 2011 \\
\hline Presidente & Ben Bernanke & Ben Bernanke & Ben Bernanke & Ben Bernanke \\
\hline Vice & Timothy F. Geithner & William C. Dudley & William C. Dudley & William C. Dudley \\
\hline Board & Elizabeth A. Duke & Elizabeth A. Duke & Elizabeth A. Duke & Elizabeth A. Duke \\
\hline Board & Donald Kohn & Donald Kohn & Sarah B. Raskin & Sarah B. Raskin \\
\hline Board & Randall S. Kroszner & Daniel K. Tarullo & Daniel K. Tarullo & Daniel K. Tarullo \\
\hline Board & Kevin M. Warsh & Kevin M. Warsh & Kevin M. Warsh & Kevin M. Warsh \\
\hline Board & - & - & Janet Yellen & Janet Yellen \\
\hline FRB & Richard W. Fischer & Charles L. Evans & Jim Bullard & Charles L. Evans \\
\hline FRB & Sandra Pianalto & Janet Yellen & Sandra Pianalto & Richard W. Fischer \\
\hline FRB & Charles I. Plosser & Dennis P. Lockhart & Thomas M. Hoenig & Charles I. Plosser \\
\hline FRB & Gary H. Stern & Jeffrey M. Lacker & Eric S. Rosengren & Narayana Kocherlakota \\
\hline
\end{tabular}

Fonte: Elaborado pela autora com base ans atas de reuniões do Federal Open Market Committee (FOMC) entre 2008 e 2011.

Quadro 1 - Participantes do Federal Open Market Committee (FOMC), membros do Board e presidentes dos Federal Reserve Banks (FRBs).

refinanciar o governo). Além disso, os FRBs investem qualquer recurso extra do Tesouro em instituições depositárias, até quando necessário para efetuar operações do governo - facilitando também a implementação da política monetária.

Já bancos centrais estrangeiros e algumas organizações internacionais mantêm contas no FED para depósitos em dólar (sobre os quais não incidem juros), a guarda de títulos e de ouro. 
O quadro 1, aponta os membros do Comitê entre 2008-2011. A partir dele, é possível abordar as visões e forças em atuação dentro do FOMC, com base no histórico desses diretores e da administração que respondeu por sua indicação.

O principal cargo, de presidente do Board, foi ocupado por Ben Bernanke durante dois mandatos, de 2006 a 2014. Ele atuou durante grande parte de sua carreira como Professor na Universidade de Princeton - concluiu doutorado em economia e passou pelo Massachusetts Institute of Technology (MIT) e por Harvard. ${ }^{24}$

Os demais membros do Board do FED foram: Randall Kroszner, Donald Kohn, Kevin Warsh, Elizabeth Duke, Sarah Raskin, Daniel Tarullo e Janet Yellen. Esta última diretora assumiu a presidência do grupo com a saída de Bernanke, em 2014.

Aqueles nomeados pelo republicano George W. Bush, Kroszner, Kohn, Warsh e Duke desenvolveram carreiras distintas antes de exercerem o cargo de diretoria no FOMC. Em comum, muitos deles assessoraram comitês diversos do FED e do Executivo, ou, desempenharam funções de destaque na indústria bancária. ${ }^{25}$

Aqueles indicados pelo democrata Barack Obama, Raskin, Tarullo e Yellen participaram de atividades no banco central, trabalharam em alguma agência governamental ou atuaram na esfera acadêmica junto a universidades de prestígio. ${ }^{26}$

Presidentes do FRBNY entre 2008 e 2011, Timothy Geithner e William Dudley, ocuparam a vice-presidência do Comitê. Geithner atuou antes junto ao Departamento do Tesouro por três administrações diferentes (entre 1988 e 2001), de onde seguiu para o Fundo Monetário Internacional (FMI), até 2003. Já Dudley, trabalhou como economista-chefe

\footnotetext{
${ }^{24}$ Bernanke primeiro fez parte do FED como professor visitante nos FRBs de Philadelphia, Boston e Nova York, depois como assessor acadêmico a partir de 1990, até se tornar membro do Board em 2002. Também, exerceu o principal cargo na CEA, assessorando o presidente dos Estados Unidos entre 2005 e 2006.

${ }^{25}$ Kroszner foi professor, conselheiro na CEA e exerceu diversas funções dentro do FED. Kohn era um veterano do FED, tendo trabalhado em vários comitês internos e divisões da instituição. Warsh trabalhou no Morgan Stanley \& Co e também serviu a administração Bush. Duke foi diretora do Conselho do Reserve Bank de Richmond, presidente da Associação de Bancos da Virginia e membro da Associação Americana de Banqueiros, além de ter trabalhado em posições de destaque em bancos da região.

${ }^{26}$ Raskin trabalhou no FRBNY, no Comitê Econômico do Congresso, assessorando o comitê bancário do Senado e o Estado de Maryland, além de ter integrado a diretoria de um grupo financeiro. Tarullo se dedicou a atividade de professor na área do direito, como também, exerceu diversas funções no governo Clinton. Por fim, Yellen desenvolveu uma notória carreira na área acadêmica, serviu como membro do Board entre 1994-97 e presidiu o CEA. Ainda, ela coordenou os trabalhos de um dos comitês da OCDE até assumir a presidência do FRB de São Francisco.
} 
em um grande banco de investimentos por uma década, e também serviu como economista para o Board.

Antes das reuniões do FOMC, todos os participantes contam com diversos relatórios para auxiliar a tomada de decisão, sendo um deles elaborado pelos FRBs e os outros dois produzidos pelo Board:

(i) Beige Book, resume os comentários de cada FRB sobre as condições econômicas atuais do país, sendo publicado sempre duas semanas antes de cada reunião.

(ii) Greenbook, distribuído somente uma semana antes, discorre sobre as condições econômicas e financeiras atuais, contendo uma avaliação mais profunda da economia norte-americana e internacional. Pode ser dividido em três partes: um resumo e perspectiva da economia, os desenvolvimentos recentes e um suplemento com informações adicionais.

(iii) Bluebook, aponta três alternativas para a tomada de decisão de política monetária, além de contextos e panoramas a serem considerados na próxima reunião do Comitê.

Após essas reuniões, o FOMC anuncia as mudanças realizadas em política monetária e emite um comunicado para explicitar o raciocínio por trás de suas decisões. Essas práticas, entretanto, foram adotadas apenas a partir de 1995 e 1999, respectivamente.

Segundo o FRB de Dallas, a comunicação do Comitê evoluiu bastante ao longo dos últimos anos. Primeiro, ao mencionar um nível para a taxa de juros, depois um nível em torno de ou ao redor de um valor, e por fim, um nível alvo específico para a taxa de juros - principal instrumento de política monetária.

Esses comunicados continham entre 350 e 600 palavras entre 2008-2011, com informações a respeito da avaliação do Comitê sobre as condições econômicas, a perspectiva da economia, os fatores que poderiam acarretar em alguma mudança na 
política, e a relação dos votos de cada membro. A própria linguagem elaborada pelo FOMC também passou por modificações significativas ao longo desse tempo. ${ }^{27}$

O FED também costuma publicar as atas de cada reunião depois de três semanas, com maiores detalhes acerca dos tópicos tratados pelos participantes do Comitê. As transcrições dessas reuniões, entretanto, são liberadas para o público após cinco anos, no mínimo.

Mais recentemente, os membros do Comitê passaram a divulgar trimestralmente o Summary of Economic Projections (SEP), com uma avaliação sobre os riscos percebidos para a economia no futuro próximo. Com isso, o FOMC consegue colocar maior ênfase sobre o perigo de inflação, de deflação ou o fraco desempenho econômico.

Além dessas publicações, os membros do FOMC, do Board e dos FRBs realizam discursos, depoimentos e declarações, participam de conferências e publicam textos.

Já as reuniões em si, conforme a agenda habitual, compreende a aprovação de operações realizadas no mercado aberto e com moedas estrangeiras, a discussão da situação da econômica e da política monetária vigente, e por último, a confirmação da data do próximo encontro.

De forma geral, elas abordam cinco grandes tópicos. Os dois primeiros abrangem os desenvolvimentos do mercado, as operações do sistema no mercado aberto, os programas de liquidez e a avaliação do balanço do FED, podendo incluir discussões e a aprovação de propostas relacionadas a assuntos técnicos.

O terceiro tópico é uma revisão da situação econômica atual, apontando os diversos indicadores para a atividade econômica, o mercado de trabalho, a inflação e a evolução dos preços, a produção industrial, o consumo, os investimentos, o comércio internacional, o desempenho das economias avançadas e emergentes.

Também, são revisados os dados financeiros da economia, incluindo: o nível da taxa de juros estabelecido na última reunião e o impacto da decisão e do comunicado do FOMC, as expectativas de política monetária dos investidores e do mercado, as condições dos

\footnotetext{
${ }^{27}$ Fonte: Federal Reserve Bank of Dallas. Disponível em: <http://www.dallasfed.org/research/eclett/2013/el1308.cfm>. Acesso em: 10 jul. 2015.
} 
mercados de curto e longo-prazo, as condições de liquidez nos mercados monetários e a saúde das instituições financeiras.

A partir da quarta etapa, a equipe do FOMC apresenta as projeções para o produto da economia e a inflação para os próximos dois ou três anos, reforçando se as previsões foram modificadas para baixo ou para cima e as razões para tal.

A quinta etapa envolve as visões dos participantes sobre a economia atual, suas perspectivas para o crescimento do produto, do emprego e da inflação, além de um debate sobre a estratégia para a política monetária. Por fim, a ação política do Comitê é discutida somente entre os membros que possuem poder de voto, que então, assinalam os aspectos mais significativos a embasar a sua posição a favor ou contra as medidas expostas pelo presidente.

Cabe salientar que somente os cinco presidentes dos FRBs membros do FOMC podem exercer o voto, mas todos participam das reuniões do Comitê, contribuindo para a avaliação da economia e das perspectivas sobre as ações necessárias em política monetária.

Assim, entre os participantes estão membros do Board, presidentes dos FRBs, economistas, assistentes ou associados, o gerente do sistema da conta do mercado aberto do FRBNY (System Open Market Account ou SOMA), a equipe do Board, além de executivos dos FRBs.

\begin{tabular}{|c|c|c|c|c|c|c|c|c|c|}
\hline \multicolumn{10}{|c|}{ Datas das reuniões oficiais do FOMC } \\
\hline 2008 & & & & & & & 16 -set & & 15-dez \\
\hline 2009 & & 27-fev & 17-mar & 28-abr & 23-jun & 11-ago & 22-set & 3-nov & 16-dez \\
\hline 2010 & 26-jan & & 16-mar & 27-abr & 22-jun & 10-ago & 21-set & 2-nov & 14-dez \\
\hline 2011 & 25-jan & & 15-mar & 26-abr & 21-jun & & & & \\
\hline \multicolumn{10}{|c|}{ Datas das reuniões extraordinárias do FOMC } \\
\hline 2008 & & & & & & & 29-set & 7-out & \\
\hline 2009 & 16-jan & 7-fev & & 3-jun & & & & & \\
\hline 2010 & & & $9-a b r$ & & & & & & \\
\hline 2011 & & & & & 1-ago & 9-ago & & & \\
\hline
\end{tabular}

Aquelas reuniões que duraram dois dias foram destacadas em negrito, as demais duraram apenas um dia. Fonte: Elaborado pela autora com base nas atas das reuniões do FOMC entre 2008 e 2011.

Quadro 2 - Datas das reuniões oficiais e extraordinárias do Federal Open Market Committee (FOMC). 
Como apresentado no Quadro 2, entre 2008 e 2011, esses encontros contaram com 65 participantes em média, com no mínimo 55 e no máximo 80 pessoas. Nesse período, o Comitê se reuniu 30 vezes, oito a mais do que o regular. Desse total, 13 reuniões duraram dois dias, com discussões mais profundas acerca dos tópicos mencionados acima.

Essas discussões apontaram que a maioria dos votos em desacordo persistiram a favor de uma política econômica mais restritiva em nove das dez vezes em que pelo menos um membro votou contra as ações propostas pelo Comitê.

Em 28 de janeiro de 2009, Jeffrey M. Lacker do FRB de Richmond se posicionou contra a compra de dívida emitida por agências federais e de títulos lastreados em hipotecas, argumentando que ela distorcia o mercado de crédito. Durante todo o ano de 2010, Thomas Hoenig do FRB de Kansas City mostrou seu desagrado com a indicação do FOMC de que a taxa de juros deveria permanecer baixa por um período prolongado.

É incomum que mais de um membro manifeste sua posição contrária em determinada reunião, mas em 9 de Agosto de 2011, três membros divergiram em relação a decisão do Comitê, de especificar uma data, intervalo de tempo ou referência a um período em que a política monetária deveria permanecer acomodativa. Foram eles: Richard W. Fischer, Charles I. Plosser e Narayana Kocherlakota, dos FRBs de Dallas, Philadelphia e Minneapolis, respectivamente.

Além disso, o vice-presidente do FOMC e presidente do FRBNY, Timothy Geithner, não compareceu a duas dessas reuniões. Em 16 de setembro e 15 \& 16 de dezembro de 2008, ele foi representado pela Sra. Cumming, primeira vice-presidente do FRBNY.

No primeiro caso, Geithner estava envolvido com a crise financeira, liderando os esforços para encontrar uma solução para o Lehman Brothers. Já no segundo caso, ele havia sido apontado para ocupar o cargo de secretário do Tesouro do novo governo de Barack Obama, e decidiu se ausentar das deliberações do FED. ${ }^{28}$

\footnotetext{
${ }^{28}$ Fonte: WALL STREET JOURNAL. What are the responsibilities and powers of FOMC alternate members? >. 3 ago. 2015. Disponível em: <http://www.wsj.com/articles/what-are-the-responsibilitiesand-powers-of-fomc-alternate-members-1438637025>. Acesso em: 03 ago. 2015.
} 


\section{Departamento do Tesouro}

O Departamento do Tesouro norte-americano foi criado pela Lei 1 Stat.65 de 2 de Setembro de 1789. No entanto, muitas leis posteriores afetaram a agência, delegando novas responsabilidades e estabelecendo inúmeros escritórios e divisões.

O Tesouro está organizado atualmente em dois grandes blocos, 7 escritórios departamentais e 9 gabinetes operacionais. Os escritórios são responsáveis pela formulação da política e estão divididos em: o escritório de Finanças Domésticas, de Economia Política, de Terrorismo e Inteligência Financeira, de Assuntos Internacionais, de Política fiscal, o Tesouro dos Estados Unidos e o Fundo Comunitário para o Desenvolvimento de Instituições Financeiras.

O escritório de Estabilidade Financeira foi criado em Outubro de 2008, logo após a promulgação da Emergency Economic Stabilization Act of 2008 (EESA), para a implementação do Troubled Asset Relief Program (TARP). Também foi estabelecida uma Inspetoria Geral Especial para o TARP, responsável pela auditoria e investigação das operações de compra, gerenciamento e venda de ativos do programa.

Internamente, os escritórios departamentais são responsáveis pela administração do Tesouro, estando entre eles o de Gerenciamento e do Chefe Financeiro, o Conselho Geral, o de Assuntos Legislativos, de Assuntos Públicos e duas organizações de inspetoria geral - a Auditoria para a Administração Fiscal e o Escritório Geral do Auditor.

Já os gabinetes realizam operações específicas, e incluem, o gabinete de Impostos e Comércio de Álcool e Tabaco, de Gravação \& Impressão, da Dívida Pública, a Rede de Investigação de Crimes Financeiros, o Serviço de Gerenciamento Financeiro, Serviço Interno da Receita, a Casa da Moeda, a Controladoria Geral e o de Supervisão de Associações de Poupança.

As principais funções do Tesouro abrangem: gerenciar as finanças federais, arrecadar impostos e taxas e pagar todas as contas do governo, moeda e cunhagem, gerenciar as contas do governo e da dívida pública, supervisionar os bancos nacionais e as instituições de poupança, aconselhar as políticas financeiras doméstica e internacional, monetária, 
econômica, comercial e fiscal, reforçar as finanças federais e as leis fiscais, e investigar e processar sonegadores de impostos e falsificadores.

O Tesouro desempenha um papel fundamental para a economia dos Estados Unidos, ao gerenciar as finanças do governo, promover oportunidades econômicas por meio de uma política fiscal sólida, produzir reformas necessárias aos programas governamentais, fortalecer as políticas de comércio e investimento, e maximizar a coleta dos impostos.

O responsável por formular e administrar as políticas de impostos e financeira, doméstica e internacional, do governo dos Estados Unidos é o secretário do Tesouro. Ainda, ele deve recomendar e implementar as políticas econômicas e fiscais, doméstica e internacional, gerenciar as operações fiscais do governo, manter o controle dos ativos estrangeiros, administrar a dívida federal, recolher impostos sobre a renda e o consumo, representar os Estados Unidos em temas de moeda, comércio e investimentos internacional, supervisionar as operações dos departamentos e direcionar a fabricação de moedas, divisas e outros produtos para agências e o público.

Em julho de 2006, esse posto foi assumido por Henry M. Paulson Jr., após indicação do presidente George W. Bush. Antes disso, Paulson tinha desenvolvido uma carreira de 32 anos no banco de investimentos Goldman Sachs, onde serviu por oito anos como presidente e CEO. No Tesouro, reuniu um time de profissionais experientes e reinstituiu reuniões regulares do Grupo de Trabalho em Mercados Financeiros do Presidente. ${ }^{29}$

Entre os resultados obtidos, Paulson convenceu o Congresso a Ihe proporcionar poderes emergenciais sem precedentes para deter a crise, estabeleceu o G20 como o principal fórum de reforma financeira global e de recuperação econômica junto ao presidente Bush, e ajudou a criar o Diálogo Econômico Estratégico - alterando a natureza do engajamento dos Estados Unidos com a China. ${ }^{30}$

\footnotetext{
${ }^{29}$ Criado em 1988, o President's Working Group on Financial Markets (PWG) é o principal comitê formado por diversas agências governamentais federais responsável por coordenar a supervisão dos mercados financeiros e é composto pelo Secretário do Tesouro (que serve como Presidente), pelo Presidente do Conselho do Federal Reserve System, o Presidente da Comissão de Valores Mobiliários e o Presidente da Comissão responsável pela regulação dos mercados futuros e de opções. Fonte: U.S. DEPARTMENT OF THE TREASURY, Agency Financial Report FY 2008, p.11.

${ }^{30}$ G20 ou Grupo dos Vinte é o fórum para a cooperação no âmbito econômico internacional. Reúne anualmente os ministros das finanças e os presidentes dos bancos centrais de 19 países mais a União Europeia, e dedica-se a discutir como fortalecer a economia global, reformar as instituições financeiras
} 
Com o início da administração de Barack Obama em janeiro de 2009, Paulson foi substituído por Timothy F. Geithner, ex-presidente do FRBNY. Com o auxílio do FED e de um time de assistentes, Geithner foi reconhecido por desenvolver e executar uma série de programas para ajudar a recapitalizar e reestruturar o sistema financeiro e restaurar o crescimento econômico. Destacou-se por recuperar os investimentos feitos durante os programas financeiros emergenciais, tendo conseguido um significativo lucro para os contribuintes.

Também, empreendeu esforços para implementar um misto de cortes de impostos de curto-prazo e investimentos públicos para apoiar a economia durante a crise, seguido por reformas na área fiscal e de gastos de longo-prazo, a fim de colocar a situação fiscal do governo em uma base mais sólida.

Além disso, Geithner foi o principal idealizador do plano para reestruturar e reformar o regime financeiro, promulgado como Wall Street Reform and Consumer Protection Act e conhecido como Dodd-Frank Act. ${ }^{31}$

\subsection{Documentos emitidos pelo Departamento do Tesouro}

O Departamento Tesouro torna público diversas informações sobre as suas atividades. Em relação ao orçamento e ao desempenho da agência, existem quatro distintos grupos de documentos.

O primeiro se refere a esfera do Orçamento e abrange dois relatórios importantes: o próprio orçamento para o ano fiscal, que dá suporte a todo o trabalho que deve ser desenvolvido pela agência, e a Justificativa do Congresso para Apropriações ou Congressional Justification (CJ), que reflete as solicitações orçamentárias do presidente e inclui as prioridades da agência, as requisições de nível orçamentário e os planos de

internacionais, melhorar a regulação financeira e implementar reformas necessárias em cada país. Fonte: G20. Disponível em: < https://g20.org/about-g20/> Acesso em: 17 ago. 2015.

31 Fonte: U.S. DEPARTEMENT OF THE TREASURY. Disponível em: <http://www.treasury.gov/about/history/pages/hmpaulson.aspx> <http://www.treasury.gov/about/history/Pages/tgeithner.aspx>. Acesso em: 12 jun. 2015. 
desempenho. Por sua vez, o relatório intitulado Budget-in-Brief (BIB) contém um resumo dessas disposições.

O segundo grupo se refere a performance do Tesouro e seus documentos financeiros. $\mathrm{O}$ Relatório Financeiro da Agência ou Agency Financial Report (AFR) aborda os resultados financeiros e de desempenho para que o presidente, o Congresso e o público possam avaliar as realizações de cada ano fiscal - entre 1 de outubro e 30 de setembro. Publicado anualmente, este relatório inclui os programas, realizações, desafios e a prestação de contas dos recursos disponibilizados ao Tesouro. Ainda, a agência publica o Guia Anual do Cidadão para o Relatório Financeiro do Governo dos Estados Unidos (A Saúde Financeira do Governo Federal) e outros documentos oficiais, como: o Relatório do Gabinete de Estabilidade Financeira, o Relatório sobre as despesas de conferências e relacionadas, e o Relatório de Sustentabilidade Estratégica.

Em terceiro, estão os comunicados sobre a administração de dinheiro e da dívida, que englobam: o Comunicado Diário do Tesouro ou Daily Treasury Statement (DTS), o Comunicado Mensal do Tesouro com as despesas e recebimentos do Governo ou Monthly Treasury Statement (MTS) e o Comunicado Mensal do Tesouro sobre a dívida Pública ou Monthly Statement on Public Debt (MSPD).

O relatório completo sobre o custo das operações e os recursos utilizados para financiar o governo estão no The Financial Report of the United States Government. Esse documento aponta a condição e a posição financeira atual dos Estados Unidos, receitas e custos, recursos disponíveis, obrigações e outras responsabilidades e compromissos assumidos. Além disso, proporciona análises sobre os possíveis cenários futuros e um panorama da sustentabilidade fiscal.

O quarto e último grupo diz respeito aos planos estratégicos. Elaborado a cada cinco anos, o plano representa os objetivos do departamento de acordo com as diversas atividades que permitem a agência efetivamente administrar as finanças do país, promover oportunidades na economia e no emprego, fortalecer a segurança nacional e atingir a excelência organizacional. 
Dois desses objetivos se destacam entre os demais: o desempenho econômico dos Estados Unidos e do mundo em todo o seu potencial, e, a manutenção da confiança na moeda norte-americana em todo o mundo.

Em relação ao primeiro objetivo, o Tesouro coloca como essencial melhorar as oportunidades econômicas, a mobilidade e a segurança por meio de um crescimento econômico sustentável, real e sólido no âmbito doméstico e internacional. Como resultado, espera que o departamento seja capaz de prevenir e mitigar crises econômicas e financeiras quando ocorrerem, ao promover políticas pró-crescimento e de resolução de problemas; assim, ajudando a reter os benefícios do progresso econômico, reduzir a pobreza, manter a estabilidade política e evitar intervenções custosas.

Nesse sentido, o Tesouro busca especificamente estimular o crescimento do país, fortalecer e modernizar os programas do governo, participar da diplomacia econômica e financeira, fortalecer os mercados e as instituições financeiras, encorajar o cumprimento voluntário de recolhimento de impostos e promover a educação financeira.

O segundo objetivo, manter a confiança na moeda norte-americana, é considerado vital para permitir um comércio transparente e estável. O Tesouro é responsável por prover notas e moedas seguras, com custo eficiente, de qualidade e aceita por todos - usuários e clientes.

Dessa forma, a agência procura responder às exigências de seus clientes ao adaptar a sua capacidade produtiva, participar de pesquisas e desenvolver medidas contra falsificações, promover o combate global a moedas falsas, estender a vida útil das notas e utilizar materiais alternativos.

Formulado em julho de 2007, o documento também observa que as operações do Tesouro são influenciadas por uma série de fatores que não estão diretamente sob o seu controle. Com isso, identifica certos pontos críticos. ${ }^{32}$

Alguns desses pontos estão relacionados ao rápido crescimento dos gastos do governo, ao aumento do número de aposentados, de imigrantes, a necessidade de acompanhar

\footnotetext{
32 Os pontos críticos levantados pelo plano estratégico de 2007-2012 abrangem: ambiente orçamentário, tecnologia, força de trabalho, cooperação, economia, serviços financeiros, globalização, legislação, sociedade, ameaças à segurança nacional e imigração.
} 
constantemente a percepção do público em relação ao governo. Como exemplo, podese citar as alterações demográficas, que pressionam o serviço de seguridade social e o sistema de saúde.

Um ponto, em especial, reconhece que os mandatos legislativos afetam o trabalho do departamento, e que os limites impostos sobre o total da dívida podem restringir a habilidade do Tesouro em pegar emprestado e financiar as atividades do governo federal. Assim, muitas das suas ações, dependem do consenso político e de uma legislação eficiente.

Considerados desafios regulatórios, outros pontos se referem a consolidação de instituições, a variações na taxa de poupança e o desenvolvimento de novos produtos e serviços financeiros, do aumento no escopo do sistema financeiro e os efeitos da globalização na economia - que acarretam em uma maior dificuldade para manter o ambiente moderno e promover a estabilidade financeira. Ademais, reconhece a imprevisibilidade de crises financeiras e econômicas, e a necessidade de adotar de políticas eficazes frente a esses episódios. ${ }^{33}$

\section{A interação entre as políticas monetária e fiscal}

As iniciativas de política, medidas adotadas e reações suscitadas pelo FED e o Tesouro no período que compreende o auge da crise financeira e o impasse da elevação do teto da dívida foram diversas. Ainda, muitos dos programas propostos passaram por revisões e reformulações, sendo significativamente ampliados, estendidos e modificados ao longo do tempo. ${ }^{34}$

Tratou-se de um amplo conjunto de medidas de política monetária e fiscal que foi sendo reformado de acordo com as necessidades econômicas e/ou com as possibilidades

\footnotetext{
${ }^{33}$ Os demais pontos estão ligados ao comercio eletrônico e à segurança, à necessidade de cooperação contra o terrorismo, a proliferação e armas de destruição em massa, o tráfico de drogas, o crime internacional e o mercado negro.

${ }^{34}$ Ver Quadros A-1 e A-2 do Apêndice.
} 
políticas. Interessa a este trabalho analisar o papel de cada uma destas instituições na elaboração e implementação destas políticas.

Após o exame de cada uma das medidas implementadas durante o período em foco, foi possível reuni-las em quatro grandes grupos: empréstimos de curto-prazo a instituições financeiras, provisão de liquidez a mercados específicos, assistência direcionada e gerenciamento do portfólio do FED.

Para além dos documentos oficiais produzidos pelas instituições, os inúmeros discursos, depoimentos, declarações e artigos elaborados pelo presidente do FED e pelos chefes da agência do Executivo no período ajudam a esclarecer os propósitos e as justificativas apresentadas pelas entidades para o desenvolvimento de suas políticas. Assim, a posição adotada por Bernanke, Paulson e Geithner pode ser identificada nos comunicados.

Em geral, a maior parte dessas comunicações (204) foram realizadas por Geithner entre 2010 (73) e 2011 (36). A agência esteve constantemente preocupada em explicitar e defender as suas decisões perante o público e os políticos, através de declarações (98) e depoimentos (30).

O secretário do Tesouro só foi superado por Bernanke no segundo semestre de 2008 e no ano de 2009, com um total de 10 e 23 comunicados, respectivamente. O presidente do FED realizou discursos em conferências e associações, dialogando essencialmente com investidores e empresários atemorizados pela crise. Além disso, das 22 vezes que Bernanke testemunhou nesse período, quatro foram em função do relatório semianual obrigatório preparado pelo banco central ao Congresso.

Tendo em mente tanto esses dados e as categorias apresentadas acima, procurou-se primeiro descrever as principais medidas empregadas por essas duas instituições, para, em seguida, apontar quais foram os pontos de convergência e divergência entre as políticas adotadas.

\subsection{Empréstimos de curto-prazo a instituições financeiras}


Term Securities Lending Facility (TSLF). Criado pelo FED em março de 2008, tinha como propósito conceder empréstimos de até USD 200 bilhões de títulos do Tesouro para negociadores primários, por 28 dias. As garantias aceitas eram os títulos do Tesouro, as dívidas e títulos MBS de agências federais, e AAA/Aaa MBS residenciais. Em setembro de 2008, o FOMC autorizou a expansão das garantias elegíveis, aumentou o tamanho e a frequência dos leilões e relaxou temporariamente as limitações para corretoras acessarem os fundos das instituições depositárias associadas ao sistema do FED.

Primary Dealer Credit Facility (PDCF). Estabelecido pelo FED também em março de 2008, buscou melhorar a capacidade de negociadores primários em prover financiamento a participantes do mercado de securitização. Com prazo inicial de seis meses, foi expandido em setembro de 2008 e prorrogado até 30 de outubro de 2009.

Term Auction Facility (TAF). Foi implementado em dezembro de 2007 pelo Board devido ao estigma relacionado à janela de redesconto. Visava leiloar uma série de recursos a instituições depositárias contra uma grande variedade de garantias, que poderiam ser usadas para realizar empréstimos na janela de redesconto. Em outubro de 2008, o FED eleva para USD 900 bilhões o crédito disponível, com 28 e 84 dias de vencimento, e anuncia mais dois leilões para até o fim do ano. Em janeiro de 2009, o FED substitui a taxa cobrada, de overnight index swap (OIS) para a taxa paga sobre as reservas bancárias em excesso (IOER).

Temporary reciprocal currency arrangements (swap lines). No final de 2007, é autorizada a realização de acordos de moeda recíprocos com determinados BCs estrangeiros por um prazo de seis meses. Em setembro de 2008, o FED estende e amplia esses acordos com economias desenvolvidas e aquelas associadas ao NAFTA. Mais tarde, elimina o limite quantitativo formal para as linhas de swap com os BCs do Japão e da Inglaterra e estabelece novas linhas com BCs de países emergentes (em complementariedade a ações adotadas pelo FMI).

Em maio de 2010, a pedido dos principais BCs europeus, o FOMC aprova resolução reestabelecendo acordos com os BCs da Inglaterra, Suíça, Japão, Canadá e o Banco Central Europeu (BCE). Essa ação refletiu preocupações do mercado com a Grécia e outros países da zona do euro. Dessa vez, o Comitê colocou a necessidade de consulta a oficiais do governo e enfatizou a necessidade de ações efetivas e fortes das autoridades, visando a sustentabilidade fiscal e o apoio aos mercados financeiros. Os acordos são estendidos até 31 de janeiro de 2011, e novamente, até 1 de agosto de 2011.

Interest rate on required and excess reserves (IORR e IOERR). A seção 128 do Emergency Economic and Stability Act (EESA) autorizou o FED a pagar juros sobre os saldos mantidos por instituições depositárias nos FRBs, e a reduzir o nível de reservas obrigatórias em contas de transação. Após as mudanças necessárias a Regulação D, o Board anuncia as medidas para promover um maior controle do fed funds. Em outubro e novembro de 2008, o Board aprova alterações nas fórmulas usadas para determinar os juros pagos e em dezembro, e estabelece essa taxa em $0,25 \%$ sobre o fed funds. 
Supplementary Financing Program (SFP). Programa criado pelo Tesouro, a pedido do FED. O Tesouro passou a emitir títulos de curto-prazo além e acima do programa de empréstimo regular, depositando os proventos no FED, ou seja, aumentando significativamente os saldos em dinheiro à disposição do banco central.

Com o avanço das turbulências, o presidente do FED passou a adotar um tom cada vez mais alarmante, sinalizando diversas vezes as implicações adversas para a economia em função dos desafios, incertezas, estresse e condições extraordinariamente turbulentas dos mercados financeiros.

Como resposta, a instituição expandiu os empréstimos existentes com o intuito de prover liquidez aos bancos comerciais e negociadores primários, através do TSLF, PDCF, swap lines, e do TAF. Os prazos de financiamento foram estendidos a até 90 dias, o número de leilões e o volume ofertado aumentaram, outros ativos passaram a ser aceitos como garantia para a realização de empréstimos.

No âmbito internacional, o Board expandiu acordos de swap com bancos centrais estrangeiros a fim de atender a demanda crescente de dólar no mercado externo, proporcionando maior liquidez a esses mercados de financiamento e contribuindo para aliviar a pressão sobre o mercado doméstico. ${ }^{35}$

Nesta primeira etapa, os novos mecanismos criados foram o pagamento de juros sobre reservas bancárias, e o SFP. Com a aprovação da legislação emergencial, o FED alterou a taxa cobrada para realizar grande parte de suas operações, provendo um piso para o fed funds.

Por sua vez, o programa de financiamento suplementar (SFP) permitiu ao FED, efetivamente, gerenciar a expansão de seu balanço, ao compensar as reservas provisionadas no sistema bancário por meio dos seus inúmeros instrumentos de liquidez.

Em dezembro de 2008, o Tesouro chegou a anunciar que não iria rolar títulos relacionados a esse programa, a fim de preservar certa flexibilidade na condução da

\footnotetext{
${ }^{35}$ Outros dois importantes movimentos de coordenação internacional foram, em outubro de 2008 e em março de 2011. No auge da crise, os BCs de diversas economias desenvolvidas anunciaram em conjunto a redução da taxa de juros em seus respectivos países. E após o terremoto/tsunami no Japão, o BC desse país injetou um volume recorde de liquidez e expandiu o programa de compra de ativos para frear a valorização do yen - atingiu a sua maior cotação contra o dólar. Porém, esse movimento somente foi revertido com a intervenção coordenada de $\mathrm{BCs}$ dos países do $\mathrm{G}-7$, para vender yen.
} 
política de gerenciamento da dívida. Mas essa decisão foi revisada, dada a incerteza gerada sobre a oferta desses títulos, exacerbando ainda mais os problemas de liquidez do mercado.

Dessa forma, os empréstimos realizados pelo Tesouro ao FED chegaram a USD 300 bilhões, com impacto direto sobre o déficit orçamentário, que saltou de USD 163 bilhões para USD 455 bilhões em 2008. Esse número representava 1,2\% do PIB em 2007, 3,2\% do PIB em 2008 e atingiu 10\% em 2009, um avanço de 213\% em apenas três anos.

Com a ajuda da tabela 1, é possível perceber a mudança no padrão do governo. Pela primeira vez, o custo operacional líquido ultrapassou o valor de USD 1 trilhão, representando quase três vezes o custo verificado em 2007, ou 266\%. A tendência de expansão dos gastos se manteve em 2009, mais fraca, e em 2010, mais forte, sendo revertida somente no ano seguinte. Apesar da queda de 37\%, o custo em 2011 permaneceu em um patamar bem mais alto se comparado ao ano anterior à crise.

A posição líquida do governo federal foi se deteriorando bastante durante esse período. Em 2010, verifica-se uma piora de 18\% em comparação a 2009. Essa diferença, entretanto, não se refletiu no déficit orçamentário unificado. Em relação ao PIB, esse número caiu tanto em 2010 como em 2011.

Tabela 1 - A Condição \& Posição Financeira do Governo dos Estados Unidos entre 20072011, componentes selecionados.

A Condição \& Posição Financeira do Governo dos Estados Unidos entre 2007-2011, componentes selecionados

\begin{tabular}{lccccc} 
Item (bilhões de dólares) & 2007 & 2008 & 2009 & 2010 & 2011 \\
\hline Custo operacional líquido & 275,5 & $1.009,1$ & $1.253,7$ & $2.080,3$ & $1.312,6$ \\
Total de ativos & $1.581,1$ & $1.974,7$ & $2.667,9$ & $2.883,8$ & $2.707,3$ \\
Total de passivos & $-10.786,9$ & $-12.178,2$ & $-14.123,8$ & $-16.356,6$ & $-17.492,7$ \\
\hline Posição líquida & $-9.205,8$ & $-10.203,5$ & $-11.455,9$ & $-13.472,8$ & $-14.785,4$ \\
\hline
\end{tabular}

Resultado Orçamentário:

$\begin{array}{llllll}\text { Déficit orçamentário unificado } \quad 162,8 \quad 454,8 & 1.417,2 & 1.294,1 & 1.298,6\end{array}$

$\begin{array}{llllll}\text { como } \% \text { do PIB } & 1,2 \% & 3,2 \% & 10,0 \% & 9,0 \% & 8,7 \%\end{array}$

Fonte: elaborado pela autora com base em The Financial Report of the United States Government, entre 2008-2011.

Todavia, a posição financeira do governo de 2008 refletiu a tentativa das autoridades em atender as necessidades de liquidez de participantes bancários. Diante desse diagnostico 
inicial, o banco central deveria exercer sua função de emprestador de última instância para que os mercados voltassem a funcionar normalmente.

O primeiro entrave a essa política apareceu com o estigma relacionado à janela de redesconto, contornado pelo FED com a criação de diversos novos programas com a mesma função, basicamente.

Já o segundo entrave esteve relacionado aos participantes não-bancários em mercados de financiamento de curto-prazo. Nesse sentido, tanto o Tesouro como o FED buscaram alternativas para atender a essa nova demanda, demonstrando um alto grau de flexibilidade com a implementação de novas políticas emergenciais.

\subsection{Provisão de liquidez, garantia e capital a mercados específicos}

Asset-backed Commercial Paper Money Market Fund Liquidity Facility (AMLF). Criado pelo FED em setembro de 2008, o programa amplia os empréstimos a taxas de crédito primário para instituições depositárias e bancárias para financiar a compra de notas promissórias lastreadas por ativos de alta qualidade ou assetbacked comercial paper (ABCP) de fundos mútuos no mercado monetário. Com prazo inicial de seis meses, foi estendido até 30 de Outubro de 2009.

Commercial Paper Funding Facility (CPFF). Foi criado pelo FED em outubro de 2008 para prover um respaldo de liquidez para os emissores norte-americanos de notas promissórias bem avaliadas. O crédito era providenciado através de um veículo de propósito especial ou special vehicle purpose (SPV) que, por sua vez, compra papéis comerciais não-segurados e ABCPs de três meses de emitentes qualificados. Contou com a participação das nove maiores instituições financeiras do país.

Money Market Investor Funding Facility (MMIFF). Permitiu ao FED prover financiamento a uma série de SPVS, dando suporte a inciativa promovida pelo setor privado de financiar a compra de determinados certificados de depósito bem avaliados, notas bancárias e notas promissórias do mercado de fundos mútuos e entidades similares. O programa foi encerrado em 30 de Outubro de 2009.

Temporary Guarantee Program for Money Market Mutual Funds. O programa consistia no pagamento de uma taxa determinada de acordo com valor líquido por ativo em 19 de Setembro. Os acionistas dos fundos recebiam a garantia de que seriam compensados em até USD 1 do preço do ativo do fundo, caso esse preço caísse para menos de USD 0,995. O valor inicial de USD 50 bilhões foi financiado pelo Exchange Stabilization Fund (ESF) e chegou a garantir 93\% dos fundos mútuos do mercado monetário, cobrindo USD 3.62 trilhões em ativos. 
Foi criado para atender fundos tributados e não tributados regulados pela SEC, sob a Investment Company Act of 1940, com o objetivo de reverter as perturbações nesses mercados por um período inicial de três meses. O programa foi encerrado em setembro de 2009 e o governo recebeu USD 1.2 bilhões em taxas, sem qualquer prejuízo.

Temporary Guarantee Program (TGLP). O secretário do Tesouro assinou uma exceção de risco sistêmico em outubro de 2008, permitindo ao FDIC garantir temporariamente todos as dívidas sêniores nãoseguradas de instituições bancárias e entidades associadas a agência, como também, os saldos em conta que não recebem juros. Com o EESA, essa cobertura é estendida de USD 100,000 para USD 250,000 e, para tanto, o FDIC poderia realizar empréstimos com o Tesouro além do autorizado pelas seções 14(a) e 15(c) do Federal Deposit Insurance Corporation Act. Em outubro de 2009, o FDIC estende o programa com restrições, devido à baixa procura.

Emergency Economic Stabilization Act of 2008 (EESA). Assinada em outubro de 2008, a lei disponibilizou recursos para a expansão do programa de compra de MBS, criou um programa de empréstimos geral, um programa de seguro para ativos tóxicos e um programa de compra de ações. Com vigência até 31 de dezembro de 2009, o EESA aumentou o limite estatutário da dívida pública em USD 700 bilhões, de USD 10.615 trilhões para USD 11.315 trilhões.

Troubled Asset Relief Program (TARP). Principal programa do EESA, autorizou o Tesouro a comprar até USD 250 bilhões em ativos, disponibilizou mais USD 100 bilhões mediante ao envio ao Congresso de certificação por escrito do presidente, e outros USD 350 bilhões, mediante requisição do presidente detalhando os planos do secretário para exercer essa autoridade adicional - desde que o Congresso não promova lei que remova a autoridade do presidente. Além disso, providenciou uma série de proteções aos interesses de contribuintes, exigências de que os participantes fornecessem uma parte do controle dos seus negócios para o governo, restringissem os pagamentos a executivos e cláusulas restritas em relação a seleção de gerentes de ativos. O TARP foi estendido pelo secretário até 3 de outubro de 2010.

Term Asset-Backed Securities Loan Facility (TALF). Programa criado em novembro de 2008 para apoiar o mercado de títulos lastreados por ativos colateralizados de empréstimos. Orginalmente constituído para absorver empréstimos estudantis, de automóveis e de cartão, tinha como propósito destravar os mercados de crédito para famílias e empresas. O FED compraria até USD 200 bilhões em títulos lastreados em ativos ou asset-backed securities (ABS) AAA garantidos por novos e recém originados empréstimos para consumidores e empresas. Já o Tesouro comprometeria USD 20 bilhões, para o caso de inadimplência.

American Recovery and Reinvestment Act of 2009 (ARRA). Sob o ARRA, segundo pacote fiscal do governo de USD 787 bilhões, o Tesouro administrou dinheiro para assistência, pagamentos em créditos de impostos 
e mais de 50 provisões de abatimento de impostos, entregando mais de USD 300 bilhões para famílias e empresas. $^{36}$

Financial Stability Plan (FSP). Em fevereiro de 2009 o secretário do Tesouro anuncia uma série de iniciativas para ajudar no fortalecimento da recuperação econômica, na prática realizando uma revisão do TARP. Além de exigências de maior transparência e prestação de contas, o plano contou com cinco grandes iniciativas:

Consumer \& Business Lending Initiative. Lançado em conjunto com o FED, o Tesouro buscava implementar, ampliar e expandir substancialmente o TALF com os recursos do TARP. O programa passaria a abranger até USD 1 trilhão em novos e recentes ABS AAA, lastreados por quatro tipos adicionais de empréstimos para consumidores e empresas, incluindo o commercial morgtgagebacked securities (CMBS) e o private-label residential MBS. O TALF é estendido pelo FED até 31 de Março de 2010 para novos ABS e CMBS, e 30 de Junho de 2010 para novos CMBS. Em julho de 2010, o Tesouro reduz seu compromisso sob o programa para USD 4.3 bilhões.

Unlocking Credit for Small Business Initiative. O Tesouro disponibilizou USD 15 bilhões de recursos do TARP para realizar compras diretas a fim de destravar o mercado secundário para uma porção de empréstimos do SBA 7(a) garantidos pelo governo, bem como hipotecas de primeira linha através do programa 504. O programa foi lançado em março de 2009 e um ano depois.

Housing Support and Foreclosure Prevention. Seria um amplo programa para estabilizar o mercado imobiliário, ao encorajar taxas hipotecárias mais baixas e tornar mais fácil o acesso de milhões ao refinanciamento e evitar despejos.

Capital Assistance Program (CAP). Desenvolvido para assegurar a habilidade de instituições continuarem a emprestar a tomadores confiáveis, o CAP englobava um exercício de supervisão e um programa de acesso a novo capital. Em maio de 2009, o Supervisory Capital Assessment Program (SCAP) foi publicado com os resultados das avaliações (stress tests) realizadas nos 19 maiores bancos do país. Os bancos aprovados teriam acesso ao programa de capital do Tesouro, em parceria com o FDIC e o FED. Esses recursos deveriam absorver perdas e servir de ponte para obtenção de capital adicional em mercados privados, um "capital buffer". Qualquer investimento sob o CAP seria feito por uma entidade separada, a Financial Stability Trust, SPV instituída para realizar investimentos do governo em instituições financeiras norte-americanas.

\footnotetext{
${ }^{36}$ O ARRA contou com os seguintes programas: o Making Work Pay Credit, Expanded tax break for 2009 first-time home-buyers, American Opportunity Credit, COBRA Health Insurance Continuation Premium Subsidy, Build America Bonds (BAB), Sales tax deduction for vehicles purchases, Economic Recovery Payments, Community Development Financial Institutions (CDFI) awards, New Markets Tax Credit (NMTC), Health Coverage Tax Credit (HCTC), Payments for Specified Energy Property in Lieu of Tax Credits e Payments for Low-Income Housing Projects in Lieu of Tax Credits.
} 
Public-Private Investment Program (PPIP). O Tesouro, o FDIC e o FED buscaram prover um mercado para ativos e títulos tóxicos que afetavam o balanço de instituições financeiras. O programa deveria comprar USD 100 bilhões de ativos, valor depois reduzido para USD 30 bilhões.

Hiring Incentives to Restore Employment Act of 2010 (HIRE). Aprovada em abril de 2010, a lei provê aos empregadores um incentivo para empregar trabalhadores que estiveram desempregados por 60 dias ou mais.

Small Business Jobs Act of 2010 (SBA). O Tesouro empreendeu esforços para passar essa lei que deveria fortalecer a capacidade de pequenas empresas a criar empregos e apoiar a recuperação da economia. O Small Business Lending Fund (SBLF) contava com USD 30 bilhões em capital para pequenos bancos, e o State Small Business Credit Initiative (SSBCI) com USD 1.5 a USD 2 bilhões, para incentivar o uso de USD 20 bilhões em empréstimos do setor privado em programas estaduais.

As alternativas encontradas pelo Tesouro se concentraram na ampliação de garantias oferecidas pelo governo, por meio do Temporary Guarantee Program for Money Market Mutual Funds e do TGLP. Sem respaldo do Legislativo, a agência não poderia utilizar o dinheiro dos contribuintes para restaurar a estabilidade dos mercados e a confiança do investidor.

Nesse sentido, o banco central era a única instituição com capacidade para agir, por meio da seção 13(3) do Federal Reserve Act, dispositivo que permitia a uma maioria formada por cinco membros do Board autorizar FRBs a emprestar a indivíduos, empresas e corporações em "unusual and exigent circumstances". ${ }^{37}$

Sob essa autoridade, o FOMC e o Board desenvolveram programas emergenciais para estabilizar os mercados de negociadores de títulos primários, os mercados monetários de fundos mútuos e outros mercados de financiamento de curto-prazo. Entre eles estão o AMLF, o CPFF e o MMIFF.

Esses programas representaram uma prática inovadora e sem precedentes para o banco central norte-americano. As suas atividades não estariam mais restritas ao sistema bancário, mas englobariam qualquer mercado onde ocorresse de fato a intermediação

\footnotetext{
${ }^{37}$ A seção 128 do EESA estabeleceu que o Board do FED deveria submeter relatório a comitês do Congresso, no máximo sete dias após conceder qualquer empréstimo a indivíduo, empresa ou corporação sob a autoridade da seção 13(3) do Federal Reserve Act. Fonte: Federal Reserve Board. 95th Annual Report, p.199.
} 
financeira e a distribuição de crédito. Para o presidente do FED, "[...] tempos extraordinários pedem medidas extraordinárias". ${ }^{38}$

Nesse sentido, Kohn (2010) esclarece que a divisão de responsabilidades entre as autoridades monetária e fiscal apresentou desafios. Ao banco central, não é apropriado prover capital diretamente, devendo somente financiar instituições solventes mediante boas garantias. Porém, ao buscar limitar o pânico, a atuação do FED também mitigou a erosão do preço de ativos e de capital nos mercados de securitização.

Apenas com o TALF, ficaram definidas as funções de cada entidade. De um lado, o FED disponibilizava empréstimos e o Tesouro, de outro, assumia o risco de crédito. 0 programa foi criado em conjunto pelas duas instituições, a partir da assinatura do EESA.

Essa lei emergencial foi o resultado de um projeto apresentado pelo Tesouro, em tom de urgência, tendo como foco a compra de ativos tóxicos lastreados por hipotecas em mercados de crédito, principal intermediário das atividades de financiamento de capital para empresas. Perante o Congresso, o secretário do Tesouro afirmava que as turbulências no mercado teriam efeito sobre o contribuinte e as ferramentas à disposição do governo eram variadas, mas insuficientes para lidar com a crise - "[...] um tipo diferente de resposta política era necessária". ${ }^{39}$

A solução deveria então ser legislativa, por meio de um programa sem precedentes com uma abordagem audaciosa; única saída para manter a saúde da economia, prevenir a falência de outras instituições financeiras e o congelamento dos mercados de crédito.

O apoio do FED seguiu essa mesma linha, ao defender uma ação rápida dos parlamentares. Para evitar um colapso financeiro internacional era fundamental lidar com essa crise o mais rápido possível. Por isso, quando o projeto é rejeitado, o secretário do Tesouro confessa seu desapontamento, "[...] isso é muito importante para simplesmente falhar". ${ }^{40}$

\footnotetext{
${ }^{38}$ Fonte: FED Chairman Ben Bernanke at the National Press Club, Washington D.C. "Federal Reserve Policies to Ease Credit and Their Implications for the Fed's Balance Sheet". February 18, 2009. Tradução nossa.

${ }^{39}$ Fonte: U.S. DEPARTMENT OF THE TREASURY, The Federal Government's Financial Health 2009, p. 18. Tradução nossa.

${ }^{40}$ Fonte: Statement by Secretary Henry M. Paulson, Jr. on Emergency Economic Stabilization Act Vote. September 29, 2008. Tradução nossa.
} 
Essa era uma referência a fragilidade do sistema financeiro, a ameaça ao bem-estar da economia e a necessidade de uma legislação simples e forte em um curto período de tempo. Seria um sinal claro aos investidores de que os Estados Unidos estavam comprometidos em tomar as ações necessárias para proteger o sistema.

Aprovado em tempo recorde, o EESA buscou prover imediatamente autoridade e recursos para o secretário do Tesouro, assegurar que tal autoridade e recursos fossem utilizados de maneira a proteger o valor das casas, os fundos escolares, as pensões e as poupanças, preservar a manutenção dos imóveis e promover o crescimento de empregos e da economia; maximizar o retorno aos contribuintes e prestar contas pelo exercício dessa autoridade.

O plano fiscal permitiria ao Tesouro, em conjunto com o FED e o FDIC, tomar atitudes decisivas para proteger a economia norte-americana. Ao mesmo tempo, o secretário do Tesouro assinalava, "[...] nós lamentamos ter de tomar essas ações [...] mas as ações de hoje são o que nós precisamos fazer para restaurar a confiança ao nosso sistema financeiro". ${ }^{41}$

Diferentemente do que foi proposto no TARP, principal programa do EESA, o Tesouro decidiu disponibilizar USD 250 bilhões em capital para instituições financeiras na forma de ações preferenciais. Contou com a participação das nove maiores instituições financeiras do país para incentivar as demais a aceitarem esses recursos também.

Entretanto, ao anunciar que os fundos do TARP não seriam usados para a compra de ativos, o Tesouro estimulou reações negativas nos preços, com uma intensa onda de vendas nesse mercado específico, sob a visão do FED. Deste modo, apesar de evitar uma depressão, o TARP não conseguiu resolver todos os problemas relacionados aos ativos tóxico, ou combater a vulnerabilidade e a desconfiança dos mercados.

Assim, pouco depois de promulgado o EESA, o presidente do FED ressalta que um segundo pacote fiscal seria apropriado, dado o risco de uma retração econômica mais

\footnotetext{
${ }^{41}$ Fonte: Statement by Secretary Henry M. Paulson, Jr. on actions to protect the U.S. economy. October 14, 2008. Tradução nossa.
} 
duradoura. Consumidores, investidores de imóveis, pequenas empresas e até mesmo governos locais e estaduais enfrentavam dificuldades para obter crédito.

Aprovado em janeiro de 2009, quando a nova administração assumiu o governo, o ARRA foi considerado um esforço sem precedentes para recuperar a economia. Esse segundo plano fiscal permitiu ao secretário do Tesouro divulgar uma série de iniciativas para ajudar no fortalecimento da recuperação econômica, o que na prática significou uma revisão do TARP.

Rebatizado de Financial Stability Plan (FSP), o plano contou exigências de maior transparência e prestação de contas. Tinha como finalidade destravar os mercados de crédito e ajudar a prover maior confiança aos tomadores de empréstimos, interferindo diretamente nos mecanismos de intermediação. Outros instrumentos também foram desenhados para ajudar instituições bancárias e não-bancárias, provendo auxílio com investimento e capital a algumas entidades.

Além disso, duas novas leis tiveram impacto direto sobre as atividades do Tesouro, o HIRE e o SBA. Entre seus objetivos estavam: prover maiores estímulos aos gastos de famílias e pequenas empresas ou reformular políticas fiscais, tendo como base iniciativos do próprio departamento, como a Small Business and Community Lending Initiative, criada para evitar a queda de empréstimos SBA 7(a), principal linha de crédito de pequenas empresas e bancos comunitários.

As inovações realizadas pelas autoridades monetária e fiscal, portanto, visaram atender todos os mercados de financiamento de curto-prazo, responsáveis pelo crédito a empresas e famílias. Com a intensificação da crise, os investidores passaram a buscar a segurança dos títulos do Tesouro norte-americano, reduzindo acentuadamente o volume de operações com notas promissórias e ativos lastreados em hipotecas, empréstimos estudantis, financiamentos de automóveis, etc.

Deste modo, a atuação do FED e do Tesouro foram complementares, ao estabelecer o mercado necessário para absorver todos esses papéis tóxicos e ilíquidos. Mas o governo não se limitou a esse tipo de intervenção, tendo alcançando também instituições em situação de insolvência, como será abordado a seguir. 


\subsection{Assistência direcionada}

Ainda em setembro de 2008, Bernanke comenta que,

"[qualquer tipo de] assistência governamental deve ser fornecida com a maior relutância possível e somente quando a estabilidade do sistema financeiro, e consequentemente, a saúde da economia em geral, está sob risco". ${ }^{42}$

Mas o diagnóstico realizado pelo FED mudou, logo que a escassez de crédito e a aversão generalizada ao risco colocou certas empresas à beira do colapso. Extremamente grandes e interconectadas, a falência dessas estruturas teria capacidade suficiente para desestabilizar a economia nacional, e internacional. Na ausência de um regime apropriado que permitisse a liquidação ou reestruturação dessas empresas, o governo entendeu que não teria escolha senão prover o apoio solicitado.

Government-sponsored enterprises (GSEs), Washington Mutual, Wachovia, AIG, Citigroup, Bank of America (BofA), GM e a Chrysler foram as entidades consideradas sistematicamente importantes, ou muito grandes para falir.

GSEs.

Preferred Stock Purchase Agreements (PSPAs). Programa de garantia a todas as obrigações das GSEs. No início, o Tesouro recebeu USD 1 bilhão de cada GSE em ações preferencias seniores sem voto, com dividendos anuais de 10\% pagos antes de todos os demais acionistas e garantias de 79,9\% de cada empresa, comprometendo-se a prover até USD 200 bilhões para as duas GSEs (sob um programa de empréstimos para assegurar a solvência) e comprar até USD 4 bilhões em MBS emitidos por GSEs. Pouco depois, o limite do programa foi alterado para USD 400 bilhões.

GSE Credit Facility (GSECF). Procurava assegurar a disponibilidade de crédito para GSEs ao prover recursos seguros de acordo com o necessário, conforme condições e prazos estabelecidos pelo secretário do Tesouro. O programa foi encerrado sem efetuar nenhum desembolso.

GSE Mortgage-Backed Securities Purchase Program. Iniciativa para melhorar a disponibilidade de crédito hipotecário e mitigar as pressões sobre as taxas de hipotecas, acordo com as disposições do secretário do Tesouro.

\footnotetext{
42 Fonte: FED Chairman Ben Bernanke Testimony before the Committee on Banking, Housing, and Urban Affairs, U.S. Senate. "U.S. financial markets". September 23, 2008. Tradução nossa.
} 
HOPE for Homeowners (H4H Program). Estabelecido pelo Housing Economic and Recovery Act (HERA), O programa promoveu um sistema nacional para registro a fim de incentivar proprietários de residências a refinanciar seus imóveis em melhores condições.

HFA New Issue Bond Purchase Program (NIBP). O programa buscou prover um mercado suplementar temporário para ativos novos emitidos por Housing Finance Agencies (HFAs). O Tesouro comprou USD 15.3 bilhões em ativos, permitindo a essas entidades manter suas linhas de empréstimo ativas enquanto se adaptavam as mudanças nos mercados.

HFA Temporary Credit and Liquidity Program (TCLP). O Tesouro comprou USD 8.2 bilhões em obrigações de HFAs ligados a empréstimos hipotecários para famílias, a fim de prover uma barreira de liquidez para HFAs locais e estaduais. Com isso, buscava aliviar a pressão sobre as HFAs e permitir que continuassem provendo recursos para as famílias.

Home Affordable Refinancing Program \& Home Affordable Modification Program (HAMP). Parte do Making Home Affordable, o programa incentivou provedores de hipotecas, emprestadores e investidores a modificar os empréstimos daqueles inadimplentes ou na iminência de perder a propriedade, de forma a reduzir o pagamento mensal das prestações das hipotecas a até no máximo 31\% da renda do devedor. Anunciado em fevereiro de 2009 pelo Tesouro, o programa foi financiado a partir de USD 50 bilhões do TARP e USD 25 bilhões do HERA. Em setembro de 2009 já cobria mais de 85\% dos empréstimos imobiliários no país.

Housing Finance Agency Innovation Fund for the Hardest Hit Housing Markets (HFA Hardest Hit Fund ou HHF). Estabelecido em fevereiro de 2010, o programa permitia a HFAs desenharem programas de prevenção a retomada de propriedades em regiões específicas, onde o desemprego é maior e os mercados imobiliários foram mais afetados. O total de USD 7.6 bilhões foi disponibilizado por esse fundo do Tesouro.

Somente as provedoras de financiamento imobiliário contaram com oito programas diferentes para prevenir seu colapso e garantir seu funcionamento.

A partir de setembro de 2008, o FRBNY passou a comprar notas de desconto de agências federais no mercado secundário para o SOMA, que são basicamente obrigações de dívidas de curo-prazo emitidos pela Fannie Mae, Freddie Mac e os Federal Home Loan Banks (FHLBs).

Mas a medida foi insuficiente para dirimir as preocupações com os papéis emitidos por essas entidades. Em 7 de setembro, após consulta com o secretário do Tesouro e o presidente do FED, a Federal Housing Finance Agency (FHFA) anunciou o apoio governamental às GSEs, em condição temporária. 
Essa autoridade foi concedida pelo Housing Economic and Recovery Act (HERA), aprovado em julho de 2008 diante das dificuldades em que já se encontravam as agências responsáveis por grande parte dos contratos de hipoteca no país. ${ }^{43}$

Implicitamente, as GSEs já contavam com a garantia do governo dos Estados Unidos, mas com a intervenção da FHFA, o Tesouro pode desenhar programas específicos para assegurar a liquidez e solvência das agências, a saber: PSPAs, GSECF e o GSE MortgageBacked Securities Purchase Program. Esses instrumentos deveriam atender as necessidades de financiamento das famílias, prevenir perturbações na disponibilidade de financiamento imobiliário e promover a estabilidade dos mercados financeiros envolvidos.

Com a aprovação do EESA e mais tarde do ARRA, o Tesouro pode criar e reformular também ferramentas para apoiar os provedores de hipotecas (HFAs), com recursos do TARP. Entre elas estão: H4H Program, NIBP, TCLP, HAMP e o HFA HHF.

Em Maio, o Congresso assina nova lei, chamada de Helping Families Save Their Homes Act of 2009, impondo medidas para ajudar famílias que enfrentavam a retomada de suas casas. Em síntese, coloca uma série de provisões para encorajar modificações em hipotecas inadimplentes ou na iminência de se tornarem inadimplentes.

Muitas dessas medidas foram implementadas através do H4H Program, e outras, incluíram o aumento de USD 30 bilhões para USD 100 bilhões no montante que o Tesouro pode emprestar ao FDIC, em relação ao seguro de depósitos. O secretário ainda poderia determinar empréstimos de até USD 500 bilhões ao FDIC, após consulta com o presidente, o Board do FED e o FDIC. Além disso, permitia ao FDIC realizar avaliações especiais em instituições depositárias, independentemente de estarem seguradas.

Somente em fevereiro de 2011, o Tesouro apresentou uma estratégia para eliminar progressivamente as GSEs e reformar o sistema de financiamento imobiliário. Pouco

\footnotetext{
${ }^{43} \mathrm{O}$ Housing and Economic Recovery Act of 2008 (HERA) garantiu ao Tesouro, ao FED e a FHFA autoridade para promover a estabilidade dos mercados financeiros e administrar assuntos relacionados a Fannie Mae, Freddie Mac e FHBs, inclusive determinando seu processo de recuperação e/ou liquidação. O HERA também incluiu os seguintes dispositivos: o Tesouro poderia prover suporte financeiro às agências, os programas de seguro de hipotecas da Federal House Administration (FHA) deveriam ser modernizados, criou o programa HOPE for Homeowners (H4H Program), estabeleceu um sistema nacional para registro e licenciamento (S.A.F.E. Act) e a melhora na transparência das transações com os consumidores.
} 
depois, anunciou que começaria a vender seu portfólio de MBS de GSEs em um ritmo gradual, ao invés de aguardar o vencimento desses ativos. Ao mesmo tempo, o FED passa a realizar uma venda competitiva de MBS residenciais (não de GSEs) pelo Maiden Lane II LLC.

Lehman Brothers, Wachovia e Washington Mutual (WaMu). A falência do Lehman Brothers suscitou grande reação do mercado, mas para o FED e o Tesouro, sem um acordo privado não haveria como resolver os problemas de bancos de investimentos. Sob a lei federal, mais especificamente o Anti-Deficiency Act, o Tesouro é proibido de gastar ou emprestar dinheiro, garantir ou comprar ativos sem a aprovação do Congresso. Já o FED, legalmente, pode realizar empréstimos de forma segura, mas não pode fazê-lo quando espera que o empréstimo resulte em perdas de qualquer tamanho. ${ }^{44}$

Por outro lado, nos casos do WaMu e do Wachovia, o Tesouro decidiu agir. No auge da crise financeira, com a retirada de depósitos e o acesso restrito a financiamento, o WaMu entrou em colapso. Por meio da OTS, a agência do Executivo fechou o WaMu e apontou o FDIC como seu controlador, que imediatamente a vendeu para o JPMorgan Chase.

O secretário do Tesouro, em consulta com o Presidente, o FED e o FDIC, autorizou o FDIC a usar seus fundos para facilitar a venda das operações bancárias do Wachovia para a Wells Fargo. Como justificativa, indicou a necessidade de evitar efeitos adversos maiores sobre a economia, ao proteger depositantes, credores e outros clientes do Wachovia.

American International Group, Inc. (AIG) Investment Program. Em setembro de 2008, o FED tomou uma série de ações para responder a necessidade de liquidez e de capital da AIG, com o apoio do Tesouro. Para evitar efeitos adversos e mitigar os riscos sistêmicos de uma falência desordenada da empresa, o Board concedeu um empréstimo de USD 85 bilhões.

Mas, ao ajudar a empresa a cumprir suas obrigações e facilitar a venda de alguns de seus negócios, também impôs custos e fortes restrições aos proprietários, gerentes e credores da empresa. Por exemplo, o governo recebeu direitos de participação que

\footnotetext{
${ }^{44}$ Fonte: PAULSON, “The Economic Collapse”, p. 8, 2010.
} 
corresponderam a 79,9\% da AIG, poder de veto sobre o pagamento de dividendos e substituiu o CEO da empresa.

Em outubro, o FED autorizou um empréstimo adicional de USD 37,8 bilhões, para financiar os títulos mantidos pela AIG. Já no mês seguinte, o programa de crédito foi reestruturado pelo Tesouro, que anunciou a compra de USD 40 bilhões em ações preferenciais da AIG com os recursos do TARP. Em torno de 77,9\% de participação em ações deveria ser emitida para uma SPV, a ser estabelecida pelo AIG tendo o Tesouro como seu beneficiário. Os proventos das ações que fossem liquidadas seriam depositados no General Fund do governo dos Estados Unidos.

O programa passou por nova reestruturação em abril de 2009, tendo o Tesouro trocado USD 40 bilhões em ações preferenciais por USD 41.6 bilhões em participações cumulativas não preferenciais - pagando dividendos de 10\%. Essa modificação resultou numa alteração de custo de USD 172.2 bilhões. Além disso, foi instituído um programa de capital próprio, sob a qual a AIG poderia retirar até USD 29.8 bilhões, caso fosse necessário emitir ações preferenciais adicionais para o departamento.

Já em abril de 2010, o Tesouro aponta dois diretores para o conselho da AIG, como resultado do não pagamento de dividendos.

\section{Citigroup e Bank of America (BofA)}

Capital Purchase Program (CPP). Tinha como intuito fortalecer a base de capital dos bancos, para que pudessem absorver perdas de ativos tóxicos e continuar a emprestar a consumidores e empresas - por meio da compra de ações preferenciais seniores ou debêntures subordinadas. O Tesouro compromete mais de um terço dos fundos do TARP, USD 250 bilhões, mas esse valor cai para USD 208 bilhões em março de 2009, sendo que pelo menos USD 125 bilhões foram investidos em oito grandes instituições.

Asset Guarantee Program (AGP). Foi criado pelo Tesouro em novembro de 2008 com o objetivo de estabilizar o sistema financeiro ao prover garantias contra severas perdas de crédito em instituições financeiras sistemicamente importantes. O programa foi aplicado com extrema discrição pela agência.

Targeted Investment Program (TIP). Ao invés de providenciar assistência caso-a-caso, esse programa, procurava prevenir a perda de confiança em instituições financeira. Estabelecido em dezembro de 2008, permitia a compra ações preferenciais pelo Tesouro.

Com o apoio do FED, o Tesouro anuncia primeiro um plano de compra voluntário de capital de bancos, considerado um investimento que não deveria gerar custos aos 
contribuintes. Para estabilizar o sistema financeiro, seria necessário prover capital a instituições financeiras "viáveis" em todo o país, além de providenciar garantias e acesso a liquidez.

Através do CPP, o Tesouro comprou ações e debêntures do Citigroup. Pouco depois, por meio do AGP, concordou em garantir até USD 5 bilhões em potenciais perdas de um conjunto de empréstimos da empresa no valor de USD 306 bilhões, tendo como contrapartida recebido USD 4 bilhões em participações preferenciais e garantias.

Dessa forma, ficou estabelecido que o Citigroup absorveria os primeiros USD 39.5 bilhões em perdas, o Tesouro uma segunda parte e o FDIC mais USD 10 bilhões em perdas. 0 FED, por sua vez, providenciaria empréstimos para até 90\% do valor remanescente do conjunto de empréstimos, após os pagamentos do Tesouro e do FDIC. A garantia expiraria em 2014 e 2019 para ativos não-residenciais e residenciais, respectivamente.

Por fim, o contrato foi rescindido, o governo não precisou pagar nenhuma perda e manteve USD 5.2 bilhões dos USD 7 bilhões em ativos preferenciais e garantias em ações ordinárias emitidas pelo Citigroup. Dessa forma, o programa foi encerrado com lucro para os contribuintes.

Apesar disso, uma outra assistência excepcional foi desenhada para o Citigroup, ainda em dezembro de 2008. O Tesouro liberou um total de USD 20 bilhões e impôs exigências e restrições maiores que o CPP.

Em junho de 2009, o Tesouro trocou USD 25 bilhões de seu investimento em ações preferenciais seniores do Citigroup por uma nova série (Series M) de ações preferenciais obrigatoriamente conversíveis.

Já em maio de 2011, o programa é novamente modificado, uma vez que o refinanciamento não estava previsto. A alteração permitiu que certas instituições financeiras pudessem trocar seus investimentos de ações do TARP em ações preferenciais pelo Small Business Lending Fund (SBLF).

No caso do BofA, um acordo foi firmado nos mesmos moldes daquele realizado com o Citigroup, após sua fusão com o Merril Lynch, em janeiro de 2009. O Tesouro, o FDIC e o FED concordaram em dividir perdas potenciais de um conjunto de empréstimos do BofA 
no valor USD 118 bilhões. Em maio de 2009, o BofA notificou as demais partes seu desejo de interromper as negociações com relação as garantias contempladas no acordo, pagando USD 425 milhões em taxas as três entidades.

\section{General Motors (GM) e Chrysler.}

Automotive Industry Financing Program (AIFP). Foi instituído em dezembro de 2008 para evitar uma quebra significativa no mercado automotivo norte-americano. Através desse programa, o Tesouro providenciou empréstimos e investimentos de capital, com a exigência de que as empresas desenvolvessem planos para obtenção de viabilidade a longo-prazo.

Auto Supplier Support Program e Warranty Commitment Program. Criados em março de 2009, os dois programas são extensões do AIFP. O primeiro ofereceu a empresas de componentes automotivos qualificadas proteção financeira sobre os recebíveis de fabricantes de automóveis domésticos. O Tesouro disponibilizou USD 5 bilhões para fornecedores da GM e da Chrysler, valor que logo depois foi reduzido para USD 3.5 bilhões. O segundo programa tinha como objetivo promover a confiança dos consumidores, garantindo que as compras de novos carros na GM e Chrysler seriam honradas, destinando USD 640.6 milhões para a GM e a Chrysler recapitalizarem determinados SPVs.

O Tesouro criou um programa específico para ajudar o setor automobilístico. Duas grandes empresas, a General Motors (GM), a Chrysler e suas entidades financiadoras, receberam USD 76 bilhões em empréstimos e investimentos do governo ainda no final de 2008.

No caso da GM, a administração reprovou o seu primeiro plano de reestruturação, colocando como novo prazo final a data de 1 de Junho de 2009. Durante esse período o Tesouro liberou alguns empréstimos adicionais, USD 5.4 bilhões em janeiro e USD 4 bilhões em fevereiro. Após submeter o pedido de falência, o acordo foi revisto, aumentando o limite de empréstimo de USD 13.4 bilhões para USD 15.4 bilhões, e depois para USD 19.4 bilhões.

Em julho de 2009, a nova entidade, NewGM Co. compra os ativos da velha empresa e começa a operar. O Tesouro converte seus empréstimos de USD 2.1 bilhões e 60,8\% das ações para a nova GM. A empresa ainda assume a dívida de USD 7,1 bilhões da velha GM com o Tesouro.

No caso da Chrysler, o Tesouro disponibilizou USD 4 bilhões em janeiro de 2009. Também rejeitou o primeiro plano de reestruturação apresentado pela empresa, determinando a 
necessidade de um parceiro para que recebesse mais dinheiro dos contribuintes. Assim, estabelece uma aliança com a Fiat. Em abril de 2009 submete seu pedido de falência e recebe USD 1.9 bilhões do Tesouro para apoiar a sua reestruturação. Em seguida, seus ativos são vendidos para a nova entidade, New Chrysler, e o Tesouro estabelece nova linha de empréstimo de USD 6.6 bilhões.

Em geral, esse tipo de auxílio gerou muita discussão a respeito do risco moral e da deterioração das contas públicas. A reação do Congresso a esses questionamentos foi fundamentada em três medidas, apresentadas abaixo.

Dodd-Frank Wall Street Reform and Consumer Protection Act of 2010. Considerada a maior reforma de regulação financeira desde a Grande Depressão, a lei foi assinada em julho de 2010, tendo como objetivos centrais: assegurar que os riscos assumidos por instituições financeiras não ameaçassem a saúde da economia como um todo, criando diversos mecanismos para monitorar e mitigar o risco sistêmico, exigir uma reforma básica da supervisão de capital e resolução da autoridade, restaurar a disciplina de mercado, além de proteger os consumidores e investidores de abusos financeiros.

Patient Protection and Affordable Care Act (ACA). Foi a maior revisão de leis fiscais em 20 anos, com mais de 40 provisões sobre impostos e taxas realizada em março de 2010. Foi a mais significativo passo em direção à sustentabilidade fiscal. Essas mudanças acarretaram no aumento de receitas e diminuição da tendência de crescimento dos gastos em saúde, permitindo uma redução do abismo fiscal de longo-prazo. Mais tarde, a Health Care and Education Reconciliation Act of 2010 é aprovada com algumas emendas a essa lei.

Budget Control Act of 2011 (BCA). Em Agosto de 2011, o teto da dívida foi elevado em USD 400 bilhões, para USD 14.7 trilhões e um mês depois, para USD 15.2 trilhões. A Lei também colocou limites aos gastos discricionários (mecanismos de lock-in) entre os anos de 2010 a 2021 e criou um comitê conjunto para a redução do déficit.

Por um lado, ao intervir diretamente na economia e promover o resgate de determinadas empresas em dificuldade, o governo incentiva a tomada de risco em excesso. Como resposta, o Tesouro elaborou uma proposta para promover uma maior regulamentação e fiscalização do sistema bancário e não-bancário.

Aprovado pelo Congresso ainda em 2010, o Dodd-Frank Act produziu diversas mudanças no Tesouro. Para agilizar o sistema regulatório e reduzir a possibilidade de arbitragem, a lei aboliu o Office of Thrift Supervision (OTS), transferindo todos os seus trabalhos para um único escritório, o Office of the Comptroller of the Currency (OCC). 
Além disso, ficou a cargo da agência coordenar e estabelecer os novos escritórios de Consumer Financial Protection Bureau, Council ou o Financial Stability Oversight Council e Federal Insurance Office (FIO). Dessa forma, o Tesouro seria o principal responsável por reunir os esforços de supervisão de atividades relacionadas à proteção de consumidores frente a produtos financeiros, à estabilidade do sistema como um todo, e também, ao setor de seguros. ${ }^{45}$

Por outro lado, os custos para o resgate da economia norte-americana foram imensos. A dívida governamental atingiu 41\% e 53\% do PIB (Produto interno bruto), em 2008 e 2009.

Tabela 2 - A Dívida Bruta Federal do Governo dos Estados Unidos entre 2007-2011.

A Dívida Bruta Federal do Governo dos Estados Unidos entre 2007-2011

\begin{tabular}{rrrrrr} 
Item (bilhões de dólares) & 2007 & 2008 & 2009 & 2010 & 2011 \\
\hline Limite estatutário da dívida & 9.8 & 10.6 & 12.1 & 14.3 & 14.7 \\
& & 11.3 & 12.4 & & 15.2 \\
Total da dívida: (1) & -8.9 & -10.0 & -12.0 & -13.7 & -14.7 \\
Dívida intragovernamental (2) & -3.8 & -4.1 & -4.4 & -4.6 & -4.6 \\
Dívida pública (3) & -5.1 & -5.8 & -7.6 & -9.1 & -10.2 \\
\hline Dívida pública como \% do PIB & $37 \%$ & $41 \%$ & $53 \%$ & $62 \%$ & $68 \%$ \\
\hline
\end{tabular}

Países detentores da dívida pública (bilhões de dólares):

\begin{tabular}{rrrrrr}
\hline China, República Popular da & 467 & 618 & 938 & 1.151 & 1.270 \\
\hline Japão & 591 & 617 & 747 & 860 & 984 \\
\hline Exportadores de Petróleo (4) & 137 & 171 & 201 & 215 & 252 \\
\hline Bancos Centrais do Caribe (5) & 99 & 169 & 116 & 157 & 210 \\
\hline Brazil & 110 & 148 & 153 & 181 & 226 \\
\hline Taiwan & 39 & 63 & 115 & 153 & 166 \\
\hline Rússia & 31 & 99 & 145 & 173 & 149 \\
\hline
\end{tabular}

Notas:

(1) O total da dívida bruta federal é a soma da dívida intragovernamental e da dívida pública. Os empréstimos do governo estão sujeitos a um limite estatutário definido pelo Congresso.

(2) A dívida intragovernamental representa títulos não-comerciáveis emitidos pelo Tesouro em poder de fundos governamentais (por exemplo, fundos de seguridade social e Medicare são obrigados a investir qualquer receita em excesso nos papéis especiais não comerciáveis do governo). Como essas quantias são obrigações do Tesouro e ativos dos fundos de governamentais, elas são eliminadas na consolidação da posição financeira do governo. (3) A dívida pública é composta por títulos do Tesouro, papéis, notas e obrigações que pagam juros em poder de indivíduos, corporações, governos estaduais e locais, Federal Reserve Banks (FRBs), governos estrangeiros e outras entidades. Essa dívida financia as ações do governo e constitui uma obrigação em seu balanço.

Fonte: Os dados correspondem ao valor do fim do ano fiscal (setembro) e foram reunidos pela autora, com base em The Financial Report of the United States Government, entre 2008-2011.

${ }^{45}$ Mais detalhes em U.S. DEPARTMENT OF THE TREASURY, Agency Financial Report FY 2010, pg. 15, 16 \& 17. 
Continuação (Notas Tabela 2):

(4) Exportadores de Petróleo inclui o Equador, Venezuela, Indonésia, Bahrein, Irã, Iraque, Kuwait, Omã, Qatar, Arábia Saudita, Emirados Árabes Unidos, Argélia, Gabão, Líbia e Nigéria.

(5) Bancos Centrais do Caribe compreendem Bahamas, Bermuda, Ilhas Cayman, Antilhas Holandesas e Panamá. Fontes: Os dados correspondem ao valor total de títulos em setembro de cada ano. Tabela elaborada pela autora com base em DEPARTMENT OF THE TREASURY/ FEDERAL RESERVE BOARD. Major Foreign Holders of Treasury Securities. 17 aug. 2015. Disponível em: <http://www.treasury.gov/ticdata/Publish/mfhhis01.txt>. Acesso em: 17 ago. 2015.

Esses foram os maiores números em uma década, e em 50 anos, respectivamente. Durante a maior parte da década anterior, a dívida pública oscilou entre 35\% e 37\% do PIB nacional, aumentando um pouco entre 2002 e 2004 - em função dos gastos em defesa e da queda nas receitas em decorrência de uma breve recessão.

Em termos absolutos, a dívida pública saltou de USD 5.8 trilhões para USD 10.2 trilhões em apenas quatro anos. Equivalente a $37 \%$ do PIB antes da crise, essa dívida alcançou 68\% em 2011. Como a tabela 2 aponta, essa dívida era financiada pela China, em primeiro lugar, e o Japão, em segundo.

Também, a tabela 2 explicita o impacto das inúmeras ações empreendidas pelo governo sobre a dívida bruta federal, composta pela dívida pública e intragovernamental.

Em 2008, o total da dívida girava em torno de USD 10 trilhões, 10.8\% maior que em 2007. Esse montante, vale lembrar, está sujeito a um limite estatutário definido pelo Congresso. Aprovado ainda em 1917, esse teto deveria auxiliar no planejamento durante a Primeira Guerra Mundial, e desde então, foi alterado pelo menos umas 100 vezes.

Em função da turbulência financeira e dos esforços empreendidos para estabilizar os mercados, esse teto passou de USD 10.6 trilhões em outubro de 2008 para USD 14.7 trilhões em agosto de 2011.

Entretanto, autorizar aumentos ao limite da dívida implica em significativos custos políticos. O principal deles se refere ao desequilíbrio fiscal de longo-prazo, causado pelo envelhecimento da população e evolução dos custos de determinadas políticas fiscais.

O Tesouro previa uma aceleração dos gastos com esses programas sociais, enquanto as receitas deveriam seguir um ritmo de crescimento mais lento, principalmente com a situação de fraco desempenho econômico. Consequentemente, o déficit atingiria níveis cada vez maiores em relação ao PIB, o tamanho real da economia. 
Sem mudanças políticas, o impacto seria sentido diretamente sobre a dívida pública e os juros pagos sobre essa dívida. Assim, a capacidade do governo de sustentar o financiamento e pagamento de benefícios da seguridade social, do Medicare e do Medicaid, passou a ser amplamente questionada.

Postergar a implementação de reformas, advertia o Tesouro, também colocaria maior fardo sobre gerações futuras, além de promover maior instabilidade no setor financeiro e aumentar os riscos de incerteza em diversos setores da economia.

Dessa forma, o Congresso precisaria tomar atitudes drásticas para reverter o abismo fiscal. O desafio estava em equilibrar a dívida estrutural e a necessidade em manter os investimentos que davam suporte à recuperação da economia. Mas essa discussão era postergada constantemente.

Por isso, já em dezembro de 2009, o Tesouro delimita quatro elementos para remover as políticas implementadas pelo TARP: encerrar ou reduzir os programas de apoio a instituições financeiras, limitar novos investimentos em imóveis, pequenas empresas e mercados de securitização relacionados, manter a capacidade de responder a ameaças financeiras e, por último, continuar a administrar os investimentos de capital próprio adquiridos.

Um pequeno passo foi dado pelo Congresso em 2010, ao atacar a estrutura dos programas sociais com o ACA. Contudo, esses esforços não foram suficientes. Em relatório sobre a saúde financeira do governo de 2011, o secretário do Tesouro ressaltava que os déficits atuais e projetados do governo eram muito altos, inflados pelos cortes de impostos, decisões de gastos da década anterior, pela crise econômica, envelhecimento da população e aumento dos custos com programas de saúde.

Apesar do alerta e da criação de uma Comissão Presidencial Nacional e Responsabilidade e Reforma Fiscal, a discussão em torno da alteração do teto da dívida em 2011 foi muito lenta, marcada por grandes conflitos políticos e forte repercussão internacional. Em maio 
daquele ano, o departamento foi forçado a se afastar dos procedimentos regulares para gerenciar a dívida. ${ }^{46}$

Ao invocar autoridade legal para evitar exceder o limite de dívida, o Tesouro pode estabelecer as seguintes medidas: suspender investimentos e reinvestimentos (incluindo de juros) de diversos fundos, resgatar recursos mais cedo para realizar pagamento de benefícios e suspender a venda de títulos de governos estaduais e locais. ${ }^{47}$

De acordo com as estimativas do Tesouro, o prazo para realizar novos empréstimos e manter a credibilidade de pagamento do governo dos Estados Unidos se esgotaria em 2 de agosto de 2011. Considerada a dívida mais segura do mundo, a sua nota de risco chegou a ser revisada pela agência Standard\&Poor's durante o impasse no legislativo.

Quase encerrado o prazo final, um compromisso bipartidário foi finalmente alcançado. Num cenário em que o próprio Congresso criou e preveniu um desastre, o secretário do Tesouro afirmou "[que] esse foi um processo terrível, mas trouxe um bom resultado". O acordo evitou a ameaça de calote e taxa de juros mais altas, além de definir metas coerentes para reduzir o déficit governamental, sem afetar a atividade econômica no curto prazo. Apesar disso, o BCA foi considerado um pequeno passo em direção à sustentabilidade fiscal. ${ }^{48}$

De todo modo, o apoio providenciado a instituições bancárias, não-bancárias e o setor automotivo indica, mais uma vez, que as duas entidades desenvolveram medidas e políticas em intensa cooperação.

Além disso, ao socorrerem corporações e segmentos específicos da economia, o FED e o Tesouro determinaram os vencedores e perdedores da crise. Em contrapartida, os contribuintes viram o volume total de dívida pública dobrar um curto intervalo de tempo.

Esse movimento resultou em uma maior pressão sobre a agência responsável pela política fiscal. O banco central, por sua vez, assegurou uma capacidade considerável de

\footnotetext{
${ }^{46}$ President's National Commission on Fiscal Responsability and Reform, ou a Comissão Simpson-Bowles, foi criada por Obama em 2010 para discutir os desafios fiscais do país, reunindo os dois principais partidos para identificar as políticas que poderiam melhorar a situação fiscal no médio prazo e atingir a sustentabilidade fiscal no longo prazo. Fonte: www.fiscalcommission.gov/about

${ }^{47}$ Fonte: U.S. DEPARTMENT OF THE TREASURY, Agency Financial Report FY 2011, p. 117.

${ }^{48}$ Tim Geithner "Compromise Achieved, Reform's the Next Chapter", publicado em 3 de Agosto de 2011 no The Washington Post. Tradução nossa.
} 
exercer sua autoridade monetária através de seu balanço, conforme demonstrado logo abaixo.

\subsection{Gerenciamento do portfólio do FED}

Summary of Economic Projections (SEP). Consiste em previsões baseadas em informações reunidas ao final da reunião do FOMC, com projeções de cada participante para o crescimento econômico, desemprego e inflação para os próximos três anos. O Comitê incluiu o SEP na reunião de 28 \& 29 de outubro de 2008 , mas foi somente após a reunião de 27 \& 28 de janeiro de 2009 ficou estabelecido que o relatório seria publicado a cada trimestre e anexado às atas, com o intuito de prover clareza adicional.

Quantitative Easing 1 (nov-2008 a mar-2010). O FED anuncia iniciativa de comprar até USD 100 bilhões em obrigações diretas de GSEs relacionadas a hipotecas e até USD 500 bilhões em MBS garantidos pelas GSEs. Em março de 2009, o programa é expandido drasticamente, com mais USD 750 bilhões em MBS (elevando o total para USD 1.25 trilhões), mais USD 100 bilhões em dívidas de agências (elevando o total para USD 200 bilhões) e até USD 300 bilhões em títulos do Tesouro de longo-prazo em seis meses. Em agosto e setembro, decidiu-se que o ritmo de compra seria mais lento, para permitir uma transição gradual para os mercados.

Quantitative Easing 2 (nov-2010 a jun-2011). O FED passa a reinvestir o principal dos pagamentos em títulos do Tesouro de longo-prazo e a comprar mais USD 600 bilhões de títulos, USD 75 bilhões por mês até o segundo trimestre de 2011. Logo, esse ritmo é alterado para USD 80 bilhões por mês, para atingir o volume indicado pelo Comitê. Neste caso, foi reforçado que não haveria necessidade de rolar as compras de títulos do Tesouro com o fim do programa, já que esse mercado é mais profundo e líquido.

Reverse repurchase agreements (RRPs). Autorizado em novembro de 2009, o programa de absorção de reservas bancárias envolve títulos do Tesouro e obrigações de qualquer agência dos Estados Unidos como garantias em transações com negociadores primários do FED.

Term Deposit Facility (TDF). Em dezembro de 2009, o FED publica uma nota solicitando comentários sobre a proposta e, aprova em Abril de 2010, mudanças na Regulação D autorizando os FRBs a oferecerem depósitos a prazo a determinadas instituições.

Esta última categoria pretende explicitar a abordagem adotada pelo FED sob a política de taxa de juros zero (zero interest rate policy, ou ZIRP). Diferentemente da política tradicional, de alterar a taxa de juros de curto-prazo da economia, a instituição precisou definir rapidamente novas estratégias para melhorar as condições financeiras quando essa taxa se aproximava do seu mínimo possível. 
Com a implementação de diversos programas adicionais para conter a crise e uma possível recessão, de acordo com o explicitado nos itens acima, o balanço da instituição expandiu de forma muito rápida. Na visão do FOMC, essas medidas representaram a função do banco central como emprestador de última instância, garantindo reservas aos participantes dos mercados.

Em primeiro lugar, o Comitê julgou ser primordial ajudar os mercados a formarem suas expectativas em um ambiente de extrema incerteza. Assim, o Comitê passou a indicar explicitamente as visões dos participantes acerca da trajetória da taxa de juros e da taxa de inflação de longo prazo que melhor promoviam os objetivos do FOMC - de estabilidade de preços e máximo emprego com o desenvolvimento sustentável da atividade econômica.

O SEP promovia um contexto mais delineado para a compreensão das decisões do Comitê, com previsões mais frequentes com um horizonte mais longo e explicações mais detalhadas. Contudo, os formuladores de política monetária também indicaram necessário alterar a linguagem de sua comunicação com o público, a fim de permitir uma melhor orientação que a de costume.

Em seus comunicados, o FOMC passou a recorrer assiduamente a afirmações como: "as condições econômicas devem garantir um nível excepcionalmente baixo para o fed funds por algum tempo", "por um longo período", "por um período extenso".

Já em agosto de 2011, o Comitê delibera que a declaração elaborada logo após a sua reunião deveria fortalecer ainda mais essa orientação, ao explicitar um período específico. Dessa maneira, passou a apontar que o nível excepcionalmente baixo do fed funds duraria pelo menos até a metade de 2013.

Mas o principal programa emergencial criado pela instituição sob essa política foi apelidado de credit easing, mas ficou conhecido como quantitative easing (QE). Essa medida visava facilitar a disponibilidade de crédito e impulsionar o nível de preços para um patamar considerado apropriado pelo Comitê. Além disso, deveria ser calibrada e responsiva à evolução das condições econômicas. 
Divido em duas fases, o primeiro programa de compra de ativos foi implementado devido a indícios de fraco desempenho em diversos setores, com os membros do FOMC assinalando os riscos potenciais de uma recessão longa e difícil.

Posteriormente, com a recuperação global caminhando em duas velocidades distintas (uma para economias avançadas e outra para emergentes), uma segunda política acomodativa foi implementada para que a economia norte-americana pudesse sustentar um crescimento mais robusto e duradouro.

Cabe frisar que o presidente do FED salienta que um programa fiscal seria um importante complemento ao QE2, reconhecendo que existe um limite para o que o banco central pode alcançar sozinho. ${ }^{49}$

Durante a primeira fase, o Comitê apoiou a abordagem provisória do Gerente do SOMA em não reinvestir os proventos de títulos a vencer de agências e pré-pagamentos de MBS. O volume de títulos deveria decair gradualmente com a conclusão do programa de compra de ativos.

Todavia, em Junho de 2010, o Gerente solicitou autorização para realizar transações com coupons de swaps após verificar falhas no mercado de MBS. Com a dificuldade dos negociadores em entregar uma pequena quantidade dos USD 1.25 trilhões de MBS que o FRBNY comprou entre janeiro de 2009 e março de 2010, o Gerente posterga a liquidação dessas transações com a rolagem de dólares. Na prática, o FED rolou as suas compras durante o primeiro trimestre de 2010 para evitar rupturas no mercado de MBS de GSEs. ${ }^{50}$

De forma geral, manter o foco sobre a quantidade e composição de ativos no balanço da instituição implicava em diversos efeitos sobre os próprios ativos, o volume de reservas bancárias e as expectativas de inflação (KOHN, 2010, p.5).

\footnotetext{
${ }^{49}$ Fonte: FED Chairman Ben Bernanke Remarks before the Board of Governors of the Federal Reserve System at the Sixth European Central Banking Conference, in Frankfurt, Germany.. "Rebalancing the Global Recovery". November 19, 2010.

${ }^{50} \mathrm{~A}$ transação de coupons swap é comum no mercado de MBS e envolve duas partes que trocam títulos a preço de mercado. Assim, permitiu ao FED efetivamente vender os títulos escassos que ainda não recebeu e comprar títulos com maior disponibilidade no mercado.
} 
Os papéis de dívida e MBS de agências hipotecárias eram afetados pelas falhas de arbitragem entre os mercados de curto e de longo prazo, falhas que eram exacerbadas pelo pânico, quando investidores exigem prêmios maiores devido à falta de liquidez e segurança desses instrumentos. Com o $Q E$, o banco central retira o risco de juros do mercado, ao pressionar para cima os preços desses ativos e diminuir o seu retorno.

O FED consegue financiar essas compras ao creditar a conta dos bancos nos FRBs. A enorme quantidade de recursos disponível, em teoria, induziria bancos a diversificar linhas de empréstimos e a aquisição de títulos. Como resultado, o custo de financiamentos para famílias e empresas seria reduzido, gerando um aumento na oferta de moeda e nos gastos da economia.

Ao invés disso, as taxas praticadas pelos bancos continuaram elevadas, e a quantidade de empréstimos bancários caia, limitando o crescimento da oferta de moeda. Kohn (2010, p.6) coloca que essa realidade é consistente com o que o modelo keynesiano chama de armadilha de liquidez, quando a demanda de reservas por bancos se torna perfeitamente elástica.

Com a melhora dos indicadores econômicos e da confiança do investidor, o comportamento dos bancos deveria mudar. Esse novo panorama também levaria a outra preocupação, a capacidade do FED em reconfigurar o seu balanço para o tamanho normal. Ou seja, existia o risco de a instituição não conseguir reduzir as reservas e aumentar a taxa de juros no tempo adequado, elevando as expectativas de inflação.

Por essa razão, o FOMC e o Board procuraram desenvolver e aperfeiçoar ferramentas capazes de remover as ações extraordinárias, retirando as reservas a aumentando a taxa de juros, quando apropriado. Um desses instrumentos foi concedido ao FED com o EESA, antes de implementada a ZIRP: a habilidade de pagar juros sobre as reservas obrigatórias e excedentes (IORR e IOER).

Além de duas outras medidas desenhadas para este propósito, o RRP e o TDF, o Comitê delineou uma "exit strategy", estabelecendo princípios para determinar o período e o ritmo de remoção dessa política acomodativa.

O roteiro indicava que o FOMC deveria primeiro encerrar alguns ou todos reinvestimentos de pagamentos do principal na carteira de títulos do SOMA. Ao mesmo 
tempo ou logo depois, deveria modificar a trajetória do fed funds e começar operações de drenagem de reservas (assim que as condições econômicas permitissem). Voltaria assim a usar o nível ou faixa alvo dos juros como a principal ferramenta de política monetária.

Ainda, o Comitê deveria ajustar a taxa de juros sobre as reservas excedentes e o nível de reservas no sistema bancário, para em seguida vender títulos de agências no SOMA, de acordo com um ritmo e período ajustável (gradual e contínuo) comunicado previamente ao público. E por último, esses títulos seriam eliminados da carteira do SOMA, entre 3 e 5 anos.

De qualquer maneira, o FOMC deveria permanecer preparado para ajustar essa estratégia, caso necessário. Essa flexibilidade foi considerada extremamente relevante para os formuladores de política monetária, e pode ser verificada através da tabela 3 apresentada adiante, contendo os principais componentes do balanço do banco central norte-americano.

A evolução dos quatro grupos de ativos presentes nesse balanço, conforme apresentado na Tabela 3, evidencia com maior clareza a capacidade do FED de implementar e retirar diversos novos instrumentos, instituídos para enfrentar a turbulência nos mercados e impulsionar a atividade econômica.

Tabela 3 - Balanço do Federal Reserve System (FED) entre 2007-2011, componentes selecionados. 
Balanço do Federal Reserve System (FED) - componentes selecionados (milhões de dólares)

\begin{tabular}{|c|c|c|c|c|c|c|c|}
\hline Items & $31 / 12 / 07$ & $31 / 12 / 08$ & $15 / 07 / 09$ & $30 / 12 / 09$ & $07 / 07 / 10$ & $29 / 12 / 10$ & $06 / 07 / 11$ \\
\hline Total de ativos & 917.922 & 2.240 .946 & 2.074 .822 & 2.237 .258 & 2.335 .457 & 2.423 .457 & 2.874 .049 \\
\hline \multicolumn{8}{|l|}{ Ativos selecionados } \\
\hline \multicolumn{8}{|l|}{ Crédito a instituições depositárias e negociadores } \\
\hline Crédito primário & 8.620 & 93.769 & 34.743 & 19.111 & 17 & 58 & 5 \\
\hline Crédito TAF & 40.000 & 450.219 & 273.691 & 75.918 & 0 & $\mathrm{n} / \mathrm{a}$ & $\mathrm{n} / \mathrm{a}$ \\
\hline PDCF e crédito outro para corretores & $n / a$ & 37.404 & 0 & 0 & $\mathrm{n} / \mathrm{a}$ & $\mathrm{n} / \mathrm{a}$ & $\mathrm{n} / \mathrm{a}$ \\
\hline Swaps para bancos centrais & 24.000 & 553.728 & 111.641 & 10.272 & 1.245 & 75 & 0 \\
\hline \multicolumn{8}{|l|}{ Crédito a outros participantes do mercado } \\
\hline AMLF & $\mathrm{n} / \mathrm{a}$ & 23.765 & 5.469 & 0 & $\mathrm{n} / \mathrm{a}$ & $\mathrm{n} / \mathrm{a}$ & $\mathrm{n} / \mathrm{a}$ \\
\hline Carteira líquida do CPFF LLC & $\mathrm{n} / \mathrm{a}$ & 334.102 & 111.053 & 14.072 & 1 & $\mathrm{n} / \mathrm{a}$ & $\mathrm{n} / \mathrm{a}$ \\
\hline Carteira líquida do LLCs através do MMIFF & $\mathrm{n} / \mathrm{a}$ & 0 & 0 & $\mathrm{n} / \mathrm{a}$ & $\mathrm{n} / \mathrm{a}$ & $\mathrm{n} / \mathrm{a}$ & $\mathrm{n} / \mathrm{a}$ \\
\hline TALF & $\mathrm{n} / \mathrm{a}$ & $\mathrm{n} / \mathrm{a}$ & 30.121 & 47.532 & 42.278 & 24.704 & 12.488 \\
\hline Carteira líquida do TALF LLC & $\mathrm{n} / \mathrm{a}$ & $n / a$ & $\mathrm{n} / \mathrm{a}$ & $n / a$ & $n / a$ & 665 & 757 \\
\hline \multicolumn{8}{|l|}{ Apoio a insituições críticas } \\
\hline $\begin{array}{l}\text { Carteira líquida do Maiden Lane I, II e III LLC } \\
\text { (1) }\end{array}$ & n/a & 73.925 & 60.546 & 65.024 & 66.996 & 66.312 & 59.637 \\
\hline Crédito estendido ao AIG & $\mathrm{n} / \mathrm{a}$ & 38.914 & 42.871 & 22.033 & 24.560 & 20.282 & $\mathrm{n} / \mathrm{a}$ \\
\hline Juros preferenciais na AIA e ALICO Holding LLC & $\mathrm{n} / \mathrm{a}$ & $\mathrm{n} / \mathrm{a}$ & 30.121 & 25.000 & 25.733 & 26.057 & $\mathrm{n} / \mathrm{a}$ \\
\hline \multicolumn{8}{|l|}{ Títulos em carteira } \\
\hline Títulos do Tesouro & 740.611 & 475.921 & 684.030 & 776.587 & 776.997 & 1.016 .102 & 1.624 .515 \\
\hline Títulos de dívida de agências & 0 & 19.708 & 101.701 & 159.879 & 164.762 & 147.460 & 115.070 \\
\hline MBS de agências (2) & $\mathrm{n} / \mathrm{a}$ & $\mathrm{n} / \mathrm{a}$ & 526.418 & 908.257 & 1.118 .290 & 992.141 & 908.853 \\
\hline \multicolumn{8}{|l|}{ Memo } \\
\hline TSLF (3) & $\mathrm{n} / \mathrm{a}$ & 171.600 & 4.250 & 0 & $\mathrm{n} / \mathrm{a}$ & $\mathrm{n} / \mathrm{a}$ & $\mathrm{n} / \mathrm{a}$ \\
\hline Total de passivos & 881.023 & 2.198 .794 & 2.025 .348 & 2.185 .139 & 2.278 .523 & 2.366 .855 & 2.822 .382 \\
\hline \multicolumn{8}{|l|}{ Passivos selecionados } \\
\hline Notas em circulação & 791.691 & 853.168 & 870.327 & 889.678 & 907.698 & 943.749 & 990.861 \\
\hline RRPs & $\mathrm{n} / \mathrm{a}$ & $\mathrm{n} / \mathrm{a}$ & $\mathrm{n} / \mathrm{a}$ & 70.450 & 62.904 & 59.246 & 67.527 \\
\hline Depósitos de instituições depositárias & 20.767 & 860.000 & 808.824 & 1.205 .271 & 1.061.239 & 1.025 .839 & 1.663 .022 \\
\hline dos quais: TDF & $\mathrm{n} / \mathrm{a}$ & $\mathrm{n} / \mathrm{a}$ & $n / a$ & $n / a$ & 2.122 & 5.113 & 0 \\
\hline Tesouro, conta geral & 16.120 & 106.123 & 65.234 & 149.819 & 16.475 & 88.905 & 67.270 \\
\hline Tesouro, conta de financiamento suplementa & $\mathrm{n} / \mathrm{a}$ & 259.325 & 199.939 & 5.001 & 199.963 & 199.963 & 5.000 \\
\hline Total de capital & 36.899 & 42.152 & 49.474 & 52.119 & 56.934 & 56.602 & 51.667 \\
\hline
\end{tabular}

Notas:

(1) O FED estendeu crédito a diversas LLCs em conjunto aos esforços para apoiar instituiç̃ões críticas. Maiden Lane LLC foi formada para adquirir ativos do The Bear Stearns Companies, Inc. Maiden Lane II LLC foi instituído para comprar ativos lastreados em hipotecadas residenciais (MBS) de subsidiárias da AIG com carteira de títulos norte-americanos para empréstimos de reinvestimento. Maiden Lane III LLC foi instituído para comprar obrigações de dívidas colateralizadas de multisetores em que o grupo de produtos financeiros do AIG tenha realizado contratos de credit default swaps.

(2) Inlcui somente MBS adquiridos que já tenham sido liquidados.

(3) O FED retém a posse de títulos empréstados pelo TSLF.

n/a: não aplicável

Fonte: elaborado pela autora com base em Board's Annual Reports, entre 2008-2011.

O primeiro grupo de ativos, direcionado a negociadores e instituições depositárias sofreu a sua maior expansão no final de 2008, 1.463\% em relação a 2007. Até julho de 2011, todavia, esse movimento foi completamente revertido, restando somente o tradicional programa de Primary Credit - com um nível de crédito de 0,01\% se comparado a seu desempenho no auge da crise.

O segundo grupo de ativos contou basicamente com três programas até o estabelecimento do TALF. Em dezembro de 2008, o CPFF era responsável por 93\% do total de crédito estendido a outros participantes do mercado. Já no fim do ano de 2010, 
os instrumentos desenvolvidos com base no TALF compunham toda a carteira de empréstimos desse grupo.

O terceiro grupo, de apoio a instituições em situação crítica, contou com um grande volume de empréstimos de 2008 até o final de 2010. Em de julho de 2011 ocorre uma forte queda, $47 \%$ em relação ao ano anterior, que refletiu basicamente a venda das ações preferenciais e pagamento de uma parte do crédito concedido a AIG.

No último grupo de ativos, está o portfólio de títulos do FED. Em dezembro de 2008, o nível de títulos do Tesouro caiu 36\% em comparação com 2007, período em que a instituição também passa a comprar títulos de dívida de GSEs. Nos dois semestres de 2009, o volume de títulos do Tesouro aumenta 44\% e 14\%, enquanto o volume de títulos de dívida de GSEs avança 3.087\% e 70\%, respectivamente.

Com a segunda fase de $\mathrm{QE}$, verifica-se novamente uma expansão na quantidade de títulos do Tesouro sob o poder do FED. Já a carteira de títulos de dívida de GSEs começa a ser reduzida lentamente, a partir do fim de 2010.

Por outro lado, as obrigações do balanço de pagamentos do FED são relativamente simples, constituídas pela emissão de papel moeda (Federal Reserve notes) e reservas do sistema bancário depositadas junto ao Federal Reserve System. ${ }^{51}$

As novidades surgem em 2008, com o programa de financiamento suplementar do Tesouro e, em 2009, com as duas novas ferramentas empregadas para auxiliar na retirada da política acomodativa (RRPs e TDF).

Sob a conta da supplementary financing account, percebe-se dois grandes movimentos, um no sentido de proporcionar ao Tesouro maior flexibilidade no gerenciamento da dívida (em dezembro de 2009 e em julho de 2011), com a dívida se aproximando do limite; e outro em 2010, após a elevação do teto da dívida. ${ }^{52}$

Em síntese, o balanço do banco central norte-americano expandiu 313\% no período. No segundo semestre de 2008, esse crescimento foi bastante concentrado no grupo de

\footnotetext{
${ }^{51}$ Fonte: FED Chairman Ben Bernanke at the National Press Club, Washington D.C. "Federal Reserve Policies to Ease Credit and Their Implications for the Fed's Balance Sheet". February 18, 2009.

52 Fonte: FEDERAL RESERVE BOARD, Board's Annual Report 2009, p.32 e Board's Annual Report 2010, p.61.
} 
empréstimos para instituições depositárias e negociadores, representando 51\% do total de ativos. No entanto, os títulos do tesouro e de GSEs representam $62 \%$ do total de ativos já em julho de 2009, chegando dois anos mais tarde a responder por 92\%.

Em geral, o gerenciamento do portfólio do FED demonstra um trabalho em intensa cooperação com o Tesouro. Segundo Bernanke, “[...] tal colaboração não é incomum. Nós temos, tradicionalmente, trabalhado muito próximo a outras agências na promoção de condições financeiras estáveis, [...]". ${ }^{53}$

De fato, o banco central abandona a estratégia relacionada à taxa de juros, e passa a transmitir as suas decisões em política econômica através de seu balanço. Essa abordagem não é convencional, e como exemplificado acima, criou um montante enorme de reservas bancárias. Muito próximo a medidas fiscais, os programas desenvolvidos pelo FED também facilitaram o gerenciamento da dívida do governo, ao reduzir as taxas de juros cobradas por títulos Tesouro de longo-prazo.

\section{Convergência das políticas anti-crise}

Com a intensificação da crise financeira global, a partir de setembro de 2008, o banco central norte-americano e o Tesouro adotaram uma postura mais agressiva que a tradicional, propondo e implementando medidas bem mais intervencionistas do que habitualmente faziam nas décadas anteriores.

Após a falência do banco de investimentos Lehman Brothers, especialmente, as ações dessas duas instituições convergiram no sentido de prover financiamento, liquidez e garantias aos mercados e empresas considerados essenciais para o funcionamento de todo o sistema financeiro. As quatro categorias abordadas neste trabalho demonstram esse esforço.

Dentre elas, somente a estratégia de prover empréstimos de curto-prazo a instituições financeiras faz parte do rol de atividades desempenhadas por um banco central em

\footnotetext{
53 Fonte: FED Chairman Ben Bernanke at the Federal Reserve Bank of Richmond 2009 Credit Markets Symposium, Charlotte, North Carolina "The Federal Reserve's Balance Sheet". April 3, 2009.
} 
situações de estresse financeiro. Já as demais intervenções, provisão de liquidez a mercados específicos, assistência direcionada e o gerenciamento de portfólio não seguiram qualquer padrão ou regra pré-estabelecida.

Foram inovações elaboradas pelas autoridades em função de um dispositivo no Federal Reserve Act, permitindo ao FED realizar empréstimos em circunstâncias extraordinárias. Essas respostas, todavia, foram consideradas arbitrárias e não convencionais por White (2010, p. 455), que cita três exemplos simbólicos: a criação de mecanismos de liquidez para instituições não-bancárias e para a compra de ativos tóxicos, o estabelecimento de uma SPV para facilitar o investimento na AIG e, a interferência no acordo de fusão entre o Merrill Lynch e o Bank of America.

Cabe lembrar que a maior parte dessas decisões foi tomada antes pelo Board, e não pelo comitê responsável por conduzir a política monetária. Dentro do FOMC, essas ações nem sempre contaram com a aprovação unânime, principalmente a partir de 2010, quando pelo menos um membro se posicionou contra a manutenção ou a retomada de medidas expansionistas.

Nesse sentido, o FOMC buscou dar mais clareza as suas atitudes, com o intuito de ancorar as expectativas dos investidores e reafirmar a sua independência. Utilizando a sua flexibilidade com prudência, a instituição acreditava ser possível implementar e retirar políticas acomodativas adicionais sem perder a sua credibilidade ou independência.

A política organizada pelo Tesouro não foi muito distinta, ao injetar capital em bancos e empresas. Inicialmente, a agência promoveu uma enorme extensão de garantias, uma vez que dependia de uma clara disposição do Congresso para utilizar recursos públicos no resgaste ao sistema financeiro. Por isso, aludindo a um ambiente de completo caos, tanto o FED como o Tesouro advogaram intensamente por uma resposta política, rápida e forte.

Depois de confirmados os dois planos fiscais emergenciais, o FED e o Tesouro, então, assumiram riscos de liquidez, de crédito e de juros a fim de evitar uma depressão, enfrentar a recessão e reestabelecer a confiança dos investidores. A estratégia de ambas as entidades incluiu o estabelecimento de linhas de financiamento, a expansão de 
garantias e a disponibilização de acesso a capital para instituições financeiras em geral, mediante a apresentação de diversos tipos de garantias.

Com o tempo, e estando o pânico financeiro cada vez mais distante da realidade dos cidadãos e da classe política, as decisões do secretário do Tesouro passaram a ser criticadas, em um grau muito superior se comparado ao banco central. Depois de implementados os gigantescos pacotes de estímulos à economia, a maior parte dos esforços da agência se concentrou em justificar as suas ações e promover reformas para garantir a adoção de um regime regulatório financeiro adequado.

O custo político abrangeu o risco moral de socorrer bancos e a contínua deterioração das contas do governo, com o aumento significativo do déficit orçamentário e da dívida pública. Apesar de fundamental, a discussão em torno do problema da sustentabilidade fiscal foi constantemente postergada pelo Congresso até que a situação atingiu um contexto dramático em 2011.

É difícil estabelecer uma conexão direta com a questão da posição internacional do dólar, no entanto, verificou-se que a dívida pública dos Estados Unidos neste período não representou um entrave para a confecção das inúmeras medidas. Contraditoriamente, a grande necessidade de financiamento do governo encontrou uma crescente demanda por ativos de qualidade e baixo risco. O papel do dólar nos diversos mercados internacionais foi reforçado, colaborando para a queda nos déficits orçamentário e em transações correntes, ajudando na recuperação da economia norte-americana.

Na maior parte do tempo, portanto, a convergência entre a política monetária e fiscal tratou de reafirmar a capacidade de reação do governo. Sem essa articulação, muitos dos programas implementados pelas autoridades não seriam viáveis, diante da ausência de um consenso político.

Como resultado, a "exit strategy" nunca foi completamente adotada, e ainda em 2015, o FED pratica uma abordagem discricionária para conduzir a política monetária. E na medida em que as atividades do Tesouro estão sujeitas a uma supervisão mais próxima do Congresso, a capacidade do banco central em criar trilhões de dólares continua sendo uma alternativa nada desprezível. 


\section{Considerações finais}

Diante da percepção de agravamento da crise financeira global, o banco central norteamericano e o Tesouro desenvolveram uma série de práticas inovadoras. Em conjunto, as respostas não convencionais foram sendo testadas e conduzidas com foco acentuado em superar a recessão e permitir a recuperação e sustentabilidade da atividade econômica.

A flexibilidade das políticas adotadas permitiu a adequação dessas ações conforme a crise foi evoluindo. Essa capacidade foi maximizada com o aval do Congresso para a utilização de bilhões de dólares de contribuintes, redistribuindo para toda a sociedade norteamericana os prejuízos que, de outra forma, seriam absorvidos pelos mercados, investidores e credores.

Mas ao analisar as ações dessas entidades em conjunto, o trabalho apontou que as autoridades foram obrigadas a repetidamente repensar as estratégias adotadas e desenvolver mecanismos cada vez mais elaborados.

Basicamente, essas medidas emergenciais procuraram atender as necessidades de financiamento de curto-prazo de participantes bancários e não-bancários, criar instrumentos para absorver ativos tóxicos e ilíquidos, apoiar grandes corporações em situação crítica, e exercer política econômica através do balanço do banco central.

Partindo dessa categorização, o trabalho buscou identificar e examinar a estratégia defendida por cada uma dessas instituições, como também a forma pela qual elas interagiram. As políticas de crédito adotadas pelo FED, em especial, demonstraram a habilidade da entidade em converter o volume extraordinário de reservas bancárias em operações que seriam normalmente conduzidas pelos mercados.

A dívida orçamentária e a dívida pública, por outro lado, não constituíram limitações para a atuação dessas duas autoridades. Durante o período entre 2008-2011, a busca por segurança fortaleceu a demanda por títulos do Tesouro dos Estados Unidos, reduziu ainda mais as taxas pagas pelo governo para se financiar e, consequentemente, minimizou o impacto fiscal das medidas expansionistas empregadas. 
O custo político foi considerável, todavia, os compromissos alcançados pelo Congresso incluíram uma reforma do sistema regulatório financeiro nacional e o desenvolvimento de alguns poucos mecanismos para tentar reverter o abismo fiscal.

A articulação entre o Federal Reserve e o Departamento do Tesouro consagrou uma nova maneira de conduzir a política econômica, visando essencialmente superar condições negativas de curto-prazo na economia.

\section{Referências ${ }^{54}$}

ALESINA, A. Fiscal Policy after the Great Recession. Apresentado na 73 Conferência Internacional Econômica do Atlântico em 30 mar. 2012 em Istanbul, Turquia. Atl Econ J (2012) 40:429-435.

BERNANKE, B. The Global Saving Glut and the U.S. Current Account Deficit. Federal Reserve Board. May 2005.

BLANCHARD, O. Macroeconomia. São Paulo: Pearson. Prentice Hall, 2011.

BLINDER, A. Bancos centrais: teoria e prática. São Paulo: Editora 34, 1999.

BOARD OF GOVERNORS OF THE FEDERAL RESERVE SYSTEM, Washington, USA. The Federal Reserve System: Purpose \& Functions, $9^{\text {th }}$.ed. Washington (DC): Federal Reserve, June 2005. Disponível em: <http://www.federalreserve.gov/pf/pf.htm>. Acesso em: 15 out. 2014.

95 ${ }^{\text {th }}$ Annual Report, Washington (DC): Federal Reserve, 2008. Disponível em: < http://www.federalreserve.gov/publications/annual-report/>. Acesso em: 15 out. 2014.

96 ${ }^{\text {th }}$ Annual Report, Washington (DC): Federal Reserve, 2009. Disponível em: < http://www.federalreserve.gov/publications/annual-report/>. Acesso em: 15 out. 2014. 97 ${ }^{\text {th }}$ Annual Report, Washington (DC): Federal Reserve, 2010. Disponível em: < http://www.federalreserve.gov/publications/annual-report/>. Acesso em: 15 out. 2014.

\footnotetext{
54 De acordo com a Associação Brasileira de Normas Técnicas. NB 6023.
} 
98 $8^{\text {th }}$ Annual Report, Washington (DC): Federal Reserve, 2011. Disponível em: < http://www.federalreserve.gov/publications/annual-report/>. Acesso em: 15 out. 2014.

Minutes of the Federal Open Market Committee, Washington (DC): Federal Reserve, 2008. Disponível em: < http://www.federalreserve.gov/monetarypolicy/fomc_historical.htm>. Acesso em: 15 out. 2014.

Minutes of the Federal Open Market Committee, Washington (DC): Federal Reserve, 2009. Disponível em: < http://www.federalreserve.gov/monetarypolicy/fomc_historical.htm>. Acesso em: 15 out. 2014.

. Minutes of the Federal Open Market Committee, 2010. Disponível em: < http://www.federalreserve.gov/monetarypolicy/fomccalendars.htm>. Acesso em: 15 out. 2014.

. Minutes of the Federal Open Market Committee, 2011. Disponível em: < http://www.federalreserve.gov/monetarypolicy/fomccalendars.htm>. Acesso em: 15 out. 2014.

Monetary Policy Report to the Congress: Submitted pursuant to section 2B of the Federal Reserve Act. Washington (DC): Federal Reserve, 2008. Disponível em: < http://www.federalreserve.gov/monetarypolicy/mpr_default.htm>. Acesso em: 15 out. 2014.

Monetary Policy Report to the Congress: Submitted pursuant to section 2B of the Federal Reserve Act. Washington (DC): Federal Reserve, 2009. Disponível em: < http://www.federalreserve.gov/monetarypolicy/mpr_default.htm>. Acesso em: 15 out. 2014.

Monetary Policy Report to the Congress: Submitted pursuant to section 2B of the Federal Reserve Act. Washington (DC): Federal Reserve, 2010. Disponível em: < http://www.federalreserve.gov/monetarypolicy/mpr_default.htm>. Acesso em: 15 out. 2014. 
Monetary Policy Report to the Congress: Submitted pursuant to section 2B of the Federal Reserve Act. Washington (DC): Federal Reserve, 2011. Disponível em: < http://www.federalreserve.gov/monetarypolicy/mpr_default.htm>. Acesso em: 15 out. 2014.

BORDO, M. D. The Federal Reserve: Independence Gained, Independence Lost. Shadow Open Market Committee, 2010.

BRAGA, J. C. Crise Sistêmica da financeirização e a incerteza das mudanças. Estudos Avançados 23 (65), 2009, 89-102.

BULLIO, et al. A atuação do FED antes e depois do estouro da bolha imobiliária, Economia e Sociedade, Campinas, v.20, n.2 (42), Ago. 2011, p.329-364.

BUSH, G. W. President Bush's Speech to the Nation on the Economic Crisis. New York Times, 24 sep. 2008.2 Disponível em: <http://www.nytimes.com/2008/09/24/business/economy/24textbush.html?pagewanted=all\&_r=0>. Acesso em: 01 jul. 2015.

CALOMIRIS, C. W. Restoring Monetary Policy Independence: The risks of regulatory reform. Shadow Open Market Committee, 2010.

CECCHETTI, S. G. The Federal Reserve in the Early Stages of the Financial Crisis. Journal of Economic Perspectives, Vol. 23, N.1 (Winter 2009), p.51-76.

CUKIERMAN, A. The Roles of Ideology, Institutions, Politics, and Economic Knowledge in Forecasting Macroeconomic Developments: Lessons from the Crisis. CESifo Economic Studies, Vol. 56, 4/2010, p.575-595.

DE CECCO, M. Global Imbalances: Past, Present, and Future. Contributions to Political Economy, 2012 (31), p. 29-50.

DURAN, Camila V. A moldura jurídica da política monetária: um estudo de caso. 2012. 288 f. Tese (Doutorado), Universidade de São Paulo, São Paulo, 2012.

EICHENGREEN, B. Privilégio exorbitante: a ascensão e a queda do dólar e o futuro do Sistema monetário internacional. Rio de Janeiro: Elsevier, 2011. 
FEDERAL RESERVE HISTORY. People. Disponível em: <http://www.federalreservehistory.org/People/GraphicalView/15>. Acesso em: 01 jun. 2015.

FEDERAL RESERVE BOARD CHAIRMAN BEN BERNANKE. The FED and the Financial Crisis. College Lecture Series. March 20, 22, 27 and 29, 2012.

Interview with 60 minutes. Dec 5, 2010. Disponível em: $<w w w . c b s n e w s . c o m / v i d e o s / f e d-c h a i r m a n-b e r n a n k e-o n-t h e-e c o n o m y />$. Acesso em: 01 jun. 2015.

FEDERAL RESERVE BOARD VICE CHAIRMAN DONALD L. KOHN. The Federal Reserve's policy actions during financial crisis and lessons for the future. May 13, 2010.

GILPIN, R. Global political economy: understanding the international economic order, New Jersey: Princeton University Press, 2001.

GOODFRIEND, M. Clarifying Central Bank Responsibilities for Monetary Policy, Credit Policy and Financial Stability. Carnegie Mellon University and National Bureau of Economic Research. Mar 2010.

The Elusive Promise of Independent Central Banking. Carnegie Mellon University and National Bureau of Economic Research. May 2012.

GOWAN, P. Crise no centro. Consequências do Novo Sistema de Wall Street. Estudos Avançados 23 (65) 2009, p.49-72. Disponível em: < http://www.scielo.br/scielo.php?script=sci_arttext\&pid=S0103-40142009000100004> Acesso em: 03 fev. 2015.

HAUSMANN, R.; VELASCO, A. The causes of financial crises: moral failure versus market failure, 2004. Kennedy School of Government, Harvard University.

HELLEINER, E. A Bretton Woods moment? The 2007-2008 crisis and the future of global finance. International Affairs, 86:3, 2010, p.619-636.

MENDONÇA, F; et al. A Dívida pública norte-americana em perspectiva histórica: razões e consequências. In: III Simpósio de Pós-Graduação em Relações Internacionais do 
Programa "San Tiago Dantas" (UNESP, UNICAMP e PUC/SP), 2011, São Paulo. Simpósio de Pós-Graduação em Relações Internacionais do Programa San Thiago Dantas, 2011.

MELTZER, A. H. Politics and the Fed. Journal of Monetary Economics 58 (2011), 39-48. Learning about Policy from the Federal Reserve History. Cato Journal, Vol.30, N.2 (Spring/Summer 2010), 279-309.

ROUBINI, N.; MIHN, S. A economia das crises: um curso relâmpago sobre o futuro do sistema financeiro internacional. Rio de Janeiro: Intrínseca, 2010.

TAYLOR, J. B. The Financial Crisis and the Policy Responses: an empirical analysis of what went wrong. Working Paper 14631 from the National Bureau of Economic Research. Jan 2009.

THOMAS, L. B. The Financial Crisis and Federal Reserve Policy. Palgrave Macmillan, 2011.

U.S. DEPARTMENT OF THE TREASURY. U.S. Department of the Treasury. Disponivel em: <http://www.treasury.gov/about/role-of-treasury/Pages/default.aspx>. Acesso em: jun .2015 .

- Strategic Plan FY 2007-2012. Disponível em: $<$ http://www.treasury.gov/about/budget-performance/strategicplan/Pages/index.aspx>. Acesso em: 01 jun. 2015.

Agency Financial Report FY 2011. Disponível em: < Acesso em: 01 jun. 2015.

A citizen's guide to the 2008 Report of the United States Government: The Federal Government's Financial Health. Washington, D.C., 2008. Disponível em: < http://www.gao.gov/financial_pdfs/citizensguide2008.pdf>. Acesso em: 05 jul. 2015.

A citizen's guide to the 2009 Report of the United States Government: The Federal Government's Financial Health. Washington, D.C., 2009. Disponível em: < http://www.gao.gov/financial_pdfs/fy2009/09guide.pdf>. Acesso em: 05 jul. 2015.

"A citizen's guide to the 2010 Report of the United States Government: The Federal Government's Financial Health. Washington, D.C., 2010.Disponível em: < http://www.gao.gov/financial_pdfs/fy2010/10guide.pdf>. Acesso em: 05 jul. 2015. 
A citizen's guide to the 2011 Report of the United States Government: The Federal Government's Financial Health. Washington, D.C., 2011. Disponível em: <http://www.gao.gov/financial_pdfs/fy2011/11guide.pdf>. Acesso em: 05 jul. 2015.

. Budget in Brief 2008, 2009, 2010 e 2011. Disponível em: $<$ http://www.treasury.gov/about/budget-performance/annual-performanceplan/Pages/default.aspx>. Acesso em: 01 jun. 2015.

Performance \& Accountability Report FY 2008, 2009 e 2010. Disponível em: < Acesso em: jun. 2015.

Press Center. Disponível em: <http://www.treasury.gov/presscenter/Pages/default.aspx>. Acesso em: 01 jun. 2015.

U.S. DEPARTMENT OF THE TREASURY, SECRETARY OF THE TREASURY HENRY M. PAULSON JR. The Economic Collapse. Speech at the Ronald Reagan Presidential Library, November 20, 2008.

WESSEL, D. In Fed, We trust: Ben Bernanke's war on the Great Panic. Crown Business: New York. (Kindle Edition).

WHITE, L. The Rule of Law or the Rule of Central bankers? Cato Journal, vol. 30, n3 (Fall 2010). Cato Institute.

WOLF, M. Uma ferramenta não tradicional. Jornal Valor Econômico, [São Paulo] 07 Out 2014. Original: Financial Times, [London] 05 Oct 2014.

WOOLEY, J. T. Monetary Politics: The Federal Reserve and the Politics of Monetary Policy. Cambridge, 1984.

WYPLOSZ, C. International Financial Instability. Global Public Goods: International Cooperation in the 21st century. New York: Oxford University Press, 1999, p.152-189. 


\section{APÊNDICE A - Principais ações e decisões do Federal Reserve System (FED) e do Departamento do Tesouro}

Para desenvolver o presente estudo, foram selecionados os seguintes documentos compreendendo o período entre setembro de 2008 e agosto de 2011:

(i) Board's Annual Report;

(ii) Monetary Policy Report;

(iii) Atas das reuniões do FOMC;

(iv) Plano Estratégico para o período fiscal entre 2007-2012;

(v) Agency Financial Report (AFR);

(vi) Budget- in-Brief (BIB);

(vii) The Financial Report of the United States Government Report;

(viii) Statements, Joint Statements, Testimonies, Remarks e Op-Ed (204): comunicados, depoimentos ou artigos elaborados pelo presidente do FED (66) e o secretário do Tesouro (138).

Após exame desses documentos, foi possível identificar as principais medidas implementadas pela autoridade monetária e pela autoridade fiscal, relacionadas a seguir, nos Quadros A-1 e A-2.

\section{Setembro de 2008}

Anuncia que o Desk do FRBNY conduzirá operações no mercado aberto para tentar manter o fed funds próximo ao alvo, 2\%;

Amplia as garantias aceitas pelo TSLF para incluir todos os títulos de dívida com grau de investimento;

Amplia as garantias aceitas pelo PDCF para incluir tipos de garantias que podem ser requisitadas por tri-party funding arrangements de grandes bancos;

Resolução altera o parágrafo 1.A da Autorização para Operações com moedas estrangeiras para incluir o dólar australiano na lista de moedas que o FRBNY pode transacionar no sistema de mercado aberto; 
Anuncia o AMLF, estende os empréstimos a taxas de crédito primário para instituições depositárias e companhias bancárias para financiar a compra de papéis comercias lastreados por ativos de alta qualidade de fundos mútuos no mercado monetário; Tesouro anuncia Supplememtary Financing Program (SFP), a pedido do FED; Estende e amplia os acordos de swap com BCs estrangeiros até 30 de Abril de 2009; Autoriza extensão de crédito a subsidiárias no Reino Unido do Goldman Sachs, Morgan Stanley e Merril Lynch, como também a seus negociadores primários; Aprova, com o apoio do Tesouro, empréstimo de USD 85 bilhões para a AIG.

\section{Outubro de 20008}

Reduz ofed funds de 2,0\% para 1,5\% em ação coordenada com outros BCs, e depois para $1 \%$;

Elimina o limite quantitativo formal para swap arrangements com BCs estrangeiros;

Cria o CPFF e o MMIFF;

Comunica, em conjunto com o Tesouro e o FDIC detalhes sobre o CPFF, o plano de compra voluntária de capital do Tesouro (CPP) e que FDIC passa a garantir temporariamente todos as dívidas sênior não-seguradas de instituições e companhias associadas ao FDIC, como também, os saldos em contas que não recebem juros;

Autoriza mais USD 37,8 bilhões para financiar títulos com grau de investimento emprestados a subsidiárias da AIG, reguladas no país, através da Maiden Lane II LLC;

Eleva para USD 900 bilhões o crédito disponível para o programa TAF;

Passa a publicar o Summary of Economic Projections (SEP).

Novembro de 2008

Estende o PDCF e o AMLF até 30 de Abril de 2009;

Estende autorização do TSLF até 30 de Outubro de 2009;

Aprova créito ao Citigroup, a fim de prover uma barreira de liquidez em um consórcio de USD 306 bilhões, parte de pacote coordenado com o Tesouro e o FDIC;

Autoriza extensão de crédito a subsidiária londrina do Citigroup; Aprova reestruturação do suporte a AIG: reduz o empréstimo inicial para USD 60 bilhões, recebe os pagamentos e encerra a Maiden Lane II LLC, e concede USD 35 bilhões através da Maiden Lane III LLC; 


\begin{tabular}{|c|}
\hline $\begin{array}{l}\text { Anuncia iniciativa para a compra de até USD } 100 \text { bilhões em obrigações diretas de GSEs } \\
\text { relacionadas a hipotecas, e até USD } 500 \text { bilhões em MBS garantidos por GSEs; }\end{array}$ \\
\hline $\begin{array}{l}\text { Cria o TALF. O FED seria responsável por emprestar USD } 200 \text { bilhões e o Tesouro } \\
\text { disponibiliza USD } 20 \text { bilhões, e proteção de crédito. }\end{array}$ \\
\hline Dezembro 2008 - Janeiro 2009 \\
\hline $\begin{array}{l}\text { Através do EESA, aprova política para ajudar a prevenir e evitar o encerramento de } \\
\text { ativos de hipotecas residenciais, que estão sujeitos a seção } 110 \text { e estão em poder ou } \\
\text { são controlados por um FRB e/ou uma liability company do FED; }\end{array}$ \\
\hline Reduz o fed funds para margem entre $0 \%$ a 0,25\%; \\
\hline Aprova acordo com o Bank of America, com apoio do Tesouro e do FDIC; \\
\hline Aprova revisões de prazo e condições do TALF; \\
\hline $\begin{array}{l}\text { Foco em outras ferramentas: comunicação com o público e como melhor uso do } \\
\text { balanço do FED; }\end{array}$ \\
\hline Prorroga as autorizações do PDCF, AMLF, CPFF e o MMIFF para 30 de Outubro de 2009; \\
\hline Estende o programa TSLF para 30 de Outubro de 2009; \\
\hline Decide coletar e publicar o SEP a cada trimestre; \\
\hline Aprova alteração na taxa de juros usada no CPFF; \\
\hline Aprova mudanças ao MMIFF, incluindo alguns parametros e invetidores elegíveis; \\
\hline Altera a taxa de juros do TAF, passando a ser a mesma paga pelo FED sob o IOER. \\
\hline Fevereiro 2009 - Março 2009 \\
\hline Anuncia revisões nos prazos e condições do TALF; \\
\hline Anuncia o Financial Stability Plan (FSP), em conjunto com o FDIC e o Tesouro; \\
\hline $\begin{array}{l}\text { Aprova reestruturação da assistência ao AIG (FRBNY provê USD 8,5 bilhões a SPV de } \\
\text { subsidiárias), e novo capital à empresa através do Tesouro; }\end{array}$ \\
\hline $\begin{array}{l}\text { Resolução: incrementa a rede de bancos centrais autorizados a utilizar linhas de swap, } \\
\text { aumentando os limites existentes e estendendo os acordos até } 30 \text { Outubro de 2009; }\end{array}$ \\
\hline $\begin{array}{l}\text { Autoriza compra de mais USD } 750 \text { bilhões em MBS, elevando o total para USD } 1.25 \\
\text { trilhões para o ano de 2009, e de USD } 100 \text { bilhões para USD } 200 \text { bilhões em dívidas de } \\
\text { GSEs e até USD } 300 \text { bilhões em títulos do Tesouro de longo-prazo nos próximos seis } \\
\text { meses; }\end{array}$ \\
\hline Anunc \\
\hline
\end{tabular}


Expande a quantidade de instrumentos financeiros permitidos no programa TALF, para incluir outros tipos de ABS.

\section{Abril 2009 - Outubro 2009}

Estende acordos de swap com BCs do Canadá e México, por estarem associados ao NAFTA;

Estabelece duas novas taxas de juros para certos empréstimos pré-fixados de ABS, sob OTALF;

Aprova a expansão da lista de garantias exigidas pelo TALF para empréstimos de CMBS; Autoriza empréstimos do TALF com prazos de 5 anos para financias compras de novos CMBS e ABS;

Aprova uma taxa alternativa para garantias de ABS, sob o TALF e esclarece outras mudanças técnicas ao prazo e condições do programa;

Aprova aumento a taxa administrativa para o TALF;

Aprova ajustes aos limites aplicados a todos os empréstimos sob o TALF para o PPIF do Tesouro;

Publica o SCAP, em conjunto com o Tesouro e o FDIC;

Autoriza uma modificação técnica ao programa de empréstimos de títulos overnight, para incluir obrigações diretas de agências federais;

Estende os programas TSLF, AMLF, CPFF e PDCF até 1 de Fevreiro de 2010;

Reduz o montante do TAF, de USD 150 bilhões para USD 125 bilhões a partir de 13 de Julho de 2009, e USD 100 e USD 75 bilhões a partir de Agosto e Setembro respectivamente;

Suspende, reduz a frequência e o tamanho de alguns leilões do TSLF para USD 75 bilhões;

Comunicado antecipa que o fed funds deveria permanecer "excepcionalmente baixa por um período prolongado";

Coloca a necessidade de refinar a estratégia do Comitê para uma eventual retirada da política de acomodação;

Decide que o ritmo de compra de títulos do Tesouro seria mais lento e concluído até o final de Outubro, permitindo uma transição gradual; 


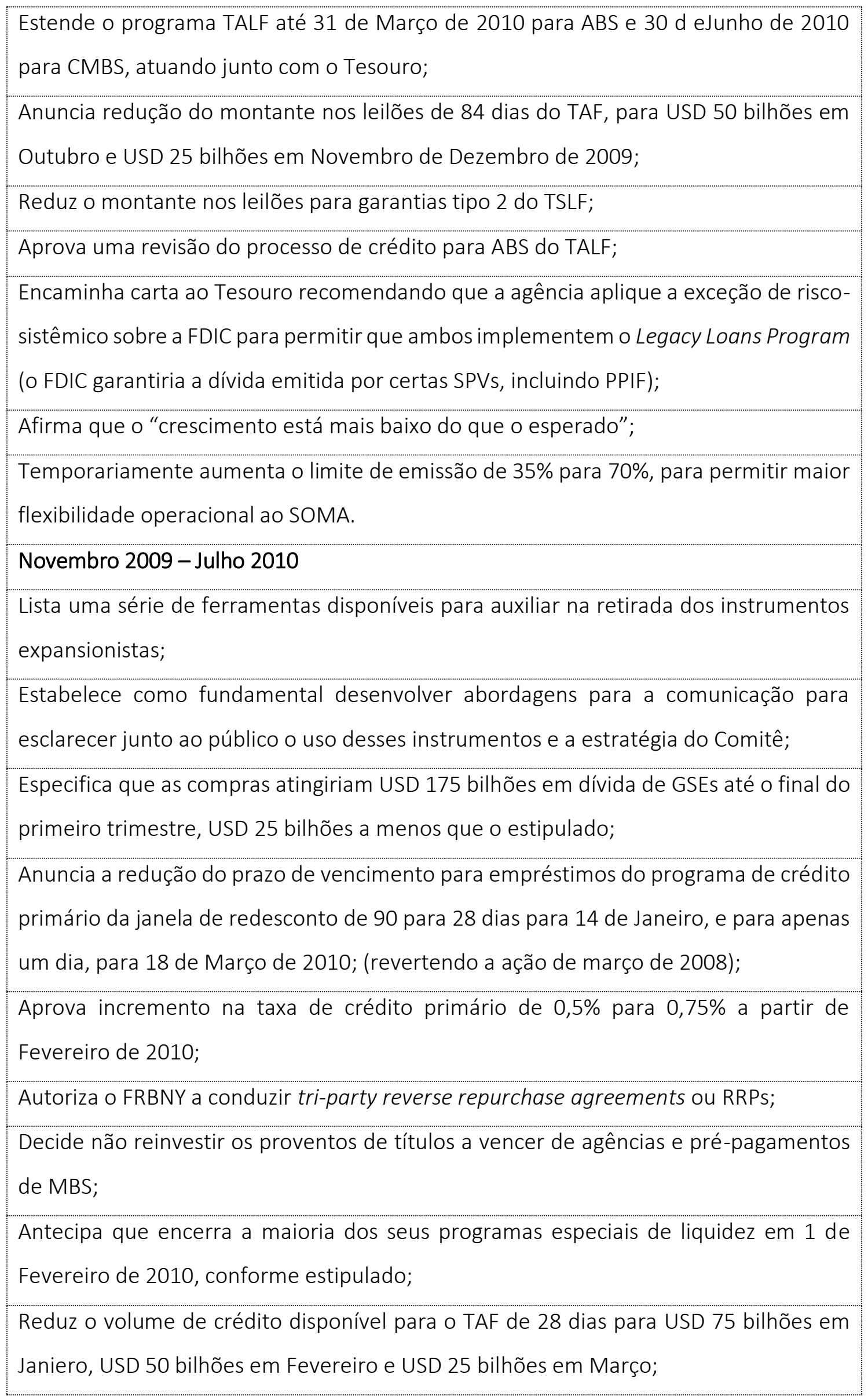




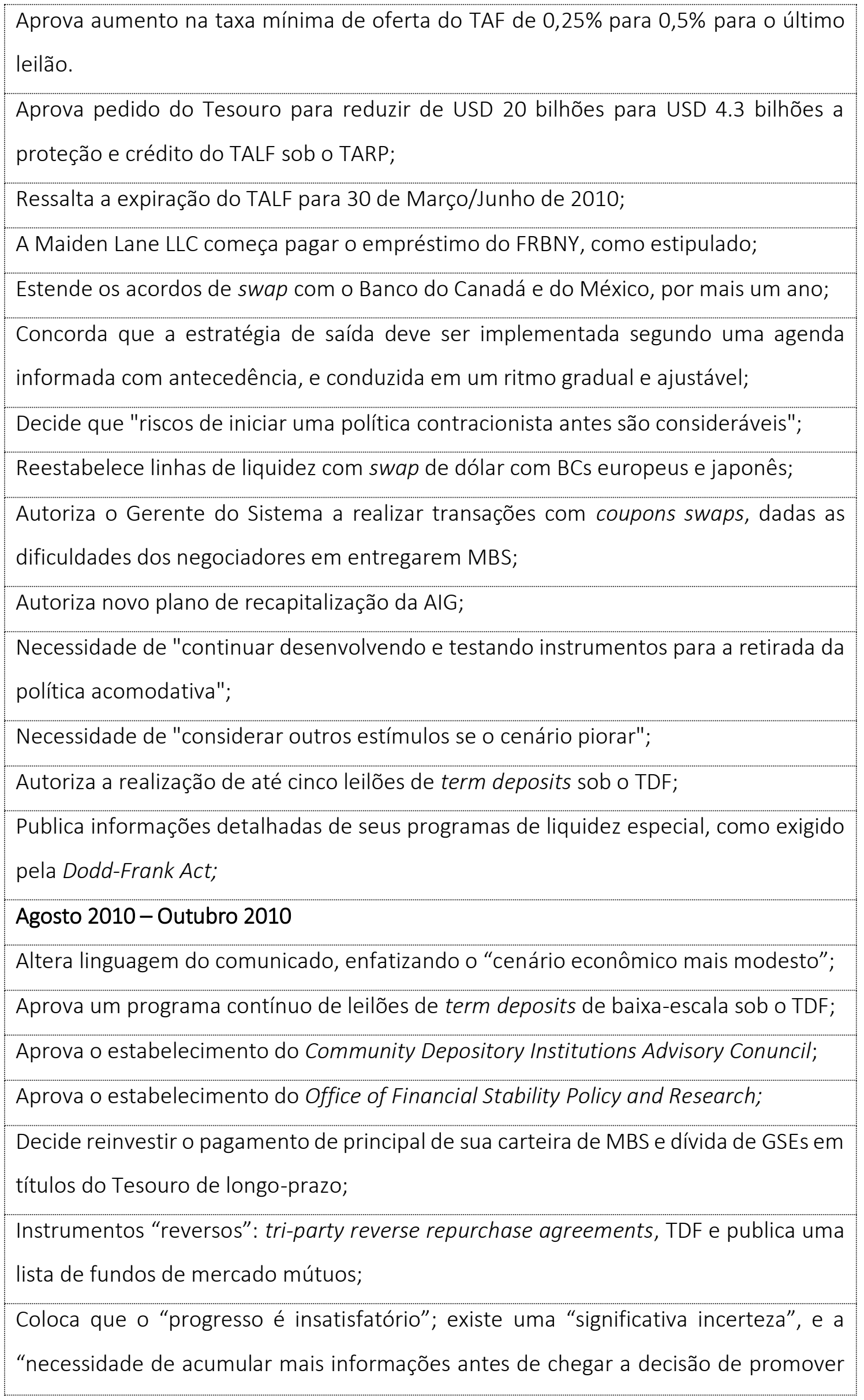


mais estímulos; preparado para prover políticas acomodativa adicionais caso necessário".

Novembro 2010 - Julho 2011

Decide expandir a carteira do FED, e comprar mais USD 600 bilhões de títulos, USD 75 bilhões por mês até o segundo trimestre de 2011;

Ajusta o comunicado para esclarecer que a taxa de desemprego estava alta e a inflação baixa;

Estende os acordos de liquidez de swap em dólar com BCs estrangeiros até 1 de Agosto de 2011;

Amplia as compras para USD 80 bilhões por mês, devido ao ritmo atual de compras;

Comunicado menciona as melhoras na atividade econômica e no mercado de trabalho, e resume o raciocínio do Comitê em relação as pressões sobre a inflação;

Subcomitê sugere ao Presidente realizar conferências regulares após as reuniões do FOMC (aquelas em que o SEP é publicado);

Estende os acordos de swap com o BC do Canadá e do México;

Começa uma venda competitiva de MBS residencial (não de agências) pelo Maiden Lane II LLC, após o Tesouro anunciar que começaria a vender sua carteira de MBS de GSEs.

AIG paga o crédito recebido do FED pelas SPVs AIA e ALICO;

Comunicado indica que a recuperação continuava e o mercado de trabalho estava progredindo, assim como, inclui um resumo do raciocínio do Comitê em relação as pressões sobre a inflação;

Elabora princípios estratégicos para a saída, em relação às políticas acomodativas;

Comunicado faz referência a inflação para esclarecer os objetivos do Comitê;

Agosto de 2011

Participantes da reunião ressaltam a "piora da perspectiva da economia e necessidade de resposta do FED";

Decide fortalecer a orientação do FOMC sobre a taxa de juros, sendo mais explícito sobre o período: nível excepcionalmente baixo pelo menos até a metade de 2013; 
Comunicado reconhece que a recuperação era lenta e que instrumentos seriam empregados quando apropriado;

Quadro A-1 - Ações e decisões do Federal Reserve System (FED).

\section{Setembro de 2008}

Coloca as GSEs em processo de recuperação, usando três programas diferentes:

PSPAs, GSE Credit Facility e GSE Mortgage-backed securities program;

Secretário, junto com presidente do FED e da SEC, apresenta proposta de legislação

(TARP) ao Congresso;

Anúncio de expansão do programa existente de compra de MBS de GSEs;

Anúncio do Temporary Guarantee Program for Money Market Mutual Funds.

\section{Outubro de 2008}

Assinado o Emergency Economic Stabilization Act of 2008 (EESA);

FED anuncia ajuda de USD 85 bilhões ao AIG, com apoio do Tesouro;

Criado o CPP

\section{Novembro de 2008}

Reestruturação do programa de crédito da AIG, com mais USD 40 bilhões;

Anúncio do TALF, programa do FED e do Tesouro;

Anúncio do AGP.

\section{Dezembro de 2008}

Cria programa TIP e compra USD 20 bilhões em ações do Citigroup;

Cria o AIFP, emprestando USD 76 bilhões para a GM e a Chrysler.

\section{Janeiro de 2009}

Usa o TIP para comprar USD 20 bilhões em ações do Bank of America (BofA);

Garante USD 5 bilhões em perdas potenciais em empréstimos para o Citigroup,

envolvendo também o FDIC e o FED;

Anuncia com o FED e o FDIC acordo para dividir perdas potenciais de USD 118

bilhões do BofA;

Sob o AIFP, a GM recebe mais USD 5.4 bilhões;

Sob o AIFP, empresta a Chrysler mais USD 4 bilhões e mais tarde, mais USD 1.5 bilhão; 


\begin{tabular}{|c|}
\hline Fevereiro de 2009 \\
\hline Sob o AlFP, libera mais USD 4 bilhões para a GM; \\
\hline $\begin{array}{l}\text { Anúncio de novos programas e reformulação de outros, com a maioria baseada no } \\
\text { TARP; }\end{array}$ \\
\hline Criação do PPIP, \\
\hline Assinado o American Recovery and Reinvestment Act of 2009 (ARRA), \\
\hline $\begin{array}{l}\text { Anunciado o HAMP, programa com USD } 50 \text { bilhões do TARP para refinanciar } \\
\text { hipotecas; }\end{array}$ \\
\hline Aumenta de USD 100 para USD 200 bilhões o limite para os PSPAs de GSEs; \\
\hline Março de 2009 \\
\hline Reduz os fundos para o CPP, de USD 250 para USD 218 bilhões; \\
\hline $\begin{array}{l}\text { Anúncio do Unlocking Credit for Small Business Initiative para aumentar os } \\
\text { empréstimos a pequenas empresas, com USD } 15 \text { bilhões do TARP. }\end{array}$ \\
\hline Sob o AlFP, cria o Auto Supplier Support Program; \\
\hline Também sob o AlFP, estabeleceu o Warranty Commitment Program; \\
\hline Abril de 2009 \\
\hline $\begin{array}{l}\text { Sob o AIFP e o Auto Supplier Support Program, compromete USD } 5 \text { bilhões em } \\
\text { financiamentos para a GM e Chrysler, reduzidos em seguida para USD } 3.5 \text { bilhões; }\end{array}$ \\
\hline $\begin{array}{l}\text { Sob o AIFP e o Auto Supplier Support Program, empresta USD } 280 \text { milhões para a } \\
\text { Chrysler e USD } 360 \text { para a GM (empresas de propósito especial); }\end{array}$ \\
\hline $\begin{array}{l}\text { Sob o AIFP, revisa o acordo da GM para aumentar o limite de empréstimo de USD } \\
13.4 \text { bilhões para USD } 15.4 \text { bilhões; }\end{array}$ \\
\hline Chrysler pede falência, formando nova entidade, NewChrysler; \\
\hline Reestruturação do programa de investimento da AIG. \\
\hline Maio de 2009 \\
\hline $\begin{array}{l}\text { Junto com o FED e o FDIC publica o SCAP com o resultado dos testes de estresse em } \\
\text { bancos; }\end{array}$ \\
\hline $\begin{array}{l}\text { Sob o AIFP, revê o acordo com a GM para aumentar o limite de empréstimo de USD } \\
15.4 \text { bilhões para USD } 19.4 \text { bilhões; }\end{array}$ \\
\hline $\begin{array}{l}\text { BofA notificou Tesouro, FDIC e FED seu desejo de interromper as negociações sob o } \\
\text { AGP; }\end{array}$ \\
\hline
\end{tabular}


Promulgadas as leis Helping Families Save Their Homes Act of 2009 e HCTC - tax credit increase.

\section{Junho 2009 - Setembro 2009}

GM pede falência, formando nova entidade, GM NewCo;

Apresenta proposta legislativa de reforma financeira regulatória;

Revisão de acordo com o Citigroup, sob o CPP;

Extingue o Auto Supplier Support Program, sob o AIFP;

Sob o AIFP, Chrysler paga todo o empréstimo;

Sob o AIFP, publica proposta de investimento de USD 13.4 bilhões na GM (investiu metade);

Foi encerrado o Temporary Guarantee Program for Money Market Mutual Funds;

Até esta data, o Tesouro comprou USD 192 bilhões em MBS de GSEs e mais USD 5

bilhões pelo GSE MBS Purchase Program;

\section{Novembro 2009 - Dezembro 2009}

AIG não realizou o pagamento de dividendos;

O programa TALF é estendido até 31 de Março/Junho de 2010.

Secretário notificou o Congresso da extensão do TARP, até 3 de Outubro de 2010;

Tesouro começa a leiloar garantias do CPP de bancos que decidiram não recompralas;

É encerrado do GSE Credit Facility, sem ter efetuado nenhum desembolso;

A autoridade do Tesouro sob o HERA expira.

Fevereiro 2010 - Março 2010

Criado o Housing Finance Agency Innovation Fund for the Hardest Hit Housing

Markets (HHF), para desenhar programas para retomar propriedades, com verba de USD 7.6 bilhões;

Anúncio do Community Development Capital Initiative (CDCl), providenciando capital de baixo custo para bancos comunitários;

Implementação do SBA7(a) Security Purchase Program, sob o Unlocking Credit for Small Business Initiative; 
Patient Protection and Affordable Care Act (ACA), maior revisão de leis de impostos em 20 anos e Health Care and Education Reconciliation Act of 2010, com emendas ao primeiro pacote.

\section{Abril 2010 - Julho 2010}

Aponta dois diretores para o conselho da AIG, devido ao não pagamento de dividendos;

Começa o processo de venda de ações do Citigroup;

TALF parou de conceder novos empréstimos e redução do compromisso do Tesouro para USD 4.3 bilhões;

Assinada a Dodd-Frank Wall Street Reform and Consumer Protection Act of 2010 (Dodd-Frank Act), reduzindo a autoridade do TARP para USD 475 bilhões.

\section{Setembro 2010 - Novembro 2010}

Lei Small Business Act (SBA) é aprovada, sendo o Tesouro responsável por USD 30 bilhões para fortalecer pequenas empresas a criarem empregos;

Revisão do custo do TARP;

Criação do HFA New Issue Bond Purchase Program (NIBP), que comprou USD 15.3

bilhões em ativos emitidos por GSEs;

Criação do HFA Temporary Credit and Liquidity Program, que comprou USD 8.2 bilhões em obrigações de HFAs;

FED e AIG anunciam planos de reestruturação dos investimentos federais.

Dezembro 2010 - Março 2011

TARP é encerrado;

Tesouro vende todas as suas ações do Citigroup, gerando proventos de USD 15.8 bilhões;

Tesouro vende todas as suas garantias do Citigroup, sob o CPP, recebendo USD 55 milhões;

Reestruturação da AIG, chegando os investimentos em ações a um total de 92,1\% da empresa.

Apresenta plano para eliminar progressivamente as GSEs e reformar o sistema de financiamento imobiliário.

Anuncia a venda de seu portfólio de MBS, sob o GSE MBS Purchase Program; 


Anuncia que o TARP oficialmente rendeu lucro.
Maio 2011 - Agosto 2011
Chrysler paga todos os empréstimos, 6 anos antes;
Modificação no Programa CPP, permitindo refinanciamento (redução do custo em
USD 1 bilhão);
Invoca autoridade legal para evitar exceder o limite da dívida.
Reestruturação dos investimentos na AIG, vendendo ações por USD 5.8 bilhões.
Agosto e Setembro de 2011
Assinado o Budget Control Act of 2011
Desembolsa fundos para o SBLF;
Fechamento do programa TIP (Citigroup e BofA).

Quadro A-2 - Ações e decisões do Departamento do Tesouro dos Estados Unidos. 
APÊNDICE B - Principais fatos e eventos entre o segundo semestre de 2008 e primeiro semestre de 2011.

\begin{tabular}{|c|}
\hline 2 Semestre de 2008 \\
\hline Falência do IndyMac Federal Bank, grande instituição de poupança. \\
\hline Aprovação do Housing and Economic Recorvery Act (HERA). \\
\hline Nacionalização das GSEs, Fannie Mae e Freddie Mac. \\
\hline Falência do Lehman Brothers, grande banco de investimentos. \\
\hline $\begin{array}{l}\text { Breaking the Buck: valor líquido dos ativos de grande fundo do mercado monetário } \\
\text { atingiu menos de USD } 1 \text { dólar por ação. }\end{array}$ \\
\hline Assistência do governo à AlG. \\
\hline $\begin{array}{l}\text { Consórcio reunindo os } 10 \text { maiores bancos do país anunciou a criação de um } \\
\text { mecanismo de liquidez que permitiria aos participantes realizar empréstimos } \\
\text { garantidos. }\end{array}$ \\
\hline $\begin{array}{l}\text { O Morgan Stanley e o Goldman Sachs, dois grandes bancos de investimento, foram } \\
\text { convertidos em banking holding companies (BHC) pelo FED, para obter acesso aos } \\
\text { programas de financiamento do banco central. }\end{array}$ \\
\hline Aquisição do Merril Lynch pelo Bank of America. \\
\hline $\begin{array}{l}\text { Washington Mutual e Wachovia, dois bancos de investimentos, passam por } \\
\text { dificuldades. O WaMu encerra as suas atividades e o Wachovia é adquirido pela Wells } \\
\text { Fargo. }\end{array}$ \\
\hline FDIC anuncia a extensão de garantias as instituições bancárias, sob o programa TLGP. \\
\hline Diversas instituições bancárias faliram ou foram adquiridas por concorrentes. \\
\hline Conferência do G-20 em Washington. \\
\hline Assistência ao Citigroup. \\
\hline Proposta do TARP é rejeitada pelo Congresso. \\
\hline $\begin{array}{l}\text { Aprovação do Emergency Economic Stabilization Act (EESA), com recursos para o } \\
\text { TARP. }\end{array}$ \\
\hline $\begin{array}{l}\text { Bancos estrangeiros parcialmente ou totalmente nacionalizados: Bradford and } \\
\text { Bingley, Fortis e Dexia. A Hypo Real Estate Holding AG recebeu uma grande injeção } \\
\text { de capital do governo alemão. }\end{array}$ \\
\hline
\end{tabular}


O FED e cinco outros bancos centrais reduziram as suas taxas de juros em ação coordenada. Diversos bancos centrais estrangeiros de economias avançadas, assim como o FED, anunciaram uma série de medidas extraordinárias para enfrentar a turbulência financeira, a desaceleração da atividade econômica e a redução das pressões inflacionárias. Em virtude desse cenário econômico, muitas economias emergentes também implementaram políticas fiscais e monetárias expansionistas.

Obama é eleito o próximo presidente dos Estados Unidos.

National Bureau of Economic Analysis (NBER) anuncia que a economia estava em recessão desde dezembro de 2007.

\section{Ano de 2009}

Assistência ao Bank of America.

Lançamento e expansão do TALF.

Anúncio do Financial Stability Plan (FSP).

Reestruturação da assistência ao AIG.

Conferência do G-20 em Londres.

Anúncio do ECB de compra de ativos.

Fim oficial da recessão.

Assinatura do The Credit Card Accountability, Responsability, and Disclosure Act

Assinatura do The Helping Families Save Their Homes Act

Publicação do SCAP.

Países da periferia da Europa continuavam enfrentando intensa turbulência financeira, e receberam apoio do FMI (por causa de desequilíbrios externos e dependência a fluxo de capitais estrangeiros).

Conferência do G-20 em Pittsburgh.

Ano de 2010

Crise na Grécia e anúncio de plano de consolidação fiscal.

Aumentam as pressões acerca da situação fiscal de outros países da periferia da Europa.

Preocupações sobre implicações do cenário europeu sobre a economia mundial (recuperação norte-americana e desaceleração da China).

Teto da dívida norte-americana é elevado. 


\begin{tabular}{|c|}
\hline A EU e o FMI anunciam pacote de USD 110 bilhões para a Grécia. \\
\hline $\begin{array}{l}\text { Autoridades européias anunciam amplas medidas de estabilização, com } 60 \text { bilhões de } \\
\text { euros do Mecanismo de Estabilização Financeira e } 440 \text { bilhões de euros de uma SPV, } \\
\text { Programa de Estabilização Financeira Europeu. }\end{array}$ \\
\hline Moody's rebaixa o status da dívida da Grécia para grau especulativo. \\
\hline $\begin{array}{l}\text { União Européia anuncia o estabelecimento de uma estrutura para prover ajuda } \\
\text { financeira a governos da zona do euro e a intenção do ECB em comprar dívidas } \\
\text { soberanas. }\end{array}$ \\
\hline $\begin{array}{l}\text { Autoridades chinesas aumentaram a necessidade de reservas bancárias e anunciaram } \\
\text { mais tarde que tomariam medidas para aumentar a flexibilidade do renmimbi. }\end{array}$ \\
\hline $\begin{array}{l}\text { BEA revisa os dados de 2007-09 e mostrou que a recessão foi mais profunda que o } \\
\text { pensado, com um nível real de PIB no final de } 2009 \text { bem mais baixo que o estimado } \\
\text { anteriormente. }\end{array}$ \\
\hline $\begin{array}{l}\text { O Ministro das Finanças japonês interveio no mercado de moedas quando o yen } \\
\text { atingiu a sua maior alta contra o dólar em } 15 \text { anos. }\end{array}$ \\
\hline $\begin{array}{l}\text { Banco do Japão reduz sua taxa de juros para próximo de zero e cria novos programas } \\
\text { de liquidez. }\end{array}$ \\
\hline $\begin{array}{l}\text { Países emergentes vêem aumento no fluxo de capitais, pressionando as suas moedas. } \\
\text { Muitas autoridades intervieram nos mercados de câmbio e/ou anunciaram controle } \\
\text { de capitais. }\end{array}$ \\
\hline $\begin{array}{l}\text { Preocupações do mercado com os bancos irlandeses, muito dependentes de } \\
\text { financiamento do ECB. }\end{array}$ \\
\hline $\begin{array}{l}\text { Discussão sobre estabelecimento de um mecanismo de estabilidade financeira } \\
\text { permanente na Europa. }\end{array}$ \\
\hline Anúncio do Acordo de Basel III. \\
\hline Venda de novas casas atingiu menor nível da série histórica nos EUA. \\
\hline Conferência do G-20 em Seoul. \\
\hline $\begin{array}{l}\text { Anúncio de pacote da União Européia e FMI de } 67.5 \text { bilhões de euros para a Irlanda, } \\
\text { além de } 17.5 \text { bilhões de euros de fundos nacionais. O país concordou em estabelecer } \\
\text { medidas de austeridade adicionais. }\end{array}$ \\
\hline
\end{tabular}


Mercado passou a focar em outros países com grandes dívidas ou déficits fiscais e vulnerabilidades no sistema bancário, Portugal, Espanha, Itália e Bélgica.

BCE temporariamente adotou programa de compra de dívidas e anunciou que manteria por mais algum tempo as medidas não-convencionais de liquidez.

\section{Semestre de 2011}

O Plano de Ação para Líderes foi completado na Conferência do G-20 em Cannes.

Turbulência política na região do Oriente Médio e Norte da África (MENA).

Terremoto e tsunami no Japão.

O yen atingiu a sua maior cotação contra o dólar, movimento revertido pela intervenção coordenada no câmbio pelos ministros das finanças e presidentes dos bancos centrais do G-7.

Interrupção no fornecimento de peças japonesas para a indústrica automobilísta.

Tensão financeira e discal sobre a Grécia, Portugal e Irlanda, e agências de crédito rebaixam a nota dos títulos de dívidas desses países.

Anúncio de pacote de resgate da União Européia e FMI de 78 bilhões de euros para Portugal.

Moody's reduz a nota de crédito de Portugal para grau especulativo.

Grécia aprova novo pacote de austeridade e privatizações após início de discussões com autoridades européias de reestruturação da dívida do país.

Dados apontavam que a recuperação nos EUA estava mais lenta que o previsto.

Taxas de hipotecas permanecem em níveis baixos historicamente.

Incertezas relacionadas as discussões políticas para o aumento do teto da dívida do governo.

Agências de crédito ameaçam rebaixar a note de crédito dos EUA, devido ao risco de default.

S\&P coloca a perspectiva para a dívida federal do governo dos EUA de longo-prazo para negativa.

Sinais de estresse em algumas instituições financeiras européias, potencialmente expostas às dívidas de países periféricos.

Autoridades chinesas aumentam novamente a necessidade de reservas bancárias e permitem nova apreciação do renmimbi. 
Assinatura da lei autorizando o aumento do teto da dívida e o corte no déficit do orçamento federal.

S\&P reduz a nota da dívida soberana de longo-prazo dos EUA.

Quadro B-1 - Principais fatos e eventos entre o segundo semestre de 2008 e primeiro semestre de 2011. 